$$
496050428
$$

\title{
Determination of the Radioactive Material and Plutonium Holdup in Ducts and Piping in the 325 Building
}

D. L. Haggard

J. E. Tanner

P. L. Tomeraasen

August 1996

Prepared for

the U.S. Department of Energy

under Contract DE-AC06-76RLO 1830

Pacific Northwest National Laboratory

Operated for the U.S. Department of Energy

by Battelle

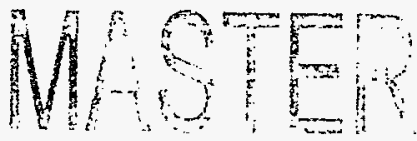




\title{
DISCLAIMER
}

This report was prepared as an account of work sponsored by an agency of the United States Government. Neither the United States Government nor any agency thereof, nor Battelle Memorial Institute, nor any of their employees, makes any warranty, express or implied, or assumes any legal liability or responsibility for the accuracy, completeness, or usefulness of any information, apparatus, product, or process disclosed, or represents that its use would not infringe privately owned rights. Reference herein to any specific commercial product, process, or service by trade name, trademark. manufacturer, or otherwise does not necessarily constitute or imply its endorsement, recommendation, or favoring by the United States Government or any agency thereof, or Battelle Memorial Institute. The views and opinions of authors expressed herein do not necessarily state or reflect those of the United States Government or any agency thereof.

\author{
PACIFIC NORTHWEST NATIONAL LABORATORY \\ operated by \\ BATTELLE \\ for the \\ UNITED STATES DEPARTMENT OF ENERGY \\ under Contract DE-ACO6-76RLO 1830
}




\section{DISCLAIMER}

Portions of this document may be illegible in electronic image products. Images are produced from the best available original document. 


\section{Executive Summary}

This report describes the measurements performed to determine the radionuclide content and mass of plutonium in exposed ducts, filters, and piping in the 325 Building at the U.S. Department of Energy Hanford Site in Washington State. This information is needed to characterize facility radiation levels, to verify compliance with criticality safety specifications, and to allow more accurate nuclear material control using nondestructive assay (NDA) methods. Gamma assay techniques typically employed for NDA analysis were used to determine the gamma-emitting isotopes in the ducts, filters, and piping. Passive neutron counting was selected to estimate the plutonium content because high gamma levels from fission and activation products effectively mask any gamma emissions from plutonium. A high-purity germanium detector was used to measure the mixed fission and activation radionuclides. A neutron slab detector containing five ${ }^{3} \mathrm{He}$ proportional counters was used to determine the neutron emission rates and estimate the mass of plutonium present. Both measurement systems followed the methods and procedures routinely used for nuclear waste assay and safeguards measurements.

The chronological order of events included a review of previously published documents on holdup assays at other sites and reviews of standards and regulatory guidelines relating to holdup and holdup measurement techniques. Reviews of facility historical radiation survey reports and discussions with facility personnel significantly helped in identifying potential holdup areas. A radiological survey mapping of the pipes and ductwork was performed prior to the actual holdup measurements. During this activity, NDA measurement locations were identified and permanently marked, and a unique naming protocol was established. This work was conducted in February 1996.

The fission and activation product inventories in the ducts and piping were measured using gamma-ray NDA techniques. A well-shielded and collimated gamma detector was used to view specific locations on the ducts and piping. The intrinsic germanium detector was used to measure the characteristic gamma-ray spectra of the fission and activation products in the 325 Building. From the gamma-ray intensities measured and the decay scheme of identified radionuclides, it is possible to obtain reasonably accurate measurements of the activity of gamma-emitting nuclides. Almost all the gamma activity present originates from the fission product ${ }^{137} \mathrm{Cs}$ and the activation product ${ }^{60} \mathrm{Co}$. Radiations from other nuclides present were effectively masked by the intense gamma rays from the mixed fission and activation products. This was particularly true in attempting to directly measure for transuranic (TRU) materials. The small quiantities of plutonium present did not produce sufficient gamma activity to be detected in the presence of so much fission and activation product activity. Transuranic activity was determined by measuring neutrons using $\mathrm{a}^{3} \mathrm{He}$ neutron detector. The fast neutrons emitted by plutonium are highly penetrating in metals and can easily be detected, even for gram quantities of plutonium surrounded by several inches of steel shielding.

Special data analysis techniques had to be used to estimate the plutonium content of the ducts since they were not in a standard counting geometry. The mass estimates may be too high if there is a significant number of neutrons produced by alpha-neutron interactions with low-atomic-number materials in the ducts and pipes, particularly alpha-emitters in intimate contact with fluorine, aluminum, boron, or beryllium. 
beryllium. This is of concern if the high-efficiency particulate air (HEPA) filters contain finely divided plutonium oxide powder on borosilicate glass filter media. To be conservative, yet realistic, the neutron - detector was calibrated using a known mass of weapons-grade plutonium (6 weight percent ${ }^{240} \mathrm{Pu}$ ) in the form of an oxide. This source was well characterized by previous NDA measurements to verify its mass.

The estimates of plutonium mass are highly dependent on the assumptions made in analyzing the data. Specifically, the estimates depend on the isotopic and chemical form of the plutonium, the distribution of plutonium, the amount of intervening shielding surrounding the plutonium, and the general neutron background in the surrounding areas. Assumptions are that the plutonium is in the form of weapons-grade plutonium oxide and at least 10 years old. This is a conservative assumption because much of the plutonium processed in the 325 Building is in the form of higher-burn-up material that emits more neutrons per gram (hence, the mass would be less for the same neutron emission rate).

Estimated plutonium mass gram equivalents in the basement ductwork and filters are 31 grams. The radioactive liquid waste system (RLWS) line has 12 grams. The laboratory vacuum system (LVS) has 2 grams equivalent plutonium. RPS has 3 grams equivalent plutonium. Total plutonium mass holdup estimates for basement areas range from 48 grams, assuming that the plutonium is weapons-grade plutonium, to a best estimate of 27 grams plutonium, assuming $11 \%{ }^{240} \mathrm{Pu}$. Estimated plutonium mass gram equivalents for all laboratories range from 385 to 581 grams. Individual laboratory estimates are listed in chapter 5.

Total estimated plutonium gram equivalent holdup and material in process for the facility is 410 grams.

In summary, the results of this survey indicate that no significant levels of plutonium, from a criticality safety perspective, reside in the ductwork, laboratory vacuum system lines, RLWS pipes, or any one laboratory in the 325 Building. 


\section{Acronyms}

DOE U.S. Department of Energy

EBR-II Experimental Breeder Reactor

FFTF Fast Flux Test Facility

HPGe high-purity germanium detector

LLNL Lawrence Livermore National Laboratory

MCA multichannel analyzer

$\mathrm{NDA}^{\circ} \quad$ nondestructive assay.

NIST National Institute of Standards and Technology

PNNL Pacific Northwest National Laboratory

RAM radioactive material

RLWS radioactive liquid waste system

RPS retention process sewer

SNM special nuclear materials

TRU transuranic 



\section{Contents}

Executive Summary $\ldots \ldots \ldots \ldots \ldots \ldots \ldots \ldots \ldots \ldots \ldots \ldots \ldots \ldots \ldots$

Acronyms $\ldots \ldots \ldots \ldots \ldots \ldots \ldots \ldots \ldots \ldots \ldots \ldots \ldots \ldots \ldots \ldots \ldots \ldots$

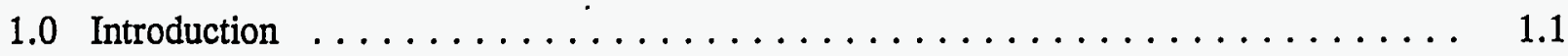

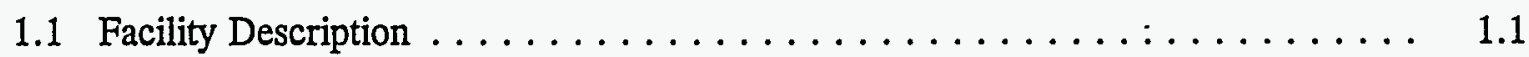

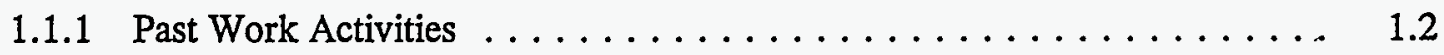

1.1.2 Present and Future Work Activities $\ldots \ldots \ldots \ldots \ldots \ldots \ldots \ldots$

1.1.3 Possible Problem Areas $\ldots \ldots \ldots \ldots \ldots \ldots \ldots \ldots \ldots \ldots \ldots$

1.2 Radiological Survey $\ldots \ldots \ldots \ldots \ldots \ldots \ldots \ldots \ldots \ldots \ldots \ldots \ldots$

1.2.1 Radiological Survey Equipment $\ldots \ldots \ldots \ldots \ldots \ldots \ldots \ldots$

1.2.2 Delineation of Assay Sites Procedure $\ldots \ldots \ldots \ldots \ldots \ldots \ldots$

1.3 Gamma Assay $\ldots \ldots \ldots \ldots \ldots \ldots \ldots \ldots \ldots \ldots \ldots \ldots$

1.3.1 Point Source Calibrations . . . . . . . . . . . . . . . 1.10

1.3.2 Line Source Calibrations $\ldots \ldots \ldots \ldots \ldots \ldots \ldots \ldots \ldots \ldots \ldots \ldots$

1.3.3 Area Source Calibrations . . . . . . . . . . . . . . . . 1.11

1.4 Neutron Assay $\ldots \ldots \ldots \ldots \ldots \ldots \ldots \ldots \ldots \ldots \ldots \ldots \ldots \ldots$

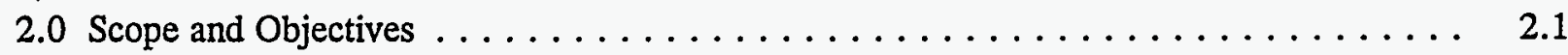

2.1 Definition of the Problem $\ldots \ldots \ldots \ldots \ldots \ldots \ldots \ldots \ldots \ldots \ldots \ldots \ldots \ldots \ldots$

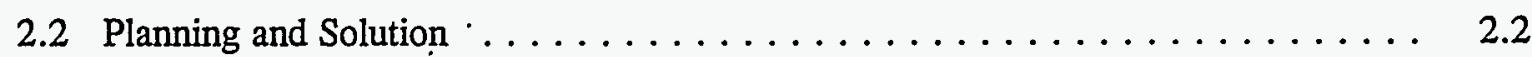

3.0 Measurements $\ldots \ldots \ldots \ldots \ldots \ldots \ldots \ldots \ldots \ldots \ldots \ldots \ldots \ldots \ldots \ldots \ldots \ldots$

3.1 Measurement and Test Equipment $\ldots \ldots \ldots \ldots \ldots \ldots \ldots \ldots \ldots \ldots \ldots$

3.2 Calibration Standards $\ldots \ldots \ldots \ldots \ldots \ldots \ldots \ldots \ldots \ldots \ldots \ldots \ldots \ldots \ldots \ldots$

3.3 Measurement and Quality Control $\ldots \ldots \ldots \ldots \ldots \ldots \ldots \ldots \ldots \ldots \ldots \ldots \ldots \ldots$ 
3.3.1 Preparations for Measurement and Test Equipment . . . . . . . . . 3.3

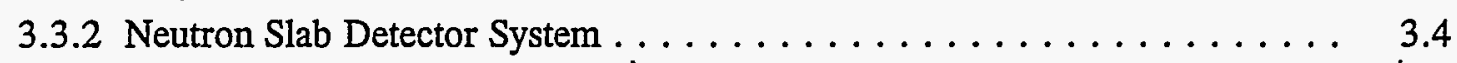

3.3 .3 Gamma Assay System . . . . . . . . . . . . . . . . . . 3.4

3.4 Pretest Verifications $\ldots \ldots \ldots \ldots \ldots \ldots \ldots \ldots \ldots \ldots \ldots \ldots \ldots \ldots$

3.4 .1 Testing of Electronics $\ldots \ldots \ldots \ldots \ldots \ldots \ldots \ldots \ldots \ldots$

3.4.2 Angular Response Measurements . . . . . . . . . . . . 3.6

3.4.3 Calibration of Slab Detector with Plutonium Oxide $\ldots \ldots \ldots \ldots \ldots$

3.5 Neutron Measurements in the 325 Building . . . . . . . . . . 3.9

3.5.1 Operational Check $\ldots \ldots \ldots \ldots \ldots \ldots \ldots \ldots \ldots \ldots \ldots \ldots$

3.5.2 Background Measurements . . . . . . . . . . . . . 3.9

4.0 Analysis of Data $\ldots \ldots \ldots \ldots \ldots \ldots \ldots \ldots \ldots \ldots \ldots \ldots \ldots \ldots \ldots \ldots$

4.1 Analysis of Calibration and Verification Measurements . . . . . . . . 4.1

4.2 Analysis of 325 Building Measurements $\ldots \ldots \ldots \ldots \ldots \ldots \ldots \ldots \ldots \ldots \ldots$

4.2.1 Basic Assumptions Used for Calculations $\ldots \ldots \ldots \ldots \ldots \ldots \ldots$

4.2 .2 Neutron Background $\ldots \ldots \ldots \ldots \ldots \ldots \ldots \ldots \ldots \ldots . \ldots \ldots$

4.2 .3 Calculated Mass of Plutonium $\ldots \ldots \ldots \ldots \ldots \ldots \ldots \ldots \ldots$

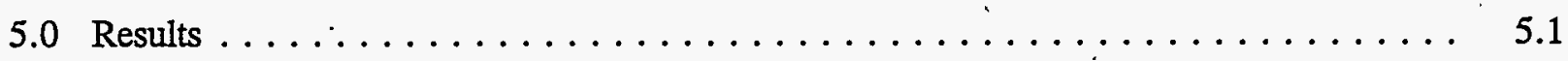

5.1 Neutron Measurement Results $\ldots \ldots \ldots \ldots \ldots \ldots \ldots \ldots \ldots \ldots \ldots$

5.2 Gamma Measurement Results. . . . . . . . . . . . . 5.1

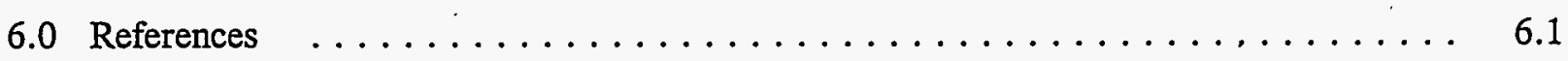

Appendix A - Basic Holdup Assay Measurements Procedure MCA-510 . . . . . . . . A.1

Appendix B - Schematics of NDA Measurement Locations $\ldots \ldots \ldots \ldots \ldots \ldots$. . . . .

Appendix C - Neutron Measurement Results $\ldots \ldots \ldots \ldots \ldots \ldots \ldots \ldots \ldots$ 


\section{Figures}

1.1 Point Source Measurements by Collimated High-Purity Germanium Detector at Selected Distances from Source $\ldots \ldots \ldots \ldots \ldots \ldots \ldots \ldots \ldots \ldots \ldots \ldots$

1.2 Distribution of Gamma-Ray Activity Along Horizontal Measurement Axis of the HPGe Detector $\ldots \ldots \ldots \ldots \ldots \ldots \ldots \ldots \ldots \ldots \ldots \ldots \ldots$

3.1 Neutron Energy Spectra from Plutonium Compounds $\ldots \ldots \ldots \ldots \ldots$

3.2 Energy Deposition Spectrum from the ${ }^{3} \mathrm{He}$ Proportional Counters Exposed to a

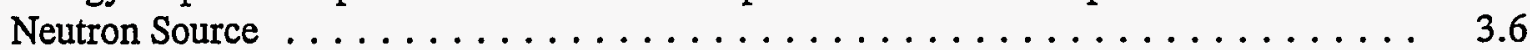

3.3 Relative Angular Response of the Slab Neutron Detector as a Function of Polar Angle ............................. 3.7

3.4 Relative Angular Response of the Slab Neutron Detector as a Function of

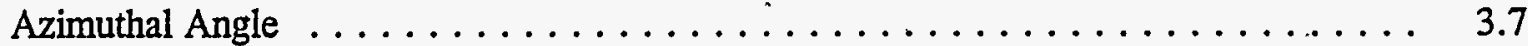

4.1 Example of Inverse Square Measurements with Neutron Slab Detector Exposed to a Plutonium Oxide Source Containing 108 Grams of Plutonium . . . . . . . . . 4.2

5.1 Cesium-137 Found in RLWS Lines, Curies $\ldots \ldots \ldots \ldots \ldots \ldots \ldots \ldots$ 


\section{Tables}

3.1 Isotopic Composition of Plutonium Ash Reference Material, Weight

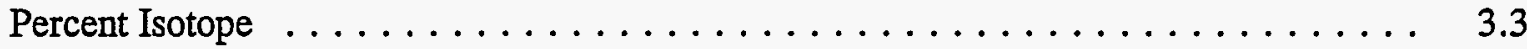

3.2 Effect of Steel and Aluminum Shielding Materials Placed Between the Plutonium and the Slab Neutron Detector $\ldots \ldots \ldots \ldots \ldots \ldots \ldots \ldots \ldots$

$5.1^{\circ}$ Plutonium Holdup in Ductwork and LVS, HEPA, RPS, and RLWS Lines in 325 Basement . . . . . . . . . . . . . . . . . . . . . . . . . 5.2

5.2 Plutonium Holdup in RLWS Pipeline in 325 Building Basement $\ldots \ldots \ldots \ldots . \ldots$

5.3 Plutonium Holdup in Laboratory Hoods and Glove Boxes $\ldots \ldots \ldots \ldots$

5.4 Summary of Plutonium Holdup in the 325 Building $\ldots \ldots \ldots \ldots \ldots \ldots$

5.5 Radionuclide Content By Direct Gamma Ray Measurement Using a Collimated High-Purity Germanium Detector, Curies $\ldots \ldots \ldots \ldots \ldots \ldots \ldots$

5.6 Radioactive Liquid Waste System Pipeline Activity Profile . . . . . . . . . . . . 5.11 


\subsection{Introduction}

This section provides a brief description of the facilities in the 325 Building to provide an overview of radionuclides that may be present in the various process equipment and ancillary ductwork and piping. The equipment and methods used to provide estimates of the radionuclide inventories are discussed briefly.

\subsection{Facility Description}

The 325 Building Applied Chemistry Laboratory is operated by the Pacific Northwest National Laboratory (PNNL) for the U.S. Department of Energy (DOE). ${ }^{\text {(a) }}$ The Applied Chemistry Laboratory is a Category II nuclear facility located within the 300 Area. Work recently performed, under way, or planned for the near future includes a variety of activities including: process research, development and demonstrations; analytic chemistry research and services; and treatment of radioactive, hazardous, or mixed radioactive and hazardous wastes. Work is divided among a variety of locations including: two hot cell complexes, glove boxes, fume hoods, and laboratory benches, depending on the radioactive or hazardous nature of the work. A single project frequently involves working in more than one of these locations, such as sample preparation or dilution in the hot cell or glove box, followed by analytical measurements in a fume hood.

The 325 Building is a concrete structure three stories high with a basement. The structure houses offices, analytical laboratories and shops, as well as a plutonium storage vault and several highly shielded hot cells with associated truck locks. A wide variety of activities involving spent nuclear fuel, separation processes, waste analysis, analytic chemistry services, etc. are conducted in the facility. The facility has contained large inventories of transuranics, fission and activation products, tritium, and radium in the past. These materials are located in the laboratory and hot cell areas in the building. The First Floor contains the offices, shops, and laboratories, as well as the 325A hot cells (High Level Radiochemistry Facility) and 325B hot cells (Shielded Analytical Lab.). The.Second Floor contains more offices, and the third Floor contains ventilation equipment and access to the top of the cells. The Basement contains more offices and laboratories as well as the storage vault and process equipment piping and ductwork for the laboratories.

Analytical services are provided for all projects in the 325 Building, as well as services for outside customers. General chemical laboratories are equipped with work space on laboratory benches and fume hoods. Large pieces of equipment, such as spectrometers, are usually placed in separate glove boxes for contamination control. Entire rooms and laboratories may be devoted exclusively to glove boxes and

(a) Pacific Northwest National Laboratory is operated by the Battelle Memorial Institute for the U.S. Department of Energy under contract DE-AC06-76RLO 1830. 
have few or no laboratory benches. However, some analytical equipment is maintained free of contamination and is housed in separate areas without any fume hoods or laboratory benches. Because of the constantly changing work requirements, the arrangement of laboratories and equipment in the laboratories is constantly changing as some projects are completed and new projects are started, or as project needs change. At the present time, 20 to 40 different projects are simultaneously conducted in the 325 Building.

\subsubsection{Past Work Activities}

In the recent past, there have been a number of activities related to the separation of plutonium from spent nuclear fuels, including separation of plutonium from high exposure fuels. Some of the typical activities that have taken place in the last few years (waste-related, fuel-related, and others) are described below

\section{Waste-Related Activities}

- Characterize chemical, radiochemical, and physical properties from Hanford single-shell and doubleshell.waste tanks. Particular emphasis is given to waste stream suitability for processing at the Hanford Waste Vitrification Plant (HWVP).

- Evaluate ion-exchange resins for the recovery of selected radionuclides from vitrification wastes produced by the HWVP.

- Develop flowsheets for processing selected Hanford wastes.

- Provide a treatment service for hazardous waste or mixed (hazardous and radioactive) waste generated at PNNL. This includes grouting, neutralization, distillation, and new and emerging technologies for chemical waste treatment and destruction of waste.

- Determine the potential for rapid exothermic reactions between ferrocyanide and nitrate or nitrite in wastes from single-shelled tanks at Hanford.

- Evaluate the performance of a resorcinol/formaldehyde ion-exchange resin for removal of ${ }^{137} \mathrm{Cs}$ from Savannah River alkaline waste.

- Develop and demonstrate a process for preparing waste sludge from West Valley Nuclear Services Company for vitrification feeds. Develop processes for secondary treatment of wash or supernatant liquids to reduce the level of radioactivity to as low as reasonably achievable (ALARA).

- Prepare organic standards and investigate organic extractions. Work may involve gallon quantities of solvents such as acetone, hexane, toluene, iso-octane, carbon tetrachloride, Freon 112, and methylene chloride. 


\section{Fuel-Related Activities}

- Develop and test flowsheets for the removal of transuranics and other selected radionuclides from dissolved fuel from light-water reactors in support of processes being developed by Westinghouse Hanford Company.

- Provide analytical chemistry support for fuels-related programs such as the Materials Characterization Center and Tuff Repository.Program.

- Prepare and analyze samples for x-ray diffraction, scanning electron microscope, or Auger electron analysis. Samples include oxidized and nonoxidized spent fuel from light-water reactors and fission product deposits from fuel rods.

- Investigate oxidation kinetics of spent light-water reactor fuel.

- Conduct Fast Flux Text Facility (FFTF) fuel analyses.

\section{Other Activities}

- Provide as-needed analyses of liquids and solids associated with the Hanford Site characterization and remediation efforts and plant operations for compliance with the Resource Conservation and Recovery Act (RCRA) and the Comprehensive Environmental Response, Compensation, and Liability Act (CERCLA).

- Analyze performance evaluation samples submitted by the EPA, the Environmental Monitoring Laboratory, and other organizations as a routine part of laboratory quality control programs.

- Prepare standard solutions of radionuclides from stock batches for research and development of analytical procedures and for quality control.

- Investigate tritium release from tritium-containing materials such as beryllium and lithium oxide. Examine releases by both carrier gas extraction and vacuum extraction.

- Study tritium permeation through reactor target rods.

- Separate and process medically useable radioisotopes.

- Recover ${ }^{238} \mathrm{Pu}$ from irradiated ${ }^{237} \mathrm{~Np}$.

\subsubsection{Present and Future Work Activities}

Recently, there has been a major effort to greatly reduce nuclear and radioactive material inventories within the 325 Building to reduce the facility from Hazard Category II to Category. III status. Material 
from old programs has been repackaged and shipped out of the building. The amount of material used in current and future programs has been severely restricted. Current and future programs include the following:

- $N$ Reactor Fuel Characterization - Most of this work is in the 327 Building, but some may take place in the 325 Building involving only a few grams of ${ }^{235} \mathrm{U}$ at a time, with a maximum of about $50 \mathrm{~g}$ of ${ }^{235} \mathrm{U}$ in the building. There will be small amounts of plutonium associated with the fuel.

- Waste Characterization Studies - There is high potential for increased work activity for waste characterization studies in the 325 Building. This will include small quantities of transuranics as well as fission products.

- Fuel Leaching/Dissolution Studies - There is ongoing work with Light Water Reactor (LWR) fuels and $\mathrm{N}$ Reactor fuels, with the possibility of Navy reactor fuel work. The amount of nuclear material involyed is small, about $0.5 \mathrm{~kg}$ for each study.

- Medical Isotope Production - Most of this work currently involves production of ${ }^{90} \mathrm{Y}$, but other isotopes may be considered in the future.

- Radium Production and Radium Repository programs - There are several radium production programs being considered for work in the 325 Building, including purification of ${ }^{223} \mathrm{Ra}$ from Fernald. The laboratory has been exploring the potential for becoming a repository for radium needles and repackaging the material for reuse. Small but significant amounts of radium have been processed in the past in the 325 Building.

- ${ }^{233} U$ Purification - There is the possibility of a limited-production demonstration of a process for separating. ${ }^{233} \mathrm{U}$ from irradiated thorium. Initial work would involve about $100 \mathrm{~g}$ of ${ }^{233} \mathrm{U}$.

- ${ }^{238} \mathrm{Pu}$ Chemistry Studies - There are about $15 \cdot \mathrm{g}$ of ${ }^{238} \mathrm{Pu}$ in the 325 Building involved in several studies. Because of its very high neutron emission rate, this could seriously impact estimated ${ }^{239} \mathrm{Pu}$ inventory estimates based on neutron counting.

- Plutonium Dissolution Studies (CEPOD) - A significant amount of material has recently been removed and shipped from the 325 and 324 Buildings, but there may be some hold-up left. There is the possibility of extended work for removing the plutonium from ash.

- ${ }^{238} \mathrm{Pu}$ Heat Sources - There is the possibility of the introduction of significant quantities of ${ }^{238} \mathrm{Pu}$ in heat sources in the near future. This could seriously impact ${ }^{239} \mathrm{Pu}$ estimation from neutron counting because of the very high neutron backgrounds.

- Strontium Capsules - There are significant quantities of strontium in the 325 Building, including encapsulated material in storage drums and material removed from B Cell. 
- Tritium - In addition to the past tritium work, there is a proposal for continuing post-irradiation. examination of tritium materials as well as further work on fusion programs.

\subsubsection{Possible Problem Areas}

As indicated from the discussions above, there are several potential problem areas that could interfere with the accurate determination of holdup of plutonium and other transuranic (TRU) materials, as well as the determination of the holdup of fission products and other non-TRU isotopes in the 325 Building. A wide variety of neutron-emitting materials may be present, including ${ }^{238} \mathrm{Pu},{ }^{244} \mathrm{Cm}$, and other isotopes with high neutron-emission rates. In areas with high neutron counts, it is necessary to make certain that the neutrons are from ${ }^{239} \mathrm{Pu}$ and associated plutonium isotopes; otherwise, erroneously high plutonium estimates will result. The isotope ${ }^{244} \mathrm{Cm}$ used in waste vitrification studies presents a serious problem because milligram quantities emit as many neutrons as kilogram quantities of plutonium. With its weak gamma . emissions, it will be difficult to accurately measure ${ }^{244} \mathrm{Cm}$ behind massive shields. It may also be necessary to perform a greater number of gamma spectra measurements to allow better determination of plutonium isotopic compositions using the gamma analysis codes. Also, any mass spectrometric data would be of use for more accurately predicting neutron emission rates and hence better mass correlations with neutron emission rates.

There are several areas that need particular attention because in the past large quantities of transuranics were processed in these areas:

- Room.604 - Plutonium was calcined in this room, and there may be significant holdup in the air ducts and waste lines in this area.

- Room 410 - In a former glove box and ancillary locations in the room, a chemist processed significant quantities of alpha-emitters, including plutonium, ${ }^{238} \mathrm{Pu},{ }^{244} \mathrm{Cm}$, and even ${ }^{252} \mathrm{Cf}$. Accurate plutonium measurements may be difficult because of interference by the other isotopes which have very high neutron emissions. Attention needs to be given to the ducts and piping in this area.

- 300 Hallway and laboratories - In the 1960s, the laboratories along the hallway and the hallway itself were contaminated with plutonium. Much of the air ducts and ventilation was replaced, but a careful survey was necessary to make certain that plutonium was not contained in sections of ducts or pipes that were not replaced:

- $325 \mathrm{~A}$ hot cells - Both ${ }^{237} \mathrm{~Np}$ and ${ }^{238} \mathrm{Pu}$ separation processes were conducted in the $325 \mathrm{~A}$ hot cells. A spill of ${ }^{238} \mathrm{Pu}$ solution in C-Cell resulted in a significant amount of contamination of the rear face of the cell. There may be enough ${ }^{237} \mathrm{~Np}$ or ${ }^{238} \mathrm{Pu}$ present to interfere with plutonium holdup estimates from neutron counting.

- Laboratory vacuum system - During an outage, the building vacuum system was pressurized by accident. There is a distinct possibility that americium was dispersed into the vacuum system lines. During the vacuum system reversal, about 1 gram of ${ }^{241} \mathrm{Am}$ was spread into laboratories on the 500 hallway. 
- 325 basement - There is a high probability that the sumps and piping in the basement below the hot cells contain spent fuel debris or transuranics from disassembly and separation processes conducted in the hot cells.

- FFTF fuels glove boxes - A chemist processed large quantities of plutonium for use in the fuel program for the FFTF. Since much of the plutonium was in the form of plutonium dioxide powder, there was a good possibility that the interior of the ducts and ventilation system and filter boxes contained significant quantities of plutonium.

- Sealed sources - An 80-g PuBe source and a $156-\mu \mathrm{g}{ }^{252} \mathrm{Cf}$ source located in Room 44 and an AmBe source stored in Room 42 contribute to a significant neutron background on the east side of the basement.

\subsection{Radiological Survey}

Holdup measurements are required in all facilities where special nuclear materials (SNM) may exist in building systems. Potential criticality safety issues have been identified at other DOE facilities and have been addressed in PNL-MA-25, Criticality Safety, as action items. ${ }^{(a)}$ The major objective of this project is to identify and quantify radioactive materials that may contain transuranic (TRU) holdup in various ducts, processes, and equipment in the 325 Building. The radiological mapping survey was used 1) to locate potential sources of radioactive materials/special nuclear materials (RAM/SNM) at specified locations; 2) to provide a baseline reference point for trend analysis on data from future measurements; 3 ) to augment ongoing radiological surveys; and 4) to provide supporting documentation regarding criticality safety and provide data for nuclear material accountability.

A radiological survey of all 325 Building cell ductwork, radioactive liquid waste system (RLWS) pipes, and laboratory vacuum system lines in the basement was conducted in February 1996. The survey readings were taken.by PNNL radiological control technicians. Guidelines for holdup assay are stated in U.S. Nuclear Regulatory Commisssion (NRC) Regulatory Guides 5.23 and $5.37(1984,1983)$ and the Los Alamos Nuclear Safeguards Training Program (LANL 1992).

\subsubsection{Radiological Survey Equipment}

Equipment used for the survey included a Geiger-Mueller (GM) counter with an extendable probe and a marking device for permanently labeling measurement locations. The potential hazards identified were possible contamination and high-dose-rate areas. Personnel safety issues were addressed and covered in the radiological work procedure specific to this work. The radiological survey procedure followed regulatory guidelines. Preliminary radiation survey measurements of the facility were used to budget the measurement time, to emphasize high-holdup areas, and to determine nondestructive assay locations.

(a) Pacific Northwest Laboratory (PNL). August 17, 1994. Criticality Safety. Controlled technical manual, PNL-MA-25, Pacific Northwest Laboratory, Richland, Washington. 


\subsubsection{Delineation of Assay Sites Procedure}

The procedure used to establish assay locations is given below.

1. In each room suspected of having material holdup, detector positions (assay sites) were chosen so that the material holdup could be measured with both the neutron slab detector and the HPGe detector, if necessary.

Each room usually contained several types of holdup areas. For example, Room 45 in the basement contained most of the exposed RLWS pipes, the vacuum system lines, and the HEPA filters for all the hoods and glove boxes in the first floor laboratories.

2. Each assay site was marked with a permanent marker to ensure reproducible assay positions.

For ducts and RLWS pipes, dose rate measurements were taken at successive 2 -ft intervals, beginning $1 \mathrm{ft}$ in from the start of the duct or pipe. Where dose rates remained constant over long sections of piping or ductwork, measurements were spaced out over larger distances but usually multiples of $2 \mathrm{ft}$. Interval points were marked and identified using permanent ink or equivalent.

"Hot spots" were also identified, surveyed, and marked. Dose rate information was recorded on a floor plan schematic provided by the task leader.

3. Each site was uniquely labeled to facilitate unambiguous reference to that site in the assay log. A labeling convention was established.

Labeling proceeded sequentially for each room, beginning with room number/letter designation followed by the interval identification number. For example, the location of the first measurement point in room 45 was 45-1. Measurements began in the basement of the 325 Building in February, 1996, and progressed to the first floor laboratories during March.

\subsection{Gamma Assay}

Gamma-ray assay is based on the activity observed from specific energy peaks detected from the isotopes present. Equipment for gamma holdup measurements consisted of the following components:

- tungsten or lead collimator

- high-purity germanium (HPGe) detector - efficiency $20 \%$

- angular response of the detector/collimator reference (see Figures 1.1 and 1.2)

- Canberra Genie-PC AIM Data Analysis and Acquisition System. 


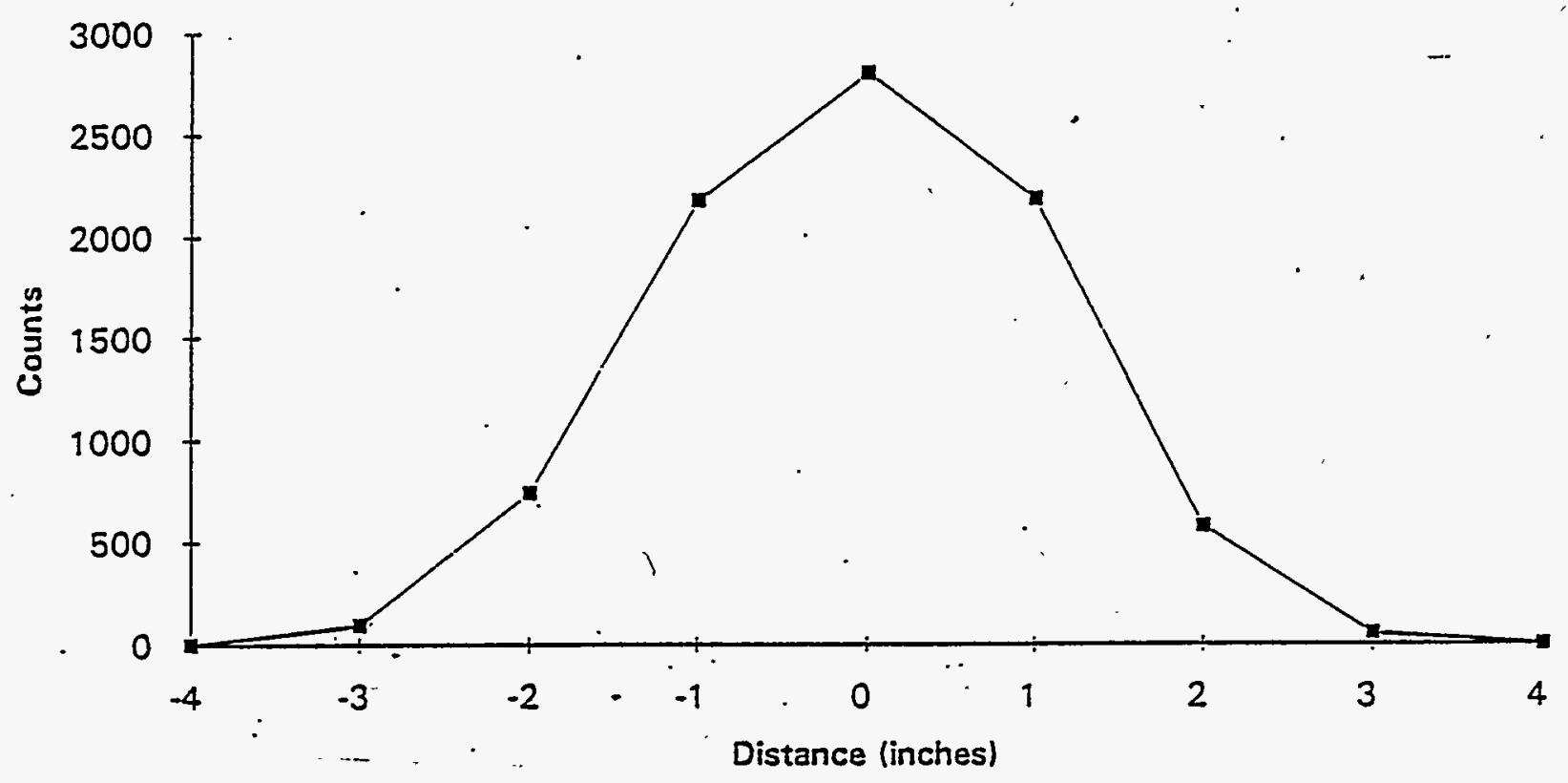

Figure 1.1. Point Source Measurements by Collimated High-Purity Germanium Detector at Selected Distances from Source

327 COLLIMATOR \#1

$12^{\prime \prime}$ FROM SOURCE

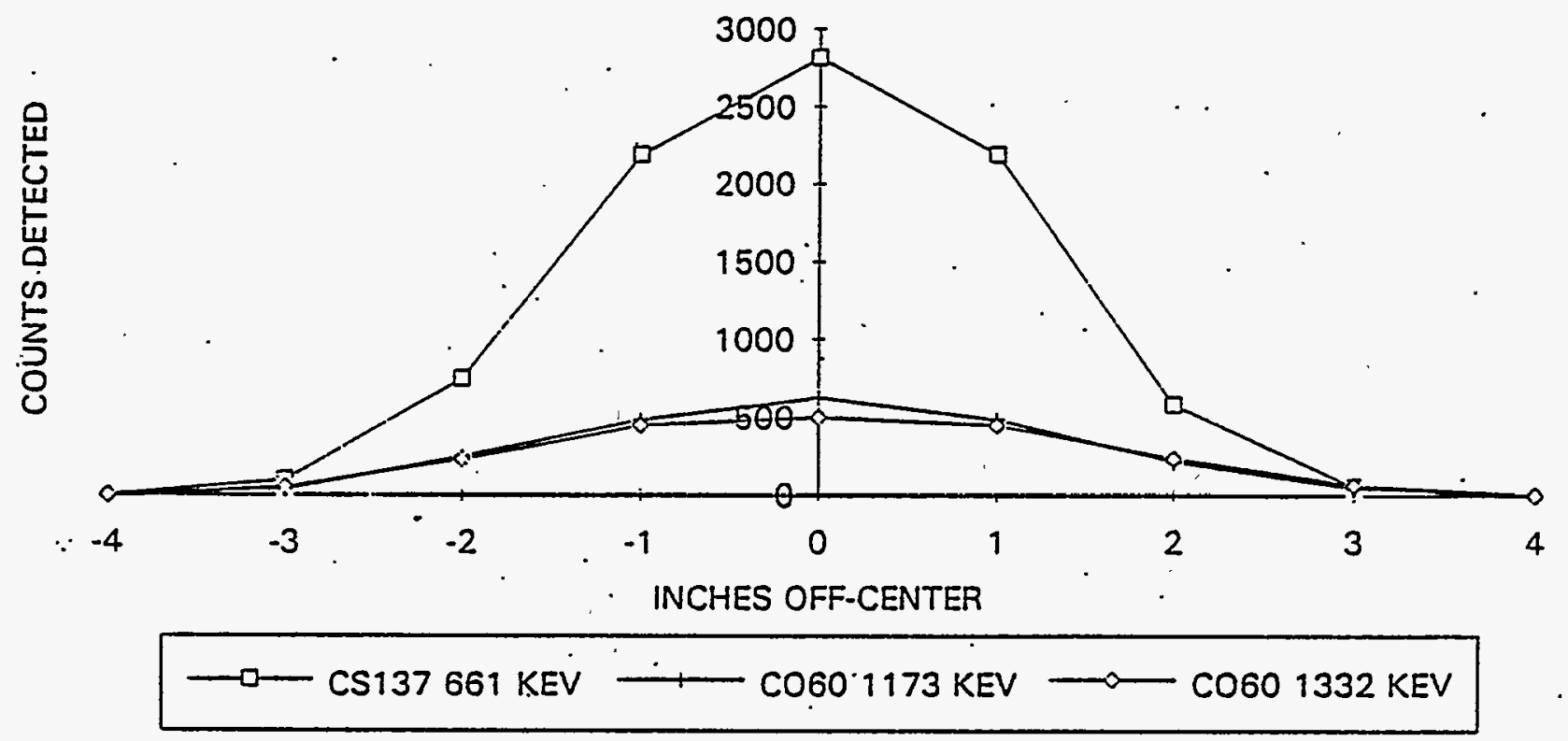

Figure 1.2. Distribution of Gamma-Ray Activity Along Horizontal Measurement Axis of the HPGe Detector 
The HPGe detector was shielded and collimated from other surrounding source material. A tungsten collimator was used with the gamma-ray detector. Additional shielding was also needed to eliminate background gamma rays originating behind the detector. The collimator provided sufficient shielding and directionality for the holdup measurement geometry. The detector's field of view was defined by the tungsten collimator. Calibration of the gamma system was performed with the same collimation setup used during the holdup measurement campaign.

Initial calibrations for the holdup measurement system were performed for point, line, and area source geometries. These point, line, and area geometry calibration constants described the distribution in the detector's field of view. The correction factors were specific to the detector and collimation setup and were used to correct for the detector's radial response to the incident radiation of interest. These corrections were used in the corresponding measurements to convert the results to activity or grams of material. This procedure used a single point source to determine these correction factors. Point source measurements were conducted at several horizontal positions, as indicated in Figure 1.1. Figure 1.2 illustrates the gamma detector's response along the horizontal measurement axis. The gamma detector's relative efficiency for that geometry was determined. One reference standard centered in front of the detector at a fixed distance was measured to determine the detector's absolute response to the incident radiation.

Formulae required to determine calibration constants are as follows:

$$
L=2 s \frac{\sum_{i=0}^{n} C_{i}}{C_{0}}-s
$$

where $L=$ effective length of the detector field of view at distance $r_{0}$

$\mathrm{s}=$ length of the horizontal increment

$C_{i}=$ net count rate at horizontal position $i$.

$\mathrm{C}_{0}=$ net count rate with the source centered in front of the detector.

$$
a_{0}=\frac{\pi s^{2}}{4}
$$

where $a_{0}$ is the incremental area at horizontal position 0

$$
a_{i}=\pi[(i+0.5) s]^{2}-\pi[(i-0.5) s]^{2}
$$

where $a_{i}$ is the incremental area at horizontal position $i$

$$
A=\frac{\sum_{i=0}^{n}\left(a_{i} C_{i}\right)}{C_{0}}
$$


where $A$ is the effective area of the detector field of view at distance $r_{0}$

$$
\begin{aligned}
& \mathrm{K}_{\mathrm{p}}=\frac{\mathrm{m}_{0}}{\mathrm{C}_{0} \mathrm{r}_{0}{ }^{2}} \\
& \mathrm{~K}_{1}=\frac{\mathrm{m}_{0}}{L C_{0} \mathrm{r}_{0}} \\
& \mathrm{~K}_{\mathrm{a}}=\frac{\mathrm{m}_{0}}{\mathrm{AC} C_{0}}
\end{aligned}
$$

where $\mathrm{K}_{\mathrm{p}}=$ point source calibration constant $\left(\mathrm{g} \cdot \mathrm{s} / \mathrm{cts} \cdot \mathrm{cm}^{2}\right)$

$\mathrm{K}_{1}=$ line source calibration constant $\left(\mathrm{g} \cdot \mathrm{s} / \mathrm{cts} \cdot \mathrm{cm}^{2}\right)$

$\mathrm{K}_{\mathrm{a}}=$ area source calibration constant $\left(\mathrm{g} \cdot \mathrm{s} / \mathrm{cts} \cdot \mathrm{cm}^{2}\right)$

$\mathrm{m}_{0}=$ mass of the reference source $(\mathrm{g})$

$\mathrm{C}_{0}=$ net count rate of the reference standard centered in front of the detector face at distance $r_{0}$ (cts/s).

Once calibration constants are determined, quantitative estimates can be made for point sources, line șources, and area sources.

\subsubsection{Point Source Calibrations}

A point source is a small deposit centered in a large detector field-of-view. Its calibration is determined with Equation 1.8:

$$
\mathrm{m}=\mathrm{K}_{\mathrm{p}} \mathrm{Cr}^{2}
$$

where $\mathrm{m}=$ mass of isotope of interest $(\mathrm{g})$

$\mathrm{K}_{\mathrm{p}}=$ point source calibration constant $\left(\mathrm{g} \cdot \mathrm{s} / \mathrm{cts} \cdot \mathrm{cm}^{2}\right)$

$\mathrm{C}=$ net count rate (cts/s)

$\mathrm{r}=$ source-to-detector distance $(\mathrm{cm})$.

\subsubsection{Line Source Calibrations}

A line source is a narrow uniform deposit, centered in a wide detector field-of-view, which spans the * width of the detector field-of-view. Its calibration is found with Equation 1.9:

$$
\mathrm{m}=\mathrm{K}_{1} \mathrm{Cr} \mathbf{l}
$$


where $\mathrm{m}=$ mass of isotope of interest $(\mathrm{g})$

$\mathrm{K}_{1}=$ line source calibration constant $\left(\mathrm{g} \cdot \mathrm{s} / \mathrm{cts} \cdot \mathrm{cm}^{2}\right)$

$\mathrm{C}=$ net count rate (cts/s)

$\mathrm{r}=$ source-to-detector distance $(\mathrm{cm})$

$\mathrm{l}=$ length of a line source $(\mathrm{cm})$.

\subsubsection{Area Source Calibrations}

An area source is a uniform deposit that fills the detector field-of-view. Its calibration is found with Equation 1.10:

$$
\mathrm{m}=\mathrm{K}_{\mathbf{a}} \mathrm{Ca}
$$

where $\mathrm{m}=$ mass of the isotope of interest $(\mathrm{g})$

$\mathrm{K}_{\mathrm{a}}=$ area source calibration constant $\left(\mathrm{g} \cdot \mathrm{s} / \mathrm{cts} \cdot \mathrm{cm}^{2}\right)$

$\mathrm{C}=$ net count rate (cts/s)

$\mathrm{a}=$ area of an area source $\left(\mathrm{cm}^{2}\right)$.

The equipment was moved to the 325 Building and checked for physical damage. A combination standard traceable to the National Institute for Standards and Technology (NIST) was measured periodically during the measurement campaign to demonstrate that the instrumentation was properly functioning and that the calibrations determined in the laboratory were still valid.

\subsection{Neutron Assay}

Accurate determination of the fissile material and radioisotope content in the ducts, filters, and piping of the 325 Building is a very difficult problem. Nondestructive assay techniques for fissile materials usually employ gamma spectroscopy to identify and quantify each gamma-emitting nuclide, such as plutonium. However, the large amounts of fission products present completely obscure any gamma rays emitted by plutonium. Fortunately, the neutrons emitted by plutonium are highly penetrating and can easily pass through several inches of the steel or lead shielding used to reduce gamma doses, although the neutrons may be degraded in energy. With some degree of uncertainty, the amount of plutonium can be determined using appropriate calibration standards and neutron detectors. Passive neutron counting is a recognized technique for nondestructive assay of plutonium and is described in Chapter 14, "Principles of Neutron Counting" in Passive Nondestructive Assay of Nuclear Materials, NUREG/CR-5550 (Reilly et al. $.1991)$.

Neutrons emitted by plutonium originate from two main sources:

- spontaneous fission of even-numbered plutonium isotopes

- alpha-neutron reactions with any low-atomic-number materials in intimate contact with the plutonium. 
Most of the neutrons originate from ${ }^{238} \mathrm{Pu},{ }^{240} \mathrm{Pu}$, and ${ }^{241} \mathrm{Am}$, which is the decay product of the shortlived nuclide ${ }^{241} \mathrm{Pu}$. Thus; it is important to know,not only the isotopic composition of the plutonium, but also the time since chemical separation of the ${ }^{241} \mathrm{Am}$ content to be able to estimate the neutron contribution from ${ }^{241} \mathrm{Am}$. In many practical situations, the number of neutrons produced by alphaneutron reactions can exceed the spontaneous fission production from plutonium. Any alpha-emitter in contact with low-atomic-number nuclides will produce neutrons. For example, transuranics that are in intimate contact with beryllium, boron, aluminum, sodium, or even concrete will produce neutrons. High neutron emission rates can result from finely divided plutonium oxide dust on borosilicate glass or aluminum spacers in HEPA filters. The neutron emission rates can be tens to hundreds of times higher than for pure plutonium metal.

It is conceivable, although not likely, that the material may not contain any plutonium, but will still emit neutrons from alpha-neutron reactions from americium or other transuranic material with high alpha activity. The exact amount of plutonium present can be determined from the neutron measurements if we know the following:

- the exact isotopic composition of the plutonium

- the time since chemical separation to allow calculation of ${ }^{241} \mathrm{Am}$ progeny

- chemical composition of the plutonium

- presence of low-atomic-number impurities in contact with alpha-emitters

- other transuranics present that may also emit neutrons, such as ${ }^{244} \mathrm{Cm}$.

We can make some simplifying assumptions that will limit the range of calculated values of the amount of plutonium that may be present. For instance, we can assume that the plutonium will be lowexposure plutonium. Neutron emission rates of weapons grade (less than $6 \%{ }^{240} \mathrm{Pu}$ ) or $\mathrm{N}$-Reactor plutonium are quite low, typically about 150 neutrons per second per gram of plutonium. Higher-exposure plutonium would emit more neutrons and result in a smaller actual mass for a given measured neutron emission rate.

Plutonium metal is chemically unstable, and any small pieces would eventually convert into an oxide or oxide-hydroxide mixture in moist air. The oxide is the most chemically stable form of plutonium and would be the most likely form to be found. The neutron emission rates of oxylates, nitrates, and hydroxide mixtures will be somewhat similar to that from pure plutonium oxide. Assuming any plutonium present would be in the form of an oxide will result in conservative estimations. Any other chemical form, particularly fluorides, would emit more neutrons and result in a smaller actual mass for a given measured neutron emission rate. However, oxides are the most probable chemical form found in reactor spent fuel. 


\subsection{Scope and Objectives}

The objectives of this work are threefold:

- provide a baseline radiological survey of the ducts and piping

- determine an upper limit of plutonium inventory and an estimate of the most probable amount of plutonium that may be present

- locate and quantify the amount of fission product, activation, and TRU materials that are present in ducts, RLWS lines and other facility processes, as a baseline for future reference.

This work is limited in scope to the nondestructive assay of the contents of the ducts, filters, and piping in the 325 Building and low-level waste that resided in those locations at the time measurements were taken.

\subsection{Definition of the Problem}

Over many years of operation of the 325 Building, the internal ducts, filter boxes, and piping and drain lines from the hot cells and laboratories have become contaminated with large amounts of fission and activation products and small amounts of plutonium and other transuranic nuclides. The fission and activation product inventory is large enough in some locations that it presents a radiation hazard, and in some locations steel and lead shielding have been added to critical areas to reduce radiation doses. It is conceivable that enough plutonium and transuranic material has accumulated to be of concern for criticality safety and safeguards controls.

The purpose of this work is to attempt to quantify the amounts of radionuclides in the internal ducts, filter boxes, and pipes leading from the hot cells. Of particular concern are the liquid waste lines that may have accumulated fuel debris, with the potential build-up of quantities of plutonium. Because of its high activity, the radioactive cesium and cobalt are relatively easy to locate. However, the high gamma levels will mask the gamma emissions from plutonium and other transuranics. The problem is further exacerbated by the streaming of neutrons down ducts and openings from the hot cells. Inventories of plutonium, curium, and other neutron-emitting nuclides in the hot cells will create variable backgrounds in the basement in the areas around the ducts and pipes. It is extremely difficult to accurately assess plutonium inventories in the presence of variable neutron backgrounds. Passive neutron measurements are further complicated by the storage of over $500 \mathrm{~g}$ of ${ }^{238} \mathrm{Pu}$ oxide stored in Room 52 in the basement of the 325 Building. The neutron emission rate from the ${ }^{238} \mathrm{Pu}$ oxide is orders of magnitude higher than from other sources we are attempting to measure. 


\subsection{Planning and Solution}

A review of the radiological conditions was made, including gamma surveys to determine hot spots in the ducts and piping. Excessive gamma dose rates from fission products preclude the use of gamma assay equipment routinely used to determine plutonium mass. The high dose rates from fission products would interfere with the plutonium isotopic analysis. Therefore, neutron assay techniques would be more reliable for locating and quantifying fissile material. A neutron slab detector based on a design from the Los Alamos National Laboratory (LLNL) Safeguards Assay Group was selected for measurements to determine the amount of plutonium that could be present. The amount of plutonium in the ducts and RLWS pipes can be estimated by:

- calibrating the neutron detector with appropriate calibration standards

- measuring the neutron flux around the ducts, filter boxes, and piping

- carefully analyzing the data to relate the measured neutron fluxes to mass of plutonium.

The gamma-emitting nuclides were readily identified by standard gamma-assay techniques because in most instances the nuclides are not heavily shielded in the ducts and pipes. In most situations, the amount of shielding is well known and the radioactive material localized. A well collimated intrinsic germanium detector was used to quantify gamma-emitters. Where space permits, measurements are made at more than one orientation and the results averaged to give an accurate estimate of the contents inside ducts and pipes. 


\subsection{Measurements}

The measurements were conducted according to the following documents:

- Pacific Northwest Laboratory Quality Assurance Plan QAP FO-1, QA Plan for Safeguards Nondestructive Assay Measurements

- Pacific Northwest Laboratory Nondestructive Assay Measurement Procedure MCA-510, Holdup Assay Measurements (see Appendix A).

\subsection{Measurement and Test Equipment}

The neutron and gamma assay systems are "user to calibrate" equipment. The individual components are configured and tested as a system, and then the entire system is calibrated with appropriate calibration/verification standards. The neutron and gamma assay systems are calibrated with check sources and calibrations standards traceable to the NIST.

\subsection{Calibration Standards}

Calibration standards are used in a measurement system to establish the relationship between the basic instrument response and the attributes of interest. The quality of the calibration is ensured by selecting the appropriate standard. The standard must be a physically and chemically stable item for which the attributes of interest are well characterized and for which other properties affecting the measurement are known. In this case, the count rate from neutrons, the amount of shielding, and the orientation and distance from the detector to the neutron source are related to the mass of weapons-grade plutonium. The mass of other forms of plutonium can be inferred from the calculated neutron emission rates. The calibration of the gamma assay equipment is more straightforward. The counting efficiency of the gamma spectrometer with a collimator can be measured using calibration sources of known activity and photon emission rates. The viewing angle and efficiency can be determined directly from measurements, as shown in Figure 1.2.

Records indicate that the material in the hot cells and laboratories was from a wide variety of sources, including both low-exposure and high-exposure reactor fuel samples. For these measurements, it was - assumed that the plutonium would be low-exposure plutonium oxide with relatively low neutron emission rates (typically 150 neutrons/second/gram of plutonium). To give conservative results, any high neutron yields from alpha-neutron reactions were ignored. The neutron energy spectrum from plutonium dioxide is shown in Figure 3.1, taken from the document Neutron Spectra of Plutonium Compounds, BNW-1262 (Brackenbush and Faust 1970). 


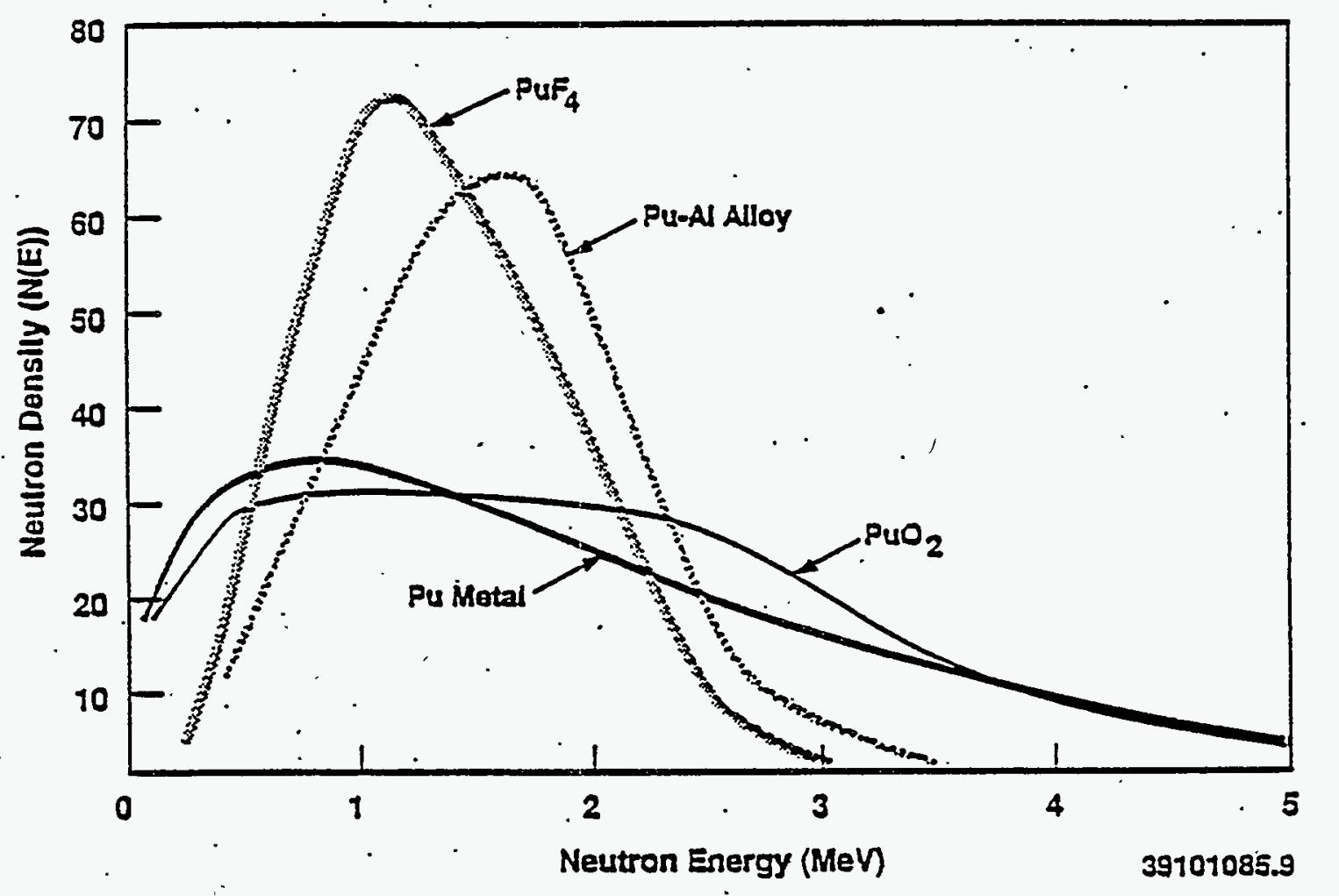

Figure 3.1. Neutron Energy Spectra from Plutonium Compounds

Two neutron sources were selected for use in calibrating/verifying the neutron detector assay system. The first was a small $0.3-\mu \mathrm{g}^{252} \mathrm{Cf}$ neutron calibration source. This source's neutron dose rates have been determined by comparison with other neutron sources whose calibrations are directly traceable to NIST. This source has a neutron energy spectrum very similar to that of plutonium dioxide. (See ${ }^{252} \mathrm{Cf}$ Shielding Guide, DP-1246 [Stoddard and Hootman 1971] or NBS Special Publication 633 [Schwartz and Eisenhauer 1982].) This source was used to determine the angular efficiency of the slab detector in the laboratory prior to the holdup measurements at the 325 Building.

A sample of weapons-grade plutonium oxide was selected as the reference material standard for determining the basic instrument response for the attributes of interest. Specifically, the mass of plutonium in the reference material was related to the neutron count rate in the neutron detector. Weapons grade plutonium has a lower neutron emission rate than the higher exposure reactor-grade plutonium samples and should yield conservative (i.e., higher) plutonium mass estimates. The plutonium oxide sample (LLNL ash sample RA 146A) selected for the reference standard contains 108 grams of plutonium with the isotopic composition given in Table 3.1. The reference standard has been measured by several nondestructive assay (NDA) systems used for measuring safeguard mass confirmatory standards. Data for this sample from high-level neutron coincidence counting and calorimetry with isotopic compositions obtained from gamma spectroscopy are in good agreement with the.book values assigned by LLNL when the material was shipped to PNNL. 
Table 3.1. Isotopic Composition of Plutonium Ash Reference Material, Weight Percent Isotope

\begin{tabular}{lccccccc} 
& $\frac{{ }^{238} \mathrm{Pu}}{\text { Weight }}$ & 0.13825 & $\frac{{ }^{239} \mathrm{Pu}}{93.452}$ & $\frac{{ }^{240} \mathrm{Pu}}{6.101}$ & $\frac{{ }^{241} \mathrm{Pu}}{0.2793}$ & $\frac{{ }^{242} \mathrm{Pu}}{0.019}$ & $\frac{{ }^{241} \mathrm{Am}}{0.220}$ \\
Percent & & & & & & & \\
Isotope & $\pm 1.53 \%$ & $\pm 0.15 \%$ & $\pm 2.21 \%$ & $\pm 1.22 \%$ & $\mathrm{n} / \mathrm{a}$ & $\pm 1.4 \%$ \\
\hline
\end{tabular}

Note: Calculated age from ratio of ${ }^{241} \mathrm{Am} /{ }^{41} \mathrm{Pu}$ is. $12.3 \pm 0.33$ years.

\subsection{Measurement and Quality Control}

The measurement personnel had the complete responsibility for monitoring and evaluating the quality of the data. Any indication that the system was out of calibration (e.g., significant gain shifts in the position of the thermal neutron peak or high gamma levels that produce pile-up in the neutron events) required the stoppage of work until the problem was resolyed. Before NDA measurements were initiated, the overall system was calibrated. To verify the proper operation of the neutron assay system, the entire system was assembled in the laboratory and components checked for proper operation. Then, verification measurements were performed using a known mass of plutonium before and after the measurements in the 325 Building. 'All of the spectral data collected during the measurements were recorded on computer files and can be retrieved if questions should arise.

A measurement control check was performed daily before the equipment was used, and the results recorded. For the neutron assay system, the detector was positioned at a fixed location 12 in. from an AmBe reference source stored in Room 42 in the basement. The measurement control check was used to check the position of the thermal neutron peak and verify that the integral of the neutron events for a 300-second count remained constant throughout the duration of the measurements. For the gamma assay system, the germanium detector was exposed to a calibration source containing a known activity of radioactive material. An analysis of photopeak areas and channel number is used to verify that the gain and sensitivity has remained constant. These procedures are recorded in Appendix A, and the data are archived on magnetic storage media.

\subsubsection{Preparations for Measurement and Test Equipment}

The approach to the problem of NDA assay was to select a very sensitive neutron detector to measure the neutrons emitted by any TRU (plutonium) contained in the ducts, filter boxes, and pipes. The detector requirements included sufficient sensitivity to measure sub-gram quantities of plutonium at accessible measurement locations. A slab neutron detector was selected for the measurements because of its sensitivity and directionality. 


\subsubsection{Neutron Slab Detector System}

The neutron detector system consists of

- a neutron slab detector containing several ${ }^{3} \mathrm{He}$ proportional counters inside a polyethylene moderator

- ancillary NIMbin electronics (preamplifier, shaping amplifier, high voltage power supply)

- a multichannel analyzer (MCA) to display and record the neutron spectra from the detector.

The neutron slab detector consists of an array of five cylindrical ${ }^{3} \mathrm{He}$ proportional counters, 1 in. in diameter by approximately $22 \mathrm{in}$. long, which are filled with four atmospheres of ${ }^{3} \mathrm{He}$ to detect slow neutrons. The proportional counters are inside a slab of polyethylene moderator at a depth of $2 \mathrm{in}$. from the front face and 4 in. from the back face. The tubes are carefully selected to have the same gain and are connected in parallel to a preamplifier and high voltage supply. The nominal operating voltage is +1400 volts. The polyethylene slab is $6 \mathrm{in}$. deep, $16 \mathrm{in}$. wide, and $24 \mathrm{in.} \mathrm{long.} \mathrm{The} \mathrm{detector} \mathrm{is} \mathrm{a} \mathrm{standard} \mathrm{design} \mathrm{used} \mathrm{for}$ NDA safeguards assay and is described in Section 14.4.2 of NUREG/CR-5550, Passive Nondestructive Assay of Nuclear Materials (Reilly et al. 1991).

The NIMbin electronics include a high-voltage power supply to provide a regulated voltage of +1400 volts $\mathrm{DC}$ to operate the proportional counters and a shaping amplifier to convert the signals from the preamplifier to pulses that can be processed by the MCA. An MCA was used to display the spectra, so that any possible gamma interference or instrument malfunction could be detected immediately. Data from the MCA (Canberra Series 35 Plus) were recorded on a laptop computer with a hard disk for permanent data storage. Data from the computer was also backed up on floppy disks as a.precaution. If there is any question about a measurement, the spectral data can be retrieved and examined later.

\subsubsection{Gamma Assay System}

A $20 \%$ efficient HPGe detector was used to determine radionuclide identification and quantities present at various measurement locations. The gamma assay system is composed of the latest innovative hardware and software commercially available.

\subsection{Pretest Verifications}

- Pretest verifications consisted of testing the electronic equipment, making angular response measurements, and calibrating the slab detector with plutonium oxide.

\subsubsection{Testing of Electronics}

The neutron slab detector and supporting electronics were assembled in the laboratory, and all of the electronic components were checked to assure proper operation in the field. The electronics were placed in the NIMbin and the cables connected for the signals, high voltage, and preamplifier power. The methods 
in the NIMbin and the cables connected for the signals, high voltage, and preamplifier power. The methods used to verify the proper operation of the equipment in the laboratory generally followed the methodology given in Neutron Dosimetry at Commercial Nuclear Plants, NUREG/CR-3610 (Brackenbush et al. 1984), which describes the setup of neutron spectrometry equipment using ${ }^{3} \mathrm{He}$ proportional counters. The output signals from the shaping amplifier was examined by exposing the detector to $\mathrm{a}^{252} \mathrm{Cf}$ neutron source in the laboratory and observing the pulses with an oscilloscope to examine the pulse shape. Adjustments are made to correct for amplifier gain and pole zero to minimize pulse overshoot or undershoot, so that the pulse returns to the baseline in the shortest possible time to reduce pulse pile-up and allow operation in high count rates. Because this adjustment depends on the cable capacitance, the entire system was tested, including the long cables that were to be used. If any component failed, there were backup units that were also checked.

The equipment was calibrated as a complete system before the 325 Building measurements were initiated. Following safeguards measurement procedures, the system was calibrated at the system level. It is not necessary, or even desirable, to calibrate the individual components of the system, because proper operation of the system and accurate interpretation of the results cannot be obtained from individual component electronic calibration. System malfunctions usually can be easily identified from the spectra recorded during the measurements. Proper operation of the system was verified with measurements using a known mass of plutonium.

The calibration/verification measurements consisted of measuring the angular response and response to room-scattered neutrons using the $0.3-\mu \mathrm{g}{ }^{252} \mathrm{Cf}$ neutron source in the ESB Building at PNNL. The response of the detector would then be known at any angle and distance to a fission source. The mass of the plutonium was then correlated to the neutron count rate from the slab detector by exposing the detector to the $108 \mathrm{-g}$ plutonium oxide source in the 324 Building.

Figure 3.2 shows a typical spectrum obtained from the ${ }^{3} \mathrm{He}$ proportional counters in the slab detector exposed to a neutron source. In this graph, the ordinate is the logarithm of the number of counts from the detector, and the abscissa is the energy deposited in the detector by gamma rays and neutrons.

There is a clear separation between gamma events, shown on the left side of the plot, and neutron events. Gamma events can be eliminated by setting a region of interest and integrating only neutron events, as shown in Figure 3.2.

However, pulse pileup can occur in intense gamma fields, when several gamma pulses are counted within the resolving time of the electronics. This produces a gamma continuum that can extend into the neutron event region. The slab detector was exposed to a ${ }^{137} \mathrm{Cs}$ gamma source in the ESB laboratory to determine the operating range in high radiation fields. There is no significant gamma pile-up that could interfere with the neutron detector at gamma exposure rates up to $1 \mathrm{R} / \mathrm{h}$. The detector can function in gamma fields as high as $35 \mathrm{R} / \mathrm{h}$, but there is serious gamma pile-up, and the region of interest must be adjusted. The spectral data were recorded, so that all of the measurements can be reviewed later, if necessary. 


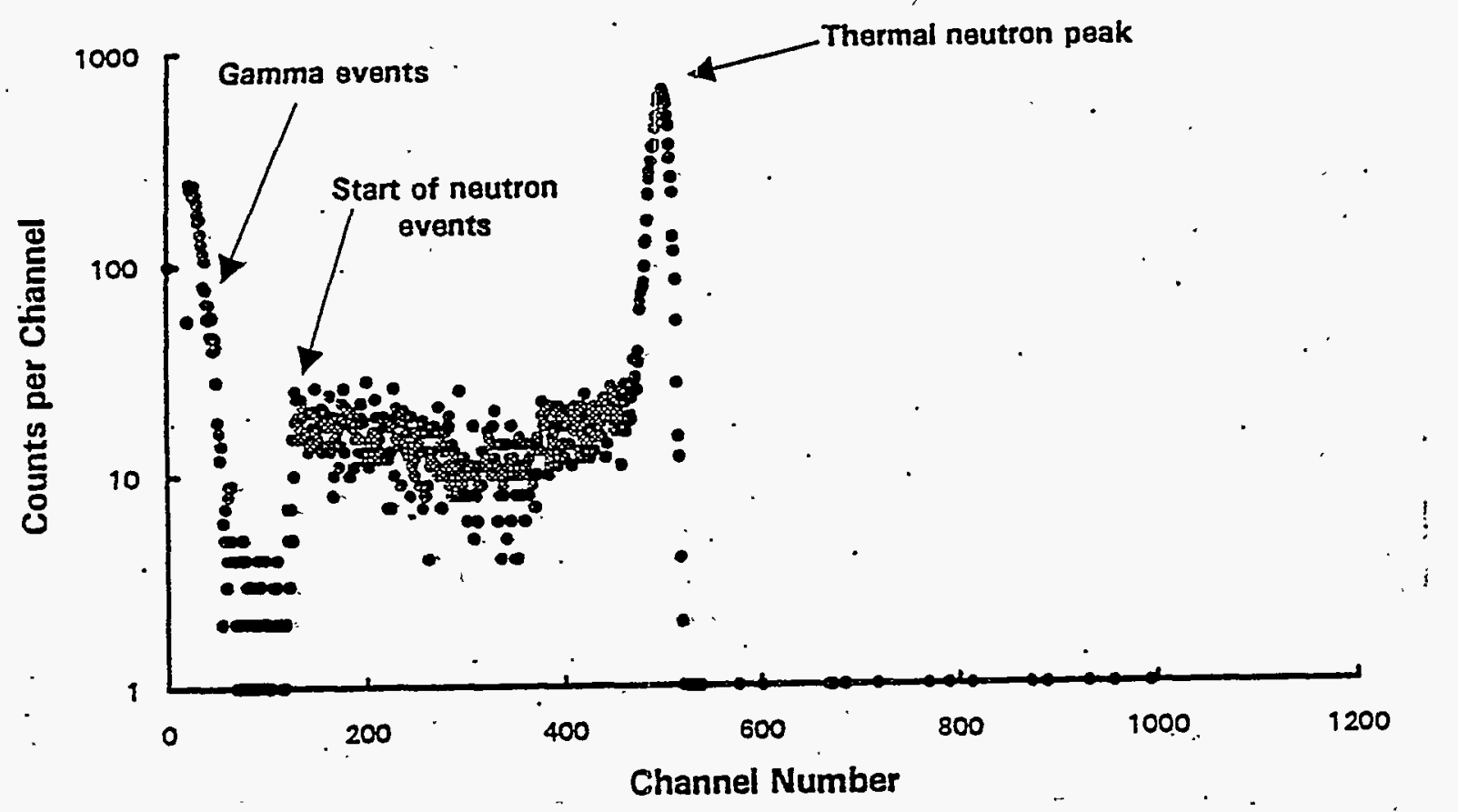

Figure 3.2. Energy Deposition Spectrum from the ${ }^{3} \mathrm{He}$ Proportional Counters Exposed to a Neutron Source

\subsubsection{Angular Response Measurements}

The first set of calibration/verification measurements were made in the ESB Building laboratory, using the $0.3-\mu \mathrm{g}{ }^{252} \mathrm{Cf}$ neutron source to set up the system electronics and determine the angular response of the slab detector. The response of the detector as a function of polar and azimuthal angles is given in Figures 3.3 and 3.4, respectively. Angles are measured in reference to an axis normal to the center of the front face of the slab detector. (The front face has the five ${ }^{3} \mathrm{He}$ tubes located at $2 \mathrm{in}$. below the surface of the plastic moderator.) The azimuthal angles are measured in the plane passing through the longest axis of the rectangular slab; polar angles are measured in a plane at right angles to the longest axis of the rectangular slab. These measurements were made in the ESB Building laboratory at a height of $4 \mathrm{ft}$ above the floor. The angular responses were measured with the slab detector positioned vertically on a turntable; the neutron source was at a distance of $6 \mathrm{ft}(2 \mathrm{~m})$ from the center of the ${ }^{3} \mathrm{He}$ tubes. The graphs demonstrate that the angular counting efficiency does not change dramatically if the source is slightly off-axis, and that neutrons entering the back side of the detector are counted at about $50 \%$ of the efficiency of those entering the front.

\subsubsection{Calibration of Slab Detector with Plutonium Oxide}

The slab detector was also calibrated in the 324 Building by exposing the detector to a 108-g sample of plutonium oxide.(LLNL sample RA 146A) at a height of $4 \mathrm{ft}$ above the floor and in a vertical configuration. The 108-g plutonium source has been described previously in Section 2.0. As will be 


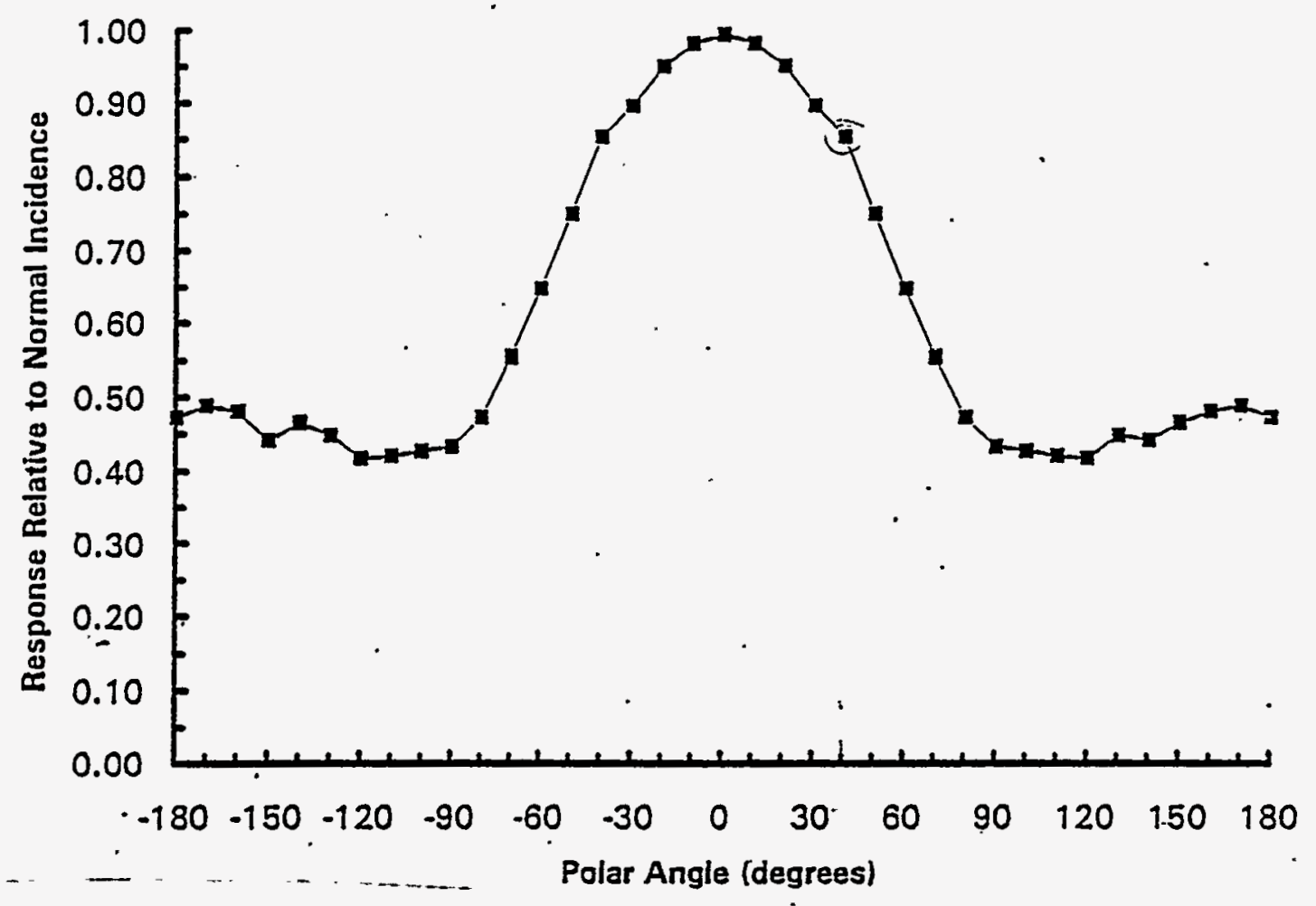

Figure 3.3. Relative Angular Response of the Slab Neutron Detector as a Function of Polar Angle

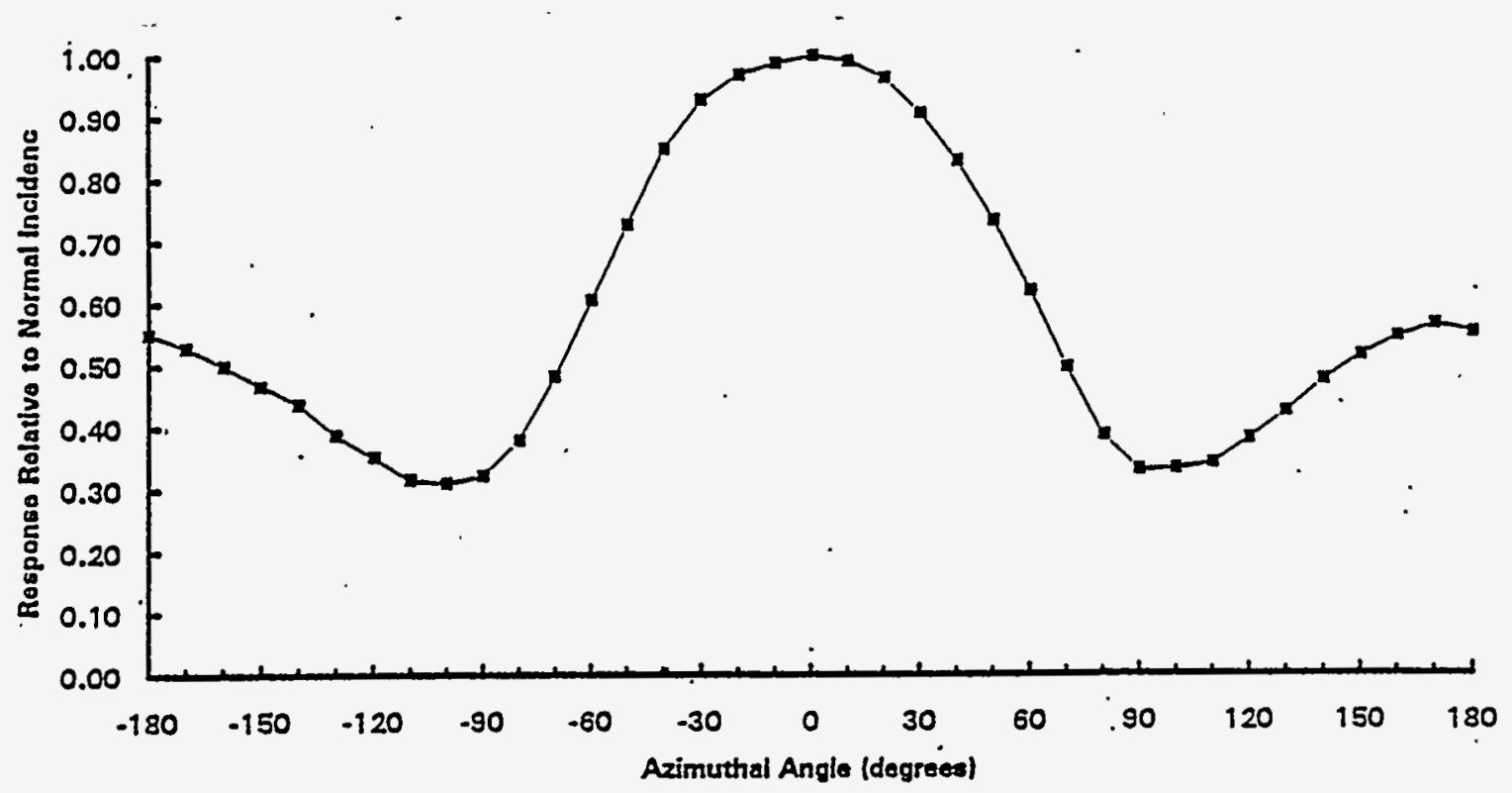

Figure 3.4. Relative Angular Response of the Slab Neutron Detector as a Function of Azimuthal Angle 
explained in Section 4.0 on data analysis, it is possible to correct for the effects of room-scattered neutrons from the series of measurements that relate distance to the measured neutron count rate. After these measurements were completed, it was possible to relate the mass of weapons-grade plutonium to the measured count rate, the distance from the detector, and the angle of incidence. As will be explained in the data analysis in Section 4.0, it is even possible to correct for the effects of neutrons scattered within the facility from inverse square measurements performed in the 324 Building.

Measurements were also made in the 324 Building using various thicknesses of steel and aluminum to estimate the effects of shielding. The shields were approximately 2 -ft square and were positioned near the plutonium source to effectively shield it from the slab detector. The can of plutonium oxide containing the $108 \mathrm{~g}$ of plutonium was positioned on its side on the floor inside a "cave" of steel and lead bricks.

Measurements were then made with the bare source and with the source covered with large slabs of iron and aluminum positioned on top of the can containing the plutonium oxide. The steel and lead cave prevented neutrons from scattering around the edges of the intervening shield materials. Results of the shielding measurements are given in Table 3.2. Note that the neutrons were not absorbed like gamma rays in steel shields; the neutrons scattered within the shield and were lower in energy. These data indicate that even 2 in. of steel or aluminum does not greatly influence the measured neutron flux.

Table 3.2. Effect of Steel and Aluminum Shielding Materials Placed Between the Plutonium and the Slab Neutron Detector

\begin{tabular}{|c|c|c|}
\hline Shield Material & $\begin{array}{c}\text { Thickness } \\
\text { (in.) }\end{array}$ & $\begin{array}{c}\text { Attenuation } \\
\text { Factor } \\
\end{array}$ \\
\hline \multirow[t]{6}{*}{ Steel } & None & 1.00 \\
\hline & 1 & 0.85 \\
\hline & 2 & 0.75 \\
\hline & 3 & 0.68 \\
\hline & 4 & 0.6 \\
\hline & 6 & 0.49 \\
\hline \multirow[t]{6}{*}{ Aluminum } & None & 1 \\
\hline & 0.5 & $0.94^{\circ}$ \\
\hline & 1.5 & 0.84 \\
\hline & 2 & 0.8 \\
\hline & 3.5 & 0.68 \\
\hline & 4 & 0.65 \\
\hline
\end{tabular}




\subsection{Neutron Measurements in the 325 Building}

Operational and background checks were made for neutron levels.

\subsubsection{Operational Check}

After the preliminary measurements were completed in the laboratory and the system was functioning properly, the holdup measurements commenced in the 325 Building basement in Room 45 . Here, the neutron detector was connected to the MCA via 100-foot-long cables, so that the operator could remain in one area while the detector was positioned near the various ducts and piping. Before the measurements were started, an AmBe reference source stored in Room 42 was used as an operational source check of the system. The neutron slab detector was positioned $12 \mathrm{in}$. from the source to the front face of the detector. The neutron event spectrum, similar to that shoiwn in Figure 3.2, was measured and recorded every day to verify that the detector and ancillary electronics were functioning properly. After the operational check indicated that the system was still functioning properly, it was ready for neutron measurements on the ducts and pipes.

\subsubsection{Background Measurements}

Background measurements were performed with the HPGe detector and the neutron counter.

\section{High-Purity Germanium Detector}

Background measurements were taken with the HPGe at various measurement locations. A solid plug replaced the collimator and a background measurement was taken for the same counting time as the collimated measurement. The background contribution was subtracted from the collimated measurement with analysis conducted on the resulting background-corrected spectrum.

A small, low-power neon laser was used to align the gamma detector to the desired measurement location on the duct, RLWS line, or other measurement location of interest. Detector-to-source distance was measured using a SONIN sonic measuring unit. Accuracy of the distance measurement was. $\pm 0.5 \mathrm{~cm}$.

\section{Neutron Measurement System}

Other neutron sources in the building could contribute significantly to the neutron count rate, so careful background measurements were made before any measurements were made on the ducts or pipes. If the neutron count rates were too high, it would be necessary to modify the measurement plan.

The detector was designed to have a directional response, so that fission neutrons entering from the back side would be counted with only half the efficiency of those entering from the front of the slab detector. Background measurements were made on the periphery of the area around the ducts and filter boxes. The slab detector was positioned in a vertical orientation to measure the general background. At 
a given position, a measurement was taken; then, the slab detector was rotated $180^{\circ}$ and the meașurement repeated. This procedure gave pairs of neutron count rates with the detector facing the source and pointed away from the suspected neutron source. These data allowed the average room background at each location to be determined, as explained in Section 4.0 on data analysis. 


\subsection{Analysis of Data}

Data was analyzed for both the calibration/verification measurements and for measurements taken in the 325 Building.

\subsection{Analysis of Calibration and Verification Measurements}

The calibration or verification measurements made before the 325 Building holdup measurements allow one to correlate the mass of weapons-grade plutonium to the measured neutron count rate and account for scatter of neutrons from the walls, floor, and ceiling of the room. This method of correcting for scatter from inverse square measurements is presented in the NBS Special Publication No. 633 (Schwartz and Eisenhauer 1982). The response of any moderated neutron detector can be modeled as a response to neutrons coming directly from the source and a response to neutrons scattered from the floor, walls, and ceiling of the room. If the detector is more than $1 \mathrm{~m}$ from the floor and walls, the scattered component can be assumed to be a constant. This can be expressed mathematically by Equation 4.1 :

$$
C=\frac{M}{r^{2}} B
$$

where $C=$ the count rate (cts/s)

$M=$ the mass of plutonium in grams (directly proportional to the neutron source strength)

$\mathrm{B}=$ the neutron background in the room due to scatter from the floor, walls, and ceiling

$r=$ the distance (in feet) from the plutonium source to the centerline of the proportional counters.

Multiplying by $\mathrm{r}^{2}$ gives Equation 4.2:

$$
\mathrm{Cr}^{2}=\mathrm{MBr}^{2}
$$

In the limit that $\mathrm{r}^{2}$ approaches zero, the term $\mathrm{Br}^{2}$ approaches zero while the term $\mathrm{Cr}^{2}$ approaches a constant. Plotting the product of the count rate times the distance squared versus the distance squared produces a straight line if the detector is not too close to the source or walls. An example of the inverse square plot from the 108-g plutonium oxide source is shown in Figure 4.1. A straight line has been fitted to the data points. The intercept on the ordinate axis is proportional to the neutron source strength or mass of plutonium, and the difference between the intercept and the value on the straight line gives the contribution to room scatter. In some small rooms, the scatter can be as high às $50 \%$ of the count rate at distances of $6 \mathrm{ft}(2 \mathrm{~m})$ from the neutron source. Thus, it is important to correct for the effects of room scatter. 


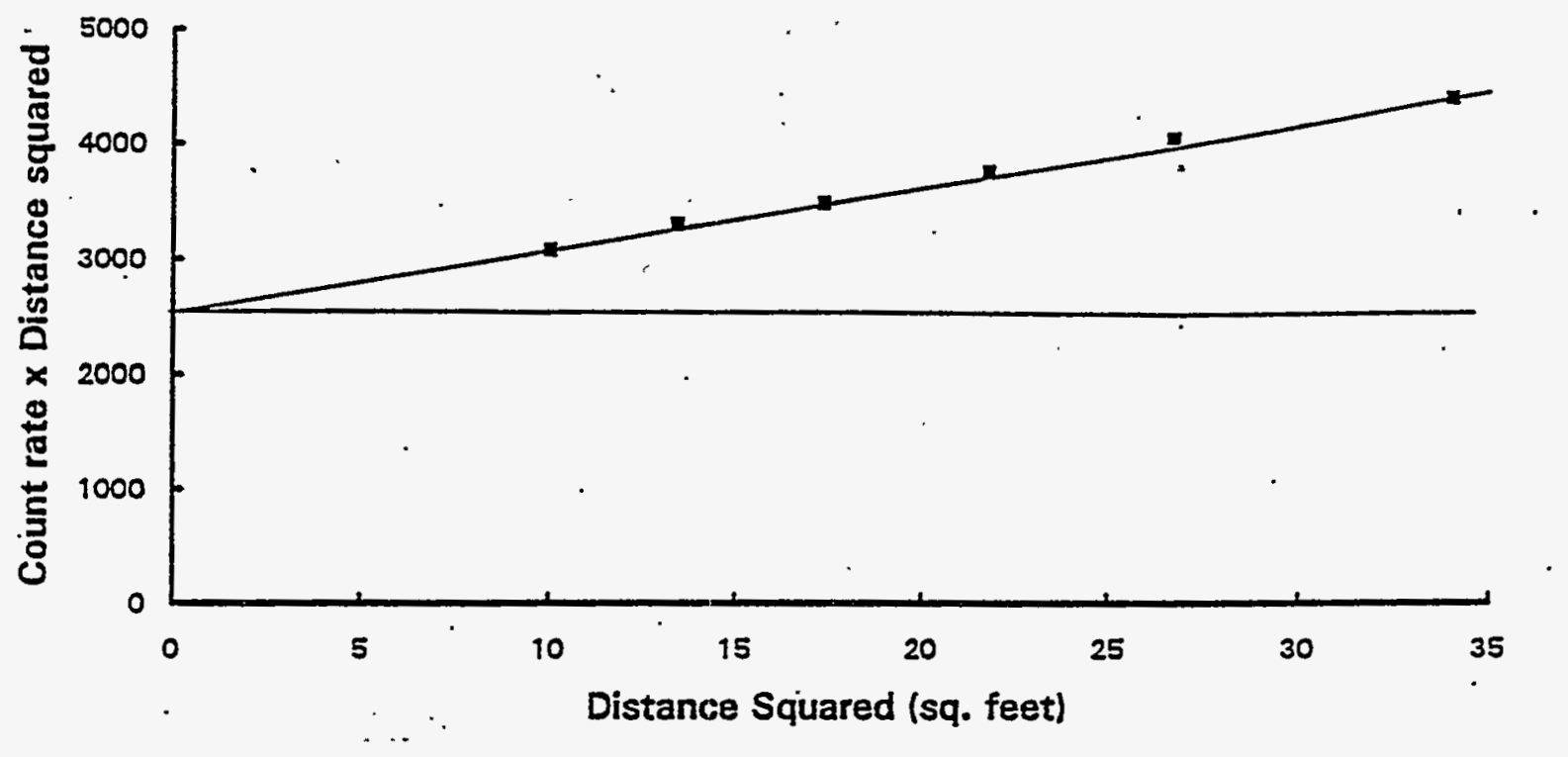

Figure 4.1. Example of Inverse Square Measurements with Neutron Slab

Detector Exposed to a Plutonium. Oxide Source Containing 108 Grams of Plutonium

This technique can be used to correlate the detector count rate to the mass of plutonium. Consider the case where the can of plutonium oxide was $4 \mathrm{ft}(1 \mathrm{~m})$ above the floor and the slab neutron detector was positioned vertically. The least squares fit gives the values for the slope and $y$-intercept of a straight line fitted to the inverse square data points in Figure 4.1. Dividing the slope and intercept values by the mass of plutonium $(108 \mathrm{~g}$ ) gives the results normalized to $1 \mathrm{~g}$. The normalized $\mathrm{y}$-intercept is 0.507 , and the normalized slope is 23.66. Putting these values into Equation 4.1 gives an expression for the count rate per gram of plutonium for the slab detector, oriented vertically at $4 \mathrm{ft}$ above the floor. This is expressed mathematically by Equation 4.3:

$$
\mathrm{cts} / \mathrm{s} / \mathrm{g}=0.507+\frac{23.7}{\mathrm{r}^{2}}
$$

where $\mathrm{r}$ is the horizontal distance in feet between the plutonium source and the centerline of the ${ }^{3} \mathrm{He}$ proportional counters at $4 \mathrm{ft}$ above the floor.

\subsection{Analysis of 325 Building Measurements}

The estimate of the amount of plutonium holdup in the 325 Building depends on the assumptions made concerning the following factors:

- the composition, age, and location or distribution of the plutonium 
- the position of shielding materials around the plutonium sources

- the neutron background in the area around the plutonium sources.

\subsubsection{Basic Assumptions Used for Calculations}

It is possible that there is very little plutonium in the ducts and piping. Many of the measured neutrons could originate from alpha-neutron reactions in low-atomic-number materials, such as borosilicate glass in HEPA filters, and from the many sealed sources and samples stored in the basement and first-floor laboratories. It is more probable that the neutrons originate from plutonium and other transuranics (such as ${ }^{241} \mathrm{Am}$ ) in the ducts and piping, and great care must be taken in distinguishing between room background and plutonium source neutrons. For all the calculations, the following assumptions were used:

- The neutron emissions were from plutonium and its decay product, ${ }^{241} \mathrm{Am}$, in the form of an oxide, which is the most stable chemical form. Nitrates, oxylates, hydrated oxides, and hydroxides would produce similar neutron yields. Neutrons from other transuranics were ignored. This results in conservative estimates for the mass of plutonium.

- There is little interference from other plutonium compounds, such as fluorides, or from alpha-neutron reactions with low-atomic-number elements, such as beryllium, boron, aluminum, or sodium. It is difficult to judge whether there is a significant contribution from alpha-neutron reactions without more sophisticated measuring equipment that can measure two neutrons in coincidence from a single fission event. (Alpha-neutron events would produce only random coincidences.)

- Each plutonium sọurce is treated separately and does not interact with other plutonium sources (i.e., there is no multiplication).

- Any multiplication effects were ignored, which is a good assumption for gram quantities of plutonium. There may have been some increase in the neutron emissions from the $108 \mathrm{~g}$ plutonium sample used as the verification standard, but any errors introduced will be small in comparison with other sources of error or uncertainty.

- Any plutonium holdup is low-exposure plutonium with very little ${ }^{240} \mathrm{Pu}$. The weapons-grade plutonium from LLNL (ash sample RA 146A) is assumed to be representative of the plutonium in the. holdup material. This is a reasonable assumption and will produce conservative estimates. Any plutonium present with a higher ${ }^{240} \mathrm{Pu}$ content will emit more neutrons per gram; consequently, the mass of plutonium will be overestimated.

\subsubsection{Neutron Background}

Before the measurements on the ducts and pipes were initiated, some measurements were made to determine the neutron backgrounds of the periphery of the area. When a source was located, two measurements were made: one measurement with the front face of the detector pointing towards the suspected plutonium source, and a second méasurement with the slab detector pointing away from the source. 
Measurements were made with the slab neutron detector oriented at.right angles to the suspected source, i.e., the long axis of the slab was perpendicular to the source. In general, the effective "field of view" was about 3 to $4 \mathrm{ft}$ at a distance of 1 to $2 \mathrm{ft}$ from the suspected plutonium source. The following discussion demonstrates how it is possible to estimate the effects of room background with the slab detector oriented at right angles to a suspected plutonium source in the ducts or piping.

Consider the example of a bottom prefilter box on the west side of the SERF cell in the 327 Building basement. The slab neutron detector was positioned directly to the side of the prefilter box at a distance of 12 in. from the surface of the iron shield placed around the box. With the front face of the slab detector pointed towards the prefilter box, the measured neutron count rate was $8.84 \pm 0.27 \mathrm{cts} / \mathrm{s}$. When the detector was rotated $180^{\circ}$ so that the front of the detector was pointed away from the filter, the measured count rate was $4.48 \pm 0.19 \mathrm{cts} / \mathrm{s}$. We can be reasonably certain that there were no neutron sources directly in front of the slab detector when it was pointed away from the filter box.

Fission neutrons entering from the back of the detector were counted with about $53 \%$ of the efficiency of neutrons entering from the front face, as shown by the experimental data for angular efficiency discussed in Section 3.4.3. Let $x$ represent the counts from the source and $y$ represent the counts from . room background. The count rate measured with the vertical slab detector pointed toward the suspected source is the sum of the counts from neutrons entering the front and $50 \%$ of the neutrons entering from the back:

$$
\mathrm{x}+0.50 \mathrm{y}=8.84 \mathrm{cts} / \mathrm{s}
$$

Likewise, the count rate measured with the vertical detector pointing away from the prefilter box and facing the room is the sum of the neutrons entering from the front (or room background neutrons) and 50\% of the neutrons entering from the back side:

$$
\mathrm{y}+0.50 \mathrm{x}=4.48 \mathrm{cts} / \mathrm{s}
$$

Solving the two simultaneous equations for $x$ and $y$ gives:

$y=0.08 \mathrm{cts} / \mathrm{s}$ for neutrons from room background

$\mathrm{x}=8.80 \mathrm{cts} / \mathrm{s}$ for neutrons emanating from the filter box.

Thus, we must correct the measured count rates by subtracting away $0.08 \mathrm{cts} / \mathrm{s}$ due to the neutron background in the room. This is a selected example in which the plutonium in the filter box is well isolated and the count rates are much higher than the general room background. In every other measured location, the count rate with the slab detector pointed towards the suspected plutonium source is similar to the count rate with the detector pointed away from the source. The background-corrected count rates are given in the data table in the spreadsheet calculations in Appendix C. 


\subsubsection{Calculated Mass of Plutonium}

Once the contribution from room background is calculated (or estimated from measurement in the general area), it is possible to use Equation 4.3 to estimate the effects of room scatter and determine the mass of weapons-grade plutonium $\left(6 \%{ }^{240} \mathrm{Pu}\right)$ in the source, if the distance to the center of the plutonium source is known. In the case of the prefilter box, discussed in the previous section, the dimensions of the box were $31.5 \mathrm{in}$. long by $31 \mathrm{in}$. high: the box was shielded by $2.5 \mathrm{in}$. of iron. The center of the slab neutron detector was $12 \mathrm{in}$. from the surface of the iron shield covering the filter box. If we assume that the plutonium is uniformly spread over the filter, the plutonium source can be modeled as a point source at a distance of $31.5 / 2+2.5+12=30.25 \mathrm{in}$. $(2.52 \mathrm{ft})$ from the center of the detector. Substituting a distance of $2.52 \mathrm{ft}$ into Equation 4.3 gives:

$$
0.507+\frac{23.7}{(2.52)^{2}}=4.24 \mathrm{cts} / \mathrm{s} / \mathrm{g}
$$

Dividing the measured count rate of $8.80 \mathrm{cts} / \mathrm{s}$ by $4.24 \mathrm{cts} / \mathrm{s} / \mathrm{g}$ of plutonium gives a value of $2.1 \mathrm{~g}$ of plutonium in the filter box. It may be somewhat suspect because alpha-neutron reactions from finely divided alpha-emitters on borosilicate glass fiber can produce elevated neutron levels. Because the neutron emission rates from higher-exposure plutonium are higher than for weapons-grade plutonium, the value of $2.1 \mathrm{~g}$ of plutonium is an upper limit on the amount of plutonium that may be in the prefilter box. 


\subsection{Results}

The results of this survey indicate that no significant levels of plutonium reside in the exposed ductwork or piping in the basement of the 325 Building. There are, however, significant quantities of plutonium remaining in the laboratory fume hoods and gloveboxes. Section 5.1 presents neutron measurement results; Section 5.2 similarly summarizes the gamma measurement results. Appendix C contains the complete set of data and analyses for the neutron measurements.

\subsection{Neutron Measurement Results}

Neutron measurements of the 325 Building ductwork, laboratory vacuum system lines and RLWS pipes were taken at suspected source locations using the neutron slab detector. Neutron measurements - were also taken on each fume hood and glovebox where fissile material had been processed. Two sets of plutonium mass estimates were determined using an assumed weapons-grade isotopic composition for the maximum plutonium mass and a reactor fuel isotopic composition $\left(11 \%{ }^{240} \mathrm{Pu}\right)$ for the most likely mass. An exception is the Laboratory Vacuum System (LVS) where the most likely mass of plutonium is based on $16 \%{ }^{241} \mathrm{Am}, 83.5 \%{ }^{239} \mathrm{Pu}$, and $0.5 \%{ }^{238} \mathrm{Pu}$ from radiochemistry results of the LVS slab tank samples. Table 5.1 details the results of the neutron measurements for the exposed HEPA filters, ducts, RLWS lines, and LVS lines in the basement of the 325 Building. Table 5.2 lists the neutron measurement results for the RLWS lines in the basement. Results for each fume hood and glove box measured are listed by room number in Table 5.3 and include any source material present at the time of the measurements. Special attention was given to "hot spots" with high gamma activity, which were assumed to be spent fuel debris in the pipes or ducts.

Totals for all neutron measurement locations are

$$
\begin{array}{ll}
\text { maximum } & 637 \pm 190 \mathrm{~g} \\
\text { most likely } & 386 \pm 120 \mathrm{~g} .
\end{array}
$$

A summary of plutonium holdup by system and location is presented in Table 5.4. The largest quantities of holdup are found in the glove boxes in the first floor laboratories. However, a significant portion of that, approximately $195 \mathrm{~g}$, is source material in containers identified by fissile material labels.

\subsection{Gamma Measurement Results}

A summary of radionuclide curie content in the RLWS line is presented in Table 5.5. The data identifies the measurement location and estimated activity level at each location. Appendix B contains figures that show the measurement locations. Figure 5.1 shows a plot of the ${ }^{137} \mathrm{Cs}$ content of the RLWS lines. Radionuclide content at other gamma measurement locations is presented in Table 5.6. 
Table 5.1. Plutonium Holdup in Ductwork, LVS, HEPA, RPS, and RLWS Lines in 325 Basement

\begin{tabular}{|c|c|c|c|}
\hline Location & $\begin{array}{c}\text { Maximum } \\
\text { Plutonium }(\mathrm{g})^{(\mathrm{a})} \\
\end{array}$ & $\begin{array}{c}\text { Most Likely } \\
\text { Plutonium (g) } \\
\end{array}$ & Process \\
\hline $30 a-1$ & 0.05 & 0.03 & Duct \\
\hline $31-1$ & 0.15 & 0.08 & Duct \\
\hline $32-1$ & 8.36 & 4.56 & HEPA \\
\hline $32-2$ & 0.60 & 0.33 & HEPA \\
\hline $32-3$ & 0.62 & 0.34 & HEPA \\
\hline $32-4$ & 4.85 & 2.65 & HEPA \\
\hline $32-5$ & 0.63 & 0.34 & RLWS \\
\hline $32-6$ & 0.00 & 0.00 & RLWS \\
\hline $32-7$ & 2.71 & 1.48 & Duct \\
\hline $32-8$ & 6.35 & 3.47 & Duct \\
\hline $33-1$ & 0.03 & 0.02 & RLWS \\
\hline $45-1$ & 0.50 & 0.27 & HEPA \\
\hline $45-2$ & 0.10 & 0.05 & HEPA \\
\hline $45-3$ & 0.27 & 0.15 & HEPA \\
\hline $45-4$ & 0.23 & 0.13 & Duct \\
\hline $45-5$ & 0.22 & 0.12 & Duct \\
\hline $45-6$ & 0.09 & 0.05 & Duct \\
\hline $45-7$ & 0.35 & 0.19 & HEPA \\
\hline $45-8$ & 5.27 & 2.88 & HEPA \\
\hline $45-9$ & 0.10 & 0.10 & LVS \\
\hline . $45-10$ & 0.27 & 0.15 & Duct \\
\hline $45-11$ & 0.00 & 0.00 & HEPA \\
\hline $45-12$ & 0.01 & 0.01 & LVS \\
\hline $45-13$ & 3.17 & 1.73 & RPS \\
\hline $45-14$ & 0.00 & 0.00 & LVS \\
\hline $45-15$ & 0.68 & 0.68 & LVS \\
\hline $45-16$ & 0.32 & 0.32 & LVS \\
\hline $45-17$ & 0.14 & 0.14 & LVS \\
\hline $45-18$ & 0.43 & 0.43 & LVS \\
\hline $45-19$ & 0.05 & 0.05 & LVS \\
\hline $45-20$ & 0.09 & 0.09 & LVS \\
\hline $45-21$ & 0.07 & 0.07 & LVS \\
\hline $45-22$ & 0.08 & 0.08 & LVS \\
\hline $45-23$ & 0.03 & 0.03 & LVS \\
\hline $62-1$ & 0.06 & 0.03 & HEPA \\
\hline $62-2$ & 0.05 & 0.03 & HEPA \\
\hline $62-3$ & 0.11 & 0.06 & Duct \\
\hline Total & 37.04 & 21.14 & \\
\hline
\end{tabular}

(a) Maximum and most likely plutonium mass estimates are based on 6 and 11 weight percent ${ }^{240} \mathrm{Pu}$, respectively. 
Table 5.2. Plutonium Holdup in RLWS Pipeline in 325 Building Basement

\begin{tabular}{|c|c|c|}
\hline Location & Maximum Plutonium (g) & Most Likely Plutonium (g) \\
\hline RLWS-4 & 0.01 & 0.01 \\
\hline RLWS-5 & 0.02 & 0.01 \\
\hline RLWS-6 & 0.01 & 0.01 \\
\hline RLWS-7 & 0.05 & 0.03 \\
\hline RLWS-8 & 0.03 & 0.02 \\
\hline RLWS-9 & 0.02 & 0.01 \\
\hline RLWS-10 & 0.03 & 0.02 \\
\hline RLWS-11 & 0.00 & 0.03 \\
\hline RLWS-12 & 0.01 & 0.01 \\
\hline RLWS-13 & 0.04 & 0.02 \\
\hline RLWS-14 & 0.05 & 0.03 \\
\hline RLWS-15 & 0.08 & 0.04 \\
\hline RLWS-16 & 0.11 & 0.06 \\
\hline RLWS-17 & 0.41 & 0.22 \\
\hline RLWS-23 & 5.31 & 2.90 \\
\hline RLWS-24 & 1.19 & 0.65 \\
\hline RLWS-25 & 3.16 & 1.73 \\
\hline RLWS-26 & 0.34 & 0.19 \\
\hline RLWS-27 & 0.22 & 0.12 \\
\hline RLWS-28 & 0.16 & 0.09 \\
\hline RLWS-31 & 0.26 & 0.14 \\
\hline Total in RLWS Line & 11.51 & 6.28 \\
\hline
\end{tabular}

(a) Maximum and most likely plutonium mass estimates are based on 6 and 11 weight percent ${ }^{240} \mathrm{Pu}$, respectively. 
Table 5.3. Plutonium Holdup in Laboratory Hoods and Glove Boxes

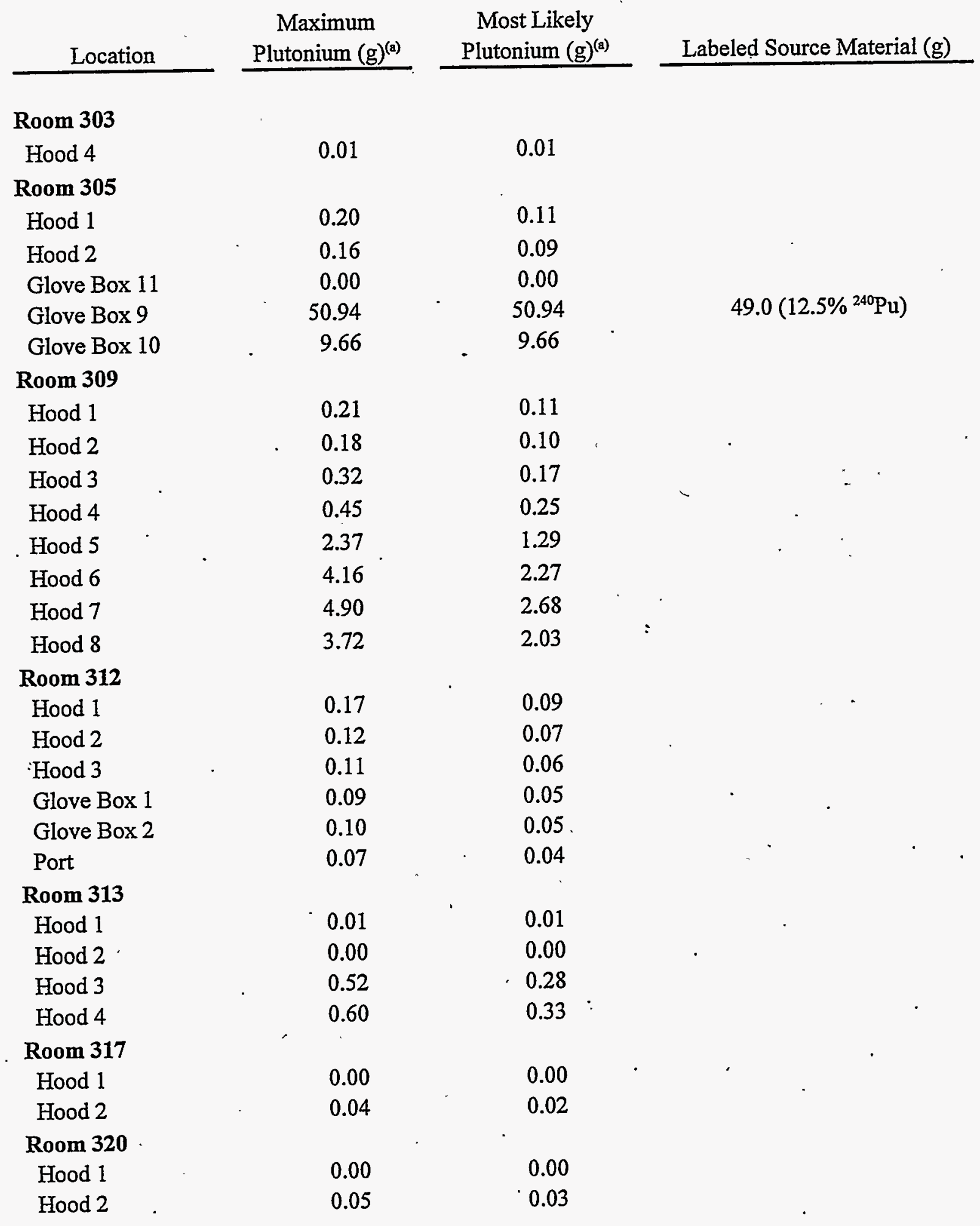


Table 5.3. (contd)

\begin{tabular}{|c|c|c|c|}
\hline Location & $\begin{array}{c}\text { Maximum } \\
\text { Plutonium (g) } \\
\end{array}$ & $\begin{array}{c}\text { Most Likely } \\
\text { Plutonium (g) } \\
\end{array}$ & Labeled Source Material (g) \\
\hline \multicolumn{4}{|l|}{ Room 330} \\
\hline Hood 1 & 0.00 & 0.00 & \\
\hline Hood 2 & 0.00 & 0.00 & \\
\hline Hood 3 & 0.00 & 0.00 & \\
\hline Hood 4 & 0.00 & 0.00 & \\
\hline \multicolumn{4}{|l|}{ Room 401} \\
\hline Hood 1 & 0.04 & 0.02 & \\
\hline Hood 2 & 0.09 & 0.05 & - \\
\hline \multicolumn{4}{|l|}{ Room 406} \\
\hline Hood 1 & 0.75 & 0.41 & \\
\hline Hood 2 & 0.62 & 0.34 & . \\
\hline Hood 4 & 0.76 & 0.42 & \\
\hline Glove Box & 27.60 & 15.07 & \\
\hline \multicolumn{4}{|l|}{ Room 410} \\
\hline Hood 1 & 0.70 & 0.38 & . \\
\hline Hood 2 & 0.57 & 0.31 & \\
\hline Hood 3 & 0.45 & 0.25 & . \\
\hline Hood 4 & 0.76 & 0.42 & \\
\hline Hood 5 & 0.83 & 0.45 & \\
\hline Hood 6 & 2.11 & 1.15 & . \\
\hline \multicolumn{4}{|l|}{ Room 416} \\
\hline Hood 1 & 0.16 & 0.09 & - \\
\hline Hood 2 & 0.14 & 0.08 & \\
\hline Hood 3 & 0.61 & 0.33 & \\
\hline Hood 4 & 0.51 & 0.28 & \\
\hline \multicolumn{4}{|l|}{ Room 419} \\
\hline Hood 1 & 0.05 & 0.03 & \\
\hline Hood 2 & 0.07 & 0.04 & \\
\hline Hood 3 & 0.06 & 0.03 & \\
\hline Hood 4 & 0.00 & 0.00 & \\
\hline Hood 5 & 0.00 & 0.00 & \\
\hline \multicolumn{4}{|l|}{ Room 500} \\
\hline Hood 1 & 6.85 & 3.74 & . \\
\hline Hood 2 & 23.82 & 13.01 & \\
\hline Hood 3 & 0.67 & 0.37 & 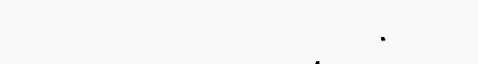 \\
\hline Hood 4 & 0.79 & 0.43 & $\cdot$ \\
\hline
\end{tabular}


Table 5.3. (contd)

\section{Maximum Most Likely}

Location $\quad$ Plutonium $(\mathrm{g})^{(\mathrm{a})} \quad$ Plutonium $(\mathrm{g})^{(\mathrm{a})} \quad$ Labeled Source Material $(\mathrm{g})$

\section{Room 504}

Hood 1

12.19

12.19

11.30

6.17

Glove Box 2

Glove Box 3

21.61

11.8

Glove Box 4

8.57

4.68

\section{Room 506}

Hood 1

Hood 2

10.75

9.89

Hood 3

17.50

Glove Box 31

57.79

9.49

Glove Box 35

Glove Box 37

8.93

Room 507

Hood 1

3.99

Hood 2

2.83

Hood 3

Hood 4

1.62

4.56

Hood 5

22.11

5.87

5.40

9.56

36.20

5.18

4.88

$0.5^{241} \mathrm{Am}, 5.6^{243} \mathrm{Am}$

Room 510

Hood 1

4.50

2.18

Hood 2

Hood 3

Hood 4

4.50

4.37

1.55

0.88

2.49

12.07

13.55

2.46

2.46

2.39

7.40

Room 511

Hood 1

2.39

1.37

1.30

Hood 2

4.33

0.75

Hood 3

3.57

2.36

Hood 4

\section{Room 515}

Glove Box 1

5.35

1.95

Glove Box 2

4.50

2.92

2.46

Room 516

Hood.1

Hood 2

1.66

0.91

1.74

0.95

Hood 4

3.50

1.91

3.59

1.96

5.15

2.81 
Table 5.3. (contd)

Maximum Most Likely

\begin{tabular}{|c|c|c|c|}
\hline Location & Plutonium $(\mathrm{g})^{(\mathrm{a})}$ & Plutonium (g) ${ }^{(\mathrm{a})}$ & Labeled Source Material (g) \\
\hline \multicolumn{4}{|l|}{ Room 517} \\
\hline Hood 1 & 0.82 & 0.45 & \\
\hline Hood 2 & 0.52 & 0.28 & \\
\hline Hood 3 & 0.38 & 0.21 & \\
\hline Hood 4 & 2.08 & 1.14 & \\
\hline Hood 5 & 1.42 & 0.78 & $\therefore$ \\
\hline \multicolumn{4}{|l|}{ Room 528} \\
\hline Hood 4 & 9.17 & 5.01 & \\
\hline Glove Box & 56.26 & 30.72 & \\
\hline \multicolumn{4}{|l|}{ Room 604} \\
\hline Glove Box 36 & 38.63 & 21.09 & $1(5.98 \%), 1(12 \%), 1(19.05 \%)$ \\
\hline Glove Box 38 "A" & 44.49 & 24.29 & $13.0\left(6.61 \%{ }^{240} \mathrm{Pu}\right)$ \\
\hline Glove Box 38 "B" & 19.09 & 10.42 & $32.2\left(6.61 \%{ }^{240} \mathrm{Pu}\right.$ \\
\hline Room 701 & & & \\
\hline Hood 1 & 0.00 & $0.00^{-}$ & \\
\hline Hood 2 & 0.00 & 0.00 & \\
\hline
\end{tabular}

(a) Maximum and most likely plutonium mass estimates are based on 6 and 11 weight percent ${ }^{240} \mathrm{Pu}$, respectively. 
Table 5.4. Summary of Plutonium Holdup in the 325 Building

\begin{tabular}{lcc}
\multicolumn{1}{c}{ Location } & Grams of $\mathrm{Pu}(6 \%)$ & Grams of $\mathrm{Pu}(11 \%)$ \\
\cline { 3 - 3 } RLWS & 12.2 & 6.6 \\
LVS & 2.0 & 2.0 \\
Ducts & 10.2 & 5.6 \\
HEPA & 21.0 & 11.5 \\
RPS & 3.2 & 1.7 \\
Total in Basement & 48.6 & 27.4 \\
Total in Labs & 588.2 & 358.9 \\
Total Holdup + & 636.8 & $\cdots$ \\
Material in Process & & 386.3
\end{tabular}


Table 5.5. Radionuclide Content By Direct Gamma Ray Measurement Using a Collimated High-Purity.Germanium Detector, Curies

\begin{tabular}{|c|c|c|c|c|c|c|}
\hline Location & ${ }^{241} \mathrm{Am}$ & ${ }^{239} \mathrm{Pu}$ & ${ }^{137} \mathrm{Cs}$ & ${ }^{154} \mathrm{Eu}$ & ${ }^{60} \mathrm{Co}$ & ${ }^{152} \mathrm{Eu}$ \\
\hline RLWS 1 & $0.00 \mathrm{E}+00$ & $0.00 \mathrm{E}+00$ & $6.50 \mathrm{E}-06$ & $0.00 \mathrm{E}+00$ & $1.74 \mathrm{E}-07$ & 6.57E-08 \\
\hline RLWS 2 & $0.00 \mathrm{E}+00$ & $0.00 \mathrm{E}+00$ & $6.50 \mathrm{E}-06$ & $0.00 \mathrm{E}+00$ & $1.74 \mathrm{E}-07$ & $6.57 \mathrm{E}-08$ \\
\hline RLWS 3 & $0.00 \mathrm{E}+00$ & $0.00 \mathrm{E}+00$ & $6.50 \mathrm{E}-06$ & $0.00 \mathrm{E}+00$ & $1.74 \mathrm{E}-07$ & $6.57 \mathrm{E}-08$ \\
\hline RLWS 4 & $0.00 \mathrm{E}+00$ & $0.00 \mathrm{E}+00$ & $6.50 \mathrm{E}-06$ & $0.00 \mathrm{E}+00$ & $1.74 \mathrm{E}-07$ & $6.57 \mathrm{E}-08$ \\
\hline RLWS 5 & $0.00 \mathrm{E}+00$ & $0.00 \mathrm{E}+00$ & $4.55 \mathrm{E}-05$ & $0.00 \mathrm{E}+00$ & $1.22 \mathrm{E}-06$ & $4.60 \mathrm{E}-07$ \\
\hline RLWS 6 & $0.00 \mathrm{E}+00$ & $0.00 \mathrm{E}+00$ & $1.95 \mathrm{E}-04$ & $0.00 \mathrm{E}+00$ & $5.22 \mathrm{E}-06$ & $1.97 \mathrm{E}-06$ \\
\hline RLWS 7 & $0.00 \mathrm{E}+00$ & $0.00 \mathrm{E}+00$ & $3.90 \mathrm{E}-05$ & $0.00 \mathrm{E}+00$ & $1.04 \mathrm{E}-06$ & $3.94 \mathrm{E}-07$ \\
\hline RLWS 8 & $0.00 \mathrm{E}+00$ & $0.00 \mathrm{E}+00$ & $4.55 \mathrm{E}-05$ & $0.00 \mathrm{E}+00$ & $1.22 \mathrm{E}-06$ & $4.60 \mathrm{E}-07$ \\
\hline RLWS 9 & $0.00 \mathrm{E}+00$ & $0.00 \mathrm{E}+00$ & $6.50 \mathrm{E}-06$ & $0.00 \mathrm{E}+00$ & $1.74 \mathrm{E}-07$ & $6.57 \mathrm{E}-08$ \\
\hline RLWS 10 & $0.00 \mathrm{E}+00$ & $0.00 \mathrm{E}+00$ & $1.30 \mathrm{E}-04$ & $0.00 \mathrm{E}+00$ & $3.48 \mathrm{E}-06$ & $1.31 \mathrm{E}-06$ \\
\hline RLWS 11 & $0.00 \mathrm{E}+00$ & $0.00 \mathrm{E}+00$ & $1.30 \mathrm{E}-04$ & $0.00 \mathrm{E}+00$ & $3.48 \mathrm{E}-06$ & $1.31 \mathrm{E}-06$ \\
\hline RLWS 12 & $0.00 \mathrm{E}+00$ & $0.00 \mathrm{E}+00$ & $1.30 \mathrm{E}-04$ & $0.00 \mathrm{E}+00$ & $3.48 \mathrm{E}-06$ & $1.31 \mathrm{E}-06$ \\
\hline RLWS 13 & $0.00 \mathrm{E}+00$ & $0.00 \mathrm{E}+00$ & 1.63E-04 & $0.00 \mathrm{E}+00$ & $4.35 \mathrm{E}-06$ & $1.64 \mathrm{E}-06$ \\
\hline RLWS 14 & $0.00 \mathrm{E}+00$ & $0.00 \mathrm{E}+00$ & $3.25 \mathrm{E}-05$ & $0.00 \mathrm{E}+00$ & $8.69 \mathrm{E}-07$ & $3.28 \mathrm{E}-07$ \\
\hline RLWS 15 & $0.00 \mathrm{E}+00$ & $0.00 \mathrm{E}+00$ & $5.85 \mathrm{E}-04$ & $0.00 \mathrm{E}+00$ & $1.56 \mathrm{E}-05$ & $5.91 \mathrm{E}-06$ \\
\hline RLWS 16 & $0.00 \mathrm{E}+00$ & $0.00 \mathrm{E}+00$ & $1.30 \mathrm{E}-05$ & $0.00 \mathrm{E}+00$ & $3.48 \mathrm{E}-07$ & $1.31 \mathrm{E}-07$ \\
\hline RLWS 17 & $0.00 \mathrm{E}+00$ & $0.00 \mathrm{E}+00$ & $2.60 \mathrm{E}-05$ & $0.00 \mathrm{E}+00$ & $6.95 \mathrm{E}-07$ & $2.63 \mathrm{E}-07$ \\
\hline RLWS 18 & $0.00 \mathrm{E}+00$ & $0.00 \mathrm{E}+00$ & $2.60 \mathrm{E}-05$ & $0.00 \mathrm{E}+00$ & $6.95 \mathrm{E}-07$ & 2.63E-07 \\
\hline RLWS 19 & $0.00 \mathrm{E}+00$ & $0.00 \mathrm{E}+00$ & $3.90 \mathrm{E}-04$ & $0.00 \mathrm{E}+00$ & $1.04 \mathrm{E}-05$ & $3.94 \mathrm{E}-06$ \\
\hline RLW.S 20 & $0.00 \mathrm{E}+00$ & $0.00 \mathrm{E}+00$ & $3.90 \mathrm{E}-05$ & $0.00 \mathrm{E}+00$ & $1.04 \mathrm{E}-06$ & $3.94 \mathrm{E}-07$ \\
\hline RLWS 21 & $0.00 \mathrm{E}+00$ & $0.00 \mathrm{E}+00$ & $3.25 \mathrm{E}-05$ & $0.00 \mathrm{E}+00$ & $8.69 \mathrm{E}-07$ & $3.28 \mathrm{E}-07$ \\
\hline RLWS 22 & $0.00 \mathrm{E}+00$ & $0.00 \mathrm{E}+00$ & 9.75E-05 & $0.00 \mathrm{E}+00$ & $2.61 E-06$ & $9.85 \mathrm{E}-07$ \\
\hline RLWS 23 & $0.00 \mathrm{E}+00$ & $0.00 \mathrm{E}+00$ & $1.63 \mathrm{E}-05$ & $0.00 \mathrm{E}+00$ & $4.35 \mathrm{E}-07$ & $1.64 \mathrm{E}-07$ \\
\hline RLWS 24 & $0.00 \mathrm{E}+00$ & $0.00 \mathrm{E}+00$ & $1.30 \mathrm{E}-05$ & $0.00 \mathrm{E}+00$ & $3.48 \mathrm{E}-07$ & $1.31 \mathrm{E}-07$ \\
\hline RLWS 25 & $0.00 \mathrm{E}+00$ & $0.00 \mathrm{E}+00$ & $1.30 \mathrm{E}-04$ & $0.00 \mathrm{E}+00$ & $3.48 \mathrm{E}-06$ & $1.31 \mathrm{E}-06$ \\
\hline RLWS 26 & $0.00 \mathrm{E}+00$ & $0.00 \mathrm{E}+00$ & $3.25 \mathrm{E}-05$ & $0.00 \mathrm{E}+00$ & $8.69 \mathrm{E}-07$ & $3.28 \mathrm{E}-07$ \\
\hline RLWS 27 & $0.00 \mathrm{E}+00$ & $0.00 \mathrm{E}+00$ & $1.95 \mathrm{E}-05$ & $0.00 \mathrm{E}+00$ & $5.22 \mathrm{E}-07$ & $1.97 \mathrm{E}-07$ \\
\hline RLWS 28 & $0.00 \mathrm{E}+00$ & $0.00 \mathrm{E}+00$ & $1.30 \mathrm{E}-05$ & $0.00 E+00$ & $3.48 \mathrm{E}-07$ & $1.31 \mathrm{E}-07$ \\
\hline RLWS 29 & $0.00 \mathrm{E}+00$ & $0.00 \mathrm{E}+00$ & $1.95 \mathrm{E}-05$ & $0.00 \mathrm{E}+00$ & $5.22 \mathrm{E}-07^{\circ}$ & $1.97 \mathrm{E}-07$ \\
\hline RLWS 30 & $0.00 \mathrm{E}+00$ & $0.00 \mathrm{E}+00$ & $2.60 \mathrm{E}-05$ & $0.00 \mathrm{E}+00$ & $6.95 \mathrm{E}-07$ & $2.63 \mathrm{E}-07$ \\
\hline RLWS 31 & $0.00 \mathrm{E}+00$ & $0.00 E+00$ & $1.95 \mathrm{E}-05$ & $0.00 \mathrm{E}+00$ & $5.22 \mathrm{E}-07$ & 1:97E-07 \\
\hline
\end{tabular}




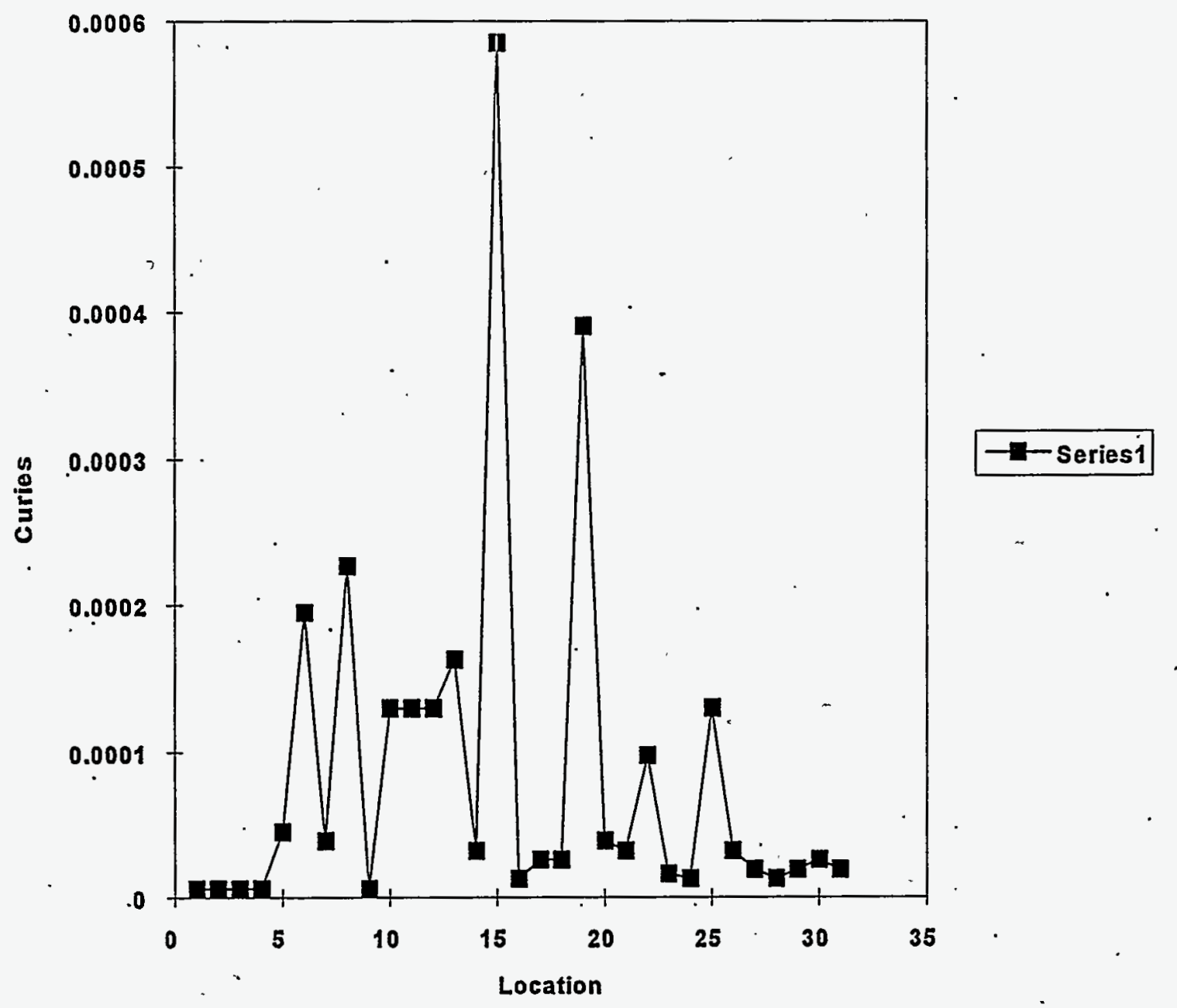

Figure 5.1. Cesium-137 Found in RLWS Lines (by RLWS Number), Curies 
Table 5.6. Radioactive Liquid Waste System Pipeline Activity Profile, Curies

\begin{tabular}{|c|c|c|c|c|c|c|}
\hline Location & ${ }^{241} \mathrm{Am}$ & ${ }^{239} \mathrm{Pu}$ & ${ }^{137} \mathrm{Cs}$ & ${ }^{152} \mathrm{Eu}$ & ${ }^{154} \mathrm{Eu}$ & ${ }^{60} \mathrm{Co}$ \\
\hline \multicolumn{7}{|c|}{ Laboratory Vacuum System Line } \\
\hline E5 & 8.12E-04 & $0.00 \mathrm{E}+00$ & $4.45 \mathrm{E}-06$ & $1.31 \mathrm{E}-06$ & $2.90 \mathrm{E}-06$ & $0.00 \mathrm{E}+00$ \\
\hline F5 & $9.64 \mathrm{E}-03$ & $0.00 \mathrm{E}+00$ & $8.21 \mathrm{E}-05$ & $3.61 \mathrm{E}-06$ & $8.95 \mathrm{E}-06$ & $0.00 \mathrm{E}+00$ \\
\hline C6 & $1.69 \mathrm{E}-03$ & $0.00 \mathrm{E}+00$ & $3.63 \mathrm{E}-05$ & $0.00 \mathrm{E}+00$ & $4.74 \mathrm{E}-07$ & $0.00 \mathrm{E}+00$ \\
\hline $\mathrm{H} 6$ & $2.28 \mathrm{E}-03$ & $0.00 \mathrm{E}+00$ & 2.24E-05 & 2.34E-06 & $5.69 \mathrm{E}-06$ & $0.00 \mathrm{E}+00$ \\
\hline $\mathrm{HS}(45-9)$ & $6.83 \mathrm{E}-03$ & $0.00 \mathrm{E}+00$ & $5.22 \mathrm{E}-04$ & $1.56 \mathrm{E}-05$ & 4.25E-04 & $0.00 \mathrm{E}+0 \mathrm{C}$ \\
\hline B416H4 & $0.00 \mathrm{E}+00$ & $0.00 \mathrm{E}+00$ & 5.23E-07 & $0.00 \mathrm{E}+00$ & $0.00 \mathrm{E}+00$ & $6.15 \mathrm{E}-08$ \\
\hline B416H2 & $0.00 \mathrm{E}+00$ & $0.00 \mathrm{E}+00$ & $4.56 \mathrm{E}-07$ & $0.00 \mathrm{E}+00$ & $0.00 \mathrm{E}+00$ & $0.00 \mathrm{E}+00$ \\
\hline $\mathrm{B} 416 \mathrm{H} 1$ & $0.00 \mathrm{E}+00$ & $0.00 \mathrm{E}+00$ & $3.16 \mathrm{E}-07$ & $0.00 \mathrm{E}+00$ & $\cdot 0.00 \mathrm{E}+00$ & $2.28 \mathrm{E}-07$ \\
\hline \multicolumn{7}{|c|}{ Plenum Duct "Hot Spot" } \\
\hline PLEN-HS & $0.00 \mathrm{E}+00$ & $0.00 \mathrm{E}+00$ & $1.37 \mathrm{E}-04$ & $0.00 \mathrm{E}+00$ & $2.50 \mathrm{E}-06$ & $0.00 \mathrm{E}+00$ \\
\hline $303-\mathrm{H} 4$ & $0.00 \mathrm{E}+00$ & $0.00 \mathrm{E}+00$ & $0.00 \mathrm{E}+00$ & $0.00 \mathrm{E}+00$ & $0.00 \mathrm{E}+00$ & $0.00 \mathrm{E}+00$ \\
\hline $309-\mathrm{H} 2$ & $0.00 \mathrm{E}+00$ & $0.00 \mathrm{E}+00$ & $1.29 \mathrm{E}-05$ & $0.00 \mathrm{E}+00$ & $0.00 \mathrm{E}+00$ & $0: 00 \mathrm{E}+00$ \\
\hline 309-H6 & $1.07 \mathrm{E}-05$ & $0.00 \mathrm{E}+00$ & 4.47E-05 & $0.00 \mathrm{E}+00$ & $0.00 \mathrm{E}+00$ & $1.25 E-07$ \\
\hline 313-H4 & $0.00 \mathrm{E}+00$ & $0.00 \mathrm{E}+00$ & $0.00 \mathrm{E}+00$ & $0.00 \mathrm{E}+00$ & $0.00 \mathrm{E}+00$ & $0.00 \mathrm{E}+00$ \\
\hline $317-\mathrm{H} 1$ & $0.00 \mathrm{E}+00$ & $0.00 \mathrm{E}+00$ & $0.00 \mathrm{E}+00$ & $0.00 \mathrm{E}+00$ & $0.00 \mathrm{E}+00$ & $0.00 \mathrm{E}+00$ \\
\hline $317-\mathrm{H} 2$ & $0.00 \mathrm{E}+00$ & $0.00 \mathrm{E}+00$ & $0.00 E+00$ & $0.00 \mathrm{E}+00$ & $0.00 \mathrm{E}+00$ & $0.00 \mathrm{E}+00$ \\
\hline $500-\mathrm{H} 1$ & $0.00 \mathrm{E}+00$ & $0.00 \mathrm{E}+00$ & 7.69E-05 & $0.00 \mathrm{E}+00$ & $4.93 E-07$ & $2.54 \mathrm{E}-07$ \\
\hline $500-\mathrm{H} 2$ & $0.00 \mathrm{E}+00$ & $0.00 \mathrm{E}+00$ & $0.00 \mathrm{E}+00$ & $0.00 \mathrm{E}+00$ & $0.00 \mathrm{E}+00$ & $0.00 \mathrm{E}+00$ \\
\hline 504-H1 & $4.21 E-05$ & $4.23 \mathrm{E}-01$ & $1.19 E-04$ & $0.00 \mathrm{E}+00$ & $3.39 E-07$ & $5.12 \mathrm{E}-07$ \\
\hline $506-\mathrm{H} 3$ & $0.00 \mathrm{E}+00$ & 4.61E-02 & $2.78 \mathrm{E}-06$ & $0.00 \mathrm{E}+00$ & $0.00 \mathrm{E}+00$ & $0.00 \mathrm{E}+00$ \\
\hline $510-\mathrm{H} 3$ & $0.00 \mathrm{E}+00$ & $0.00 \mathrm{E}+00$ & $5.06 \mathrm{E}-06$ & $0.00 \mathrm{E}+00$ & $0.00 \mathrm{E}+00$ & $0.00 \mathrm{E}+00$ \\
\hline \multirow[t]{2}{*}{$528-\mathrm{H} 4$} & $0.00 \mathrm{E}+00$ & $0.00 \mathrm{E}+00$ & $2.70 \mathrm{E}-07$ & $0.00 \mathrm{E}+00$ & $0.00 \mathrm{E}+00$ & $2.43 E-07$ \\
\hline & $0.00 \mathrm{E}+00$ & $0.00 \mathrm{E}+00$ & $0.00 \mathrm{E}+00$ & $0.00 \mathrm{E}+00$ & $0.00 \mathrm{E}+00$ & $0.00 \mathrm{E}+00$ \\
\hline
\end{tabular}

Glove Boxes

\begin{tabular}{|c|c|c|c|c|c|c|}
\hline 305-GB3 & $4.89 \mathrm{E}-04$ & $1.22 \mathrm{E}-01$ & $1.01 \mathrm{E}-05$ & $1.52 \mathrm{E}-06$ & $2.30 \mathrm{E}-06$ & 9.22E-07 \\
\hline $305-G B 6$ & $1.80 \mathrm{E}-05$ & $9.07 \mathrm{E}-02$ & $6.73 \mathrm{E}-07$ & $0.00 \mathrm{E}+00$ & $0.00 \mathrm{E}+00$ & $0.00 \mathrm{E}+00$ \\
\hline 05-GB7 & $1.16 \mathrm{E}-05$ & $0.00 \mathrm{E}+00$ & $1.36 \mathrm{E}-07$ & $0.00 \mathrm{E}+00$ & $0.00 \mathrm{E}+00$ & $.00 \mathrm{E}+00$ \\
\hline 106-GB3 & $3.30 \mathrm{E}-04$ & $0.00 \mathrm{E}+00$ & $1.65 \mathrm{E}-04$ & $0.00 \mathrm{E}+00$ & $2.50 \mathrm{E}-07$ & $0.00 E+00$ \\
\hline 406-GB4 & 2.15E-03 & $8.96 \mathrm{E}-02$ & $3.82 E-04$ & $0.00 \mathrm{E}+00$ & $4.19 \mathrm{E}-07$ & $0.00 \mathrm{E}+00$ \\
\hline 406-GB5 & $1.54 \mathrm{E}-03$ & $1.53 \mathrm{E}-01$ & $9.52 \mathrm{E}-06$ & $.00 \mathrm{E}+00$ & $0.00 \mathrm{E}+00$ & $.00 E+00$ \\
\hline 106-GB6 & $5.14 \mathrm{E}-03$ & 7.79E-02 & $3.91 \mathrm{E}-05$ & $0.00 \mathrm{E}+00$ & $0.00 \dot{\mathrm{E}}+00$ & $0.0-0 \mathrm{E}+00$ \\
\hline $506-\mathrm{GB} 1$ & 4.01E-04 & $0.00 \mathrm{E}+00$ & $5.95 \mathrm{E}-05$ & $0.00 \mathrm{E}+00$ & $0.00 \mathrm{E}+00$ & $2.53 \mathrm{E}-07$ \\
\hline 6-GB4 & $0.00 \mathrm{E}+00$ & $0.00 \mathrm{E}+00$ & $0.00 \mathrm{E}+00$ & $0.00 \mathrm{E}+00$ & $0.00 \mathrm{E}+00$ & $0.00 \mathrm{E}+00$ \\
\hline $28-G B 2$ & $1.16 \mathrm{E}-04$ & $2.69 \mathrm{E}-02$ & $4.42 \mathrm{E}-06$ & $0.00 \mathrm{E}+00$ & $0.00 E+00$ & $0.00 \mathrm{E}+00$ \\
\hline 528-GB3 & $1.80 \mathrm{E}-04$ & $3.80 \mathrm{E}-02$ & $6.27 \mathrm{E}-06$ & $0.00 \mathrm{E}+00$ & $0.00 \mathrm{E}+00$ & $0.00 \mathrm{E}+00$ \\
\hline
\end{tabular}




\subsection{References}

Brackenbush, L. W., and L.,G. Faust. 1970. Neutron Spectra of Plutonium Compounds. BNW-1262, Battelle Northwest, Richland, Washington.

Brackenbush, L. W., W. D. Reece, and J. E. Tanner. 1984. Neutron Dosimetry at Commercial Nuclear Plants. NUREG/CR-3610, U.S. Nuclear Regulatory Commission, Washington, D.C.

Los Alamos National Laboratory (LANL). 1992. Nuclear Safeguards Training Program: "Nondestructive Assay of Special Nuclear Materials Holdup" (presented May 4-8, 1992) and "Nondestructive Assay Techniques for Safeguards Practitioners" (presented August 10-14, 1992). Los Alamos National Laboratory, Los Alamos, New Mexico.

Reilly, D., N. Ensslin, and H. Smith, Jr. 1991. Passive Nondestructive Assay of Nuclear Materials. NUREG/CR, LA-UR-732, U.S. Nuclear Regulatory Commission, Washington, D.C.

Schwartz, R. B., and C. M. Eisenhauer. 1982. Procedures for Calibrating Neutron Personnel Dosimeters. NBS Special Publication 633, National Bureau of Standards, Washington, D.C.

Stoddard, D. H., and H. E. Hootman. 1971. ${ }^{252} \mathrm{CfShielding} \mathrm{Guide.} \mathrm{E.} \mathrm{I.} \mathrm{DuPont} \mathrm{de} \mathrm{Nemours,} \mathrm{Aiken,}$ South Carolina.

U.S. Nuclear Regulatory Commission (NRC). 1983. In Situ Assay of Enriched Uranium Residual Holdup. U.S. Nuclear Regulatory Guide 5.37, U.S. Nuclear Regulatory Commission, Washington, D.C.

U.S. Nuclear Regulatory Commission (NRC). 1984. In Situ Assay of Plutonium Residual Holdup. U.S. Nuclear Regulatory Guide 5.23, U.S. Nuclear Regulatory Commission, Washington, D.C. 
Appendix A

Basic Holdup Assay Measurements Procedure MCA-510 


\section{Appendix A.}

\section{Basic Holdup Assay Measurements Procedure MCA-510}

1. The assay system components are set up in the laboratory and pretest verifications are performed.

2. Perform energy calibration and measurement control procedure, completing Exhibit A (see Figure A.1).

3. Perform calibrations for the assay scenario.

4. Move instrumentation to location and verify that no damage has occurred. Perform an energy calibration and measurement control procedure, completing Exhibit $\mathrm{A}$.

5. Determine ambient background(s) at the counting location and evaluate counting technique(s).

6. Perform measurements with intermittent control checks, record data and location, and assign nondestructive assay (NDA) log numbers.

7. Transfer data and analyze, using software acquisition and analyses codes and computer spreadsheets. Retain the original data for archive, logging the file name on the Exhibit B, Pacific Northwest Laboratory (PNL) NDA Analysis Log/Report (see Figure A.2).

8. Evaluate the data results and determine the appropriate correction factors, including the detector filters. Initial basic assumptions are made of the source material, one being that the sample self-attenuation is negligible. Actual attenuation correction factors can be applied after measurements are made and more reasonable assumptions are determined as to the material matrix and configuration. All counts measured are corrected by the attenuation correction factors (CF).

Generally, a density value in grams per cubic centimeter $\left(\mathrm{g} / \mathrm{cm}^{3}\right)$ is derived for the item based on gross weight of the container minus the container weight and/or shielding and/or packaging materials. This matrix density value is used for the attenuation corrections for the gamma energies measured.

9. Perform the analysis, review the results, and issue a report. 
PNL NONDESTRUCTIVE ASSAY MEASUREMENT PROCEDURE

Procedure No.: NDA.510 Revision: I Effective Date: July 26, 1994 Page 31 of 34

\section{EXIIBIT A}

\section{$M$ \& TE SET-UP AND MCA ENERGY CAIIBRATION CHECKIIST}

Date

Lociation

Work Pkg \#

Operater

Time

List Assayed Items(s) and NDA Log \#:
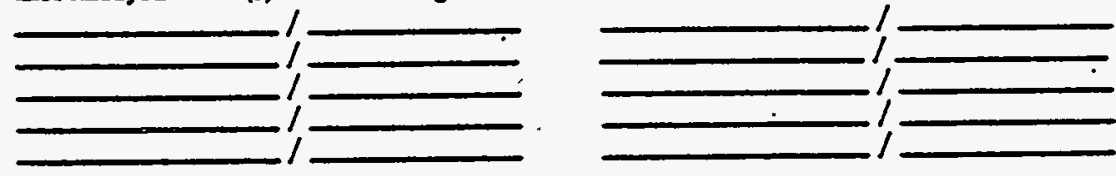

SET-UP CHECKLIST

(1) Review RWP, CSP

(2) Gamma Detector Filled With LN, Stabilized

(3) Fiters on Detectior $\mathrm{Y} / \mathrm{N}$ List

(4) Gamma Detector \#

(5) HV Supply Sertings; Pos

(G) Neutron Detector Mod/Ser.

(7) HV Supply Sertings; Pos.

ENERGT CAIIBRATION

(7) Spectroseopy Amplifier Settings:

Model No.

Course Gain

Threshold

Polarity Input

Polarity Output

Shaping Time

Fine Gair

Shapiag Multiplier

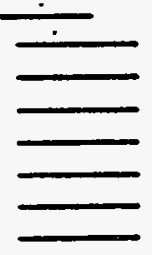

Neg

Neg $\mathrm{Neg}$

(8) Enerwo of Soures \& Peak Settings

${ }^{60} \mathrm{Co}, 13325 \mathrm{kev}$.

${ }^{237} \mathrm{Cs}, 6620 \mathrm{kev}$

${ }^{152} \mathrm{En}, 344.0 \mathrm{kev}$

ISE. $2650 \mathrm{keV}$

${ }^{25 \mathrm{Eu}}, 1275.0 \mathrm{kev}$

${ }^{133} \mathrm{Ba}, 81.0 \mathrm{kev}$

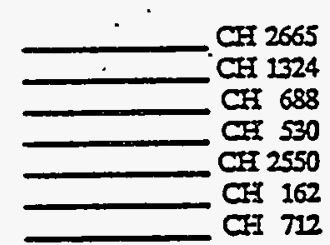

${ }^{133} \mathrm{Bz}, 356.0 \mathrm{kev}$

$\begin{aligned} & 30 \text { Model/Serial No. } \\ & \text { Gain } \frac{4096}{4096} \\ & \text { NEG } \text { Range Digital Off Set NONE } \\ & \text { POS } \text { Coincidence Gate II NONE }\end{aligned}$

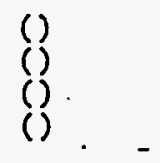

(9) Systems Adjustments and Moise. With Oscilloscope at $10 \mu \mathrm{sec} / \mathrm{dip}$ ()

Check Pole Zero

Check Peak Shape

()

2 resec

(11) MCA Identirieation

1

Model/Serial No.

(12) Neutron System

Model/Serial No.

Counter Model/Serial No.

Threshold Setting

(13) Gamma Measurement Control

Initial PreTest

Peak Energy

Count Time

$\longrightarrow$

Fioal Post Test

Peak Energy

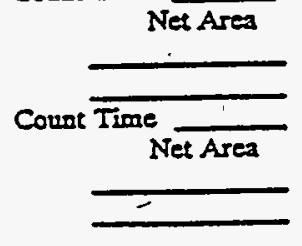

SPECIALIST REVIEW/DATE

Figure A.1. Calibration Checklist 


\section{EXHIBIT B}

\section{PNL NDA ANAIYSIS ASSAY LOG/REPORT}

DATE:

TRU

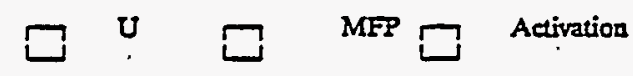

MEASUREMENT SYSTEMS/METHODS:

NDA. LOG \#

SAMPLE \#

WEIGLTT \#/G

Gamma Energy Analysis GEA

Calorimeter

- Gamma Isotopics

Passive Neutron Coincidence Well Countiog

- Active Neutron Well Counting

Passive Neutron Counting / Spectrometry

- Segmented Gamma Assay (Transmission Corrected)

- Combined Neutron Coincidence/Segmented Gamma Assay (Transmission Corrected)

- Far Field Assay Techniques

Barrels

Process Fold-up, HEPA Fiters

Waste Boxes

Project Specific

-Other

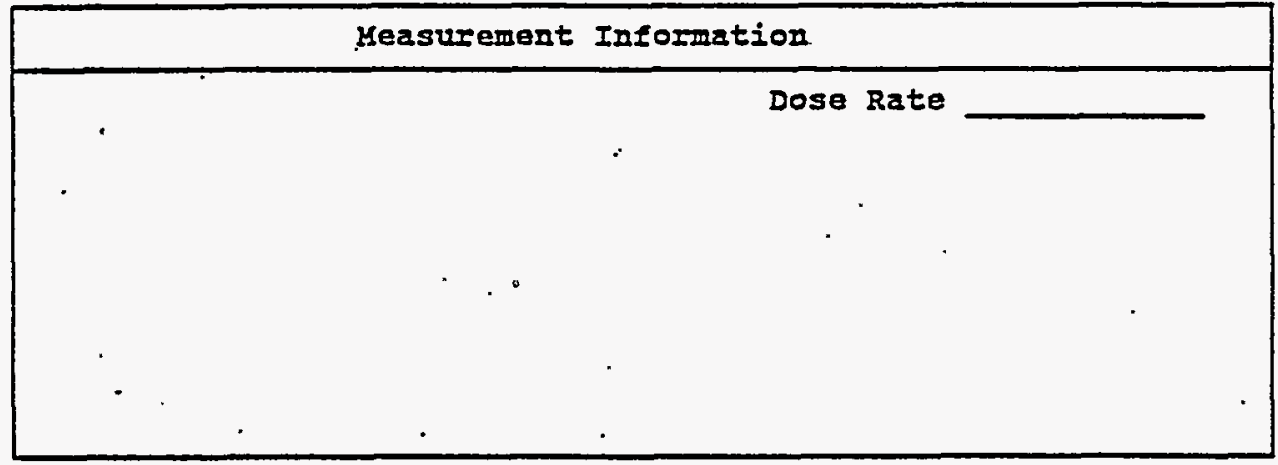

\begin{tabular}{|c|c|c|}
\hline ASSAY RESULTS: & $\begin{array}{l}\text { Report attached } \\
\text { ISOVER Report }\end{array}$ & $\begin{array}{l}Y / N \text { Issue Date } \\
Y / N \text { Issue Date }\end{array}$ \\
\hline
\end{tabular}

DATA ARCHIVED: Disk(s) Directory / Prelix

File Names

Specialist Review
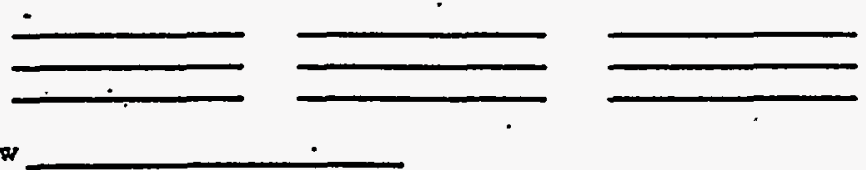

Figure A.2. Assay Log/Report Form 
Appendix B

Schematics of NDA Measurement Locations 


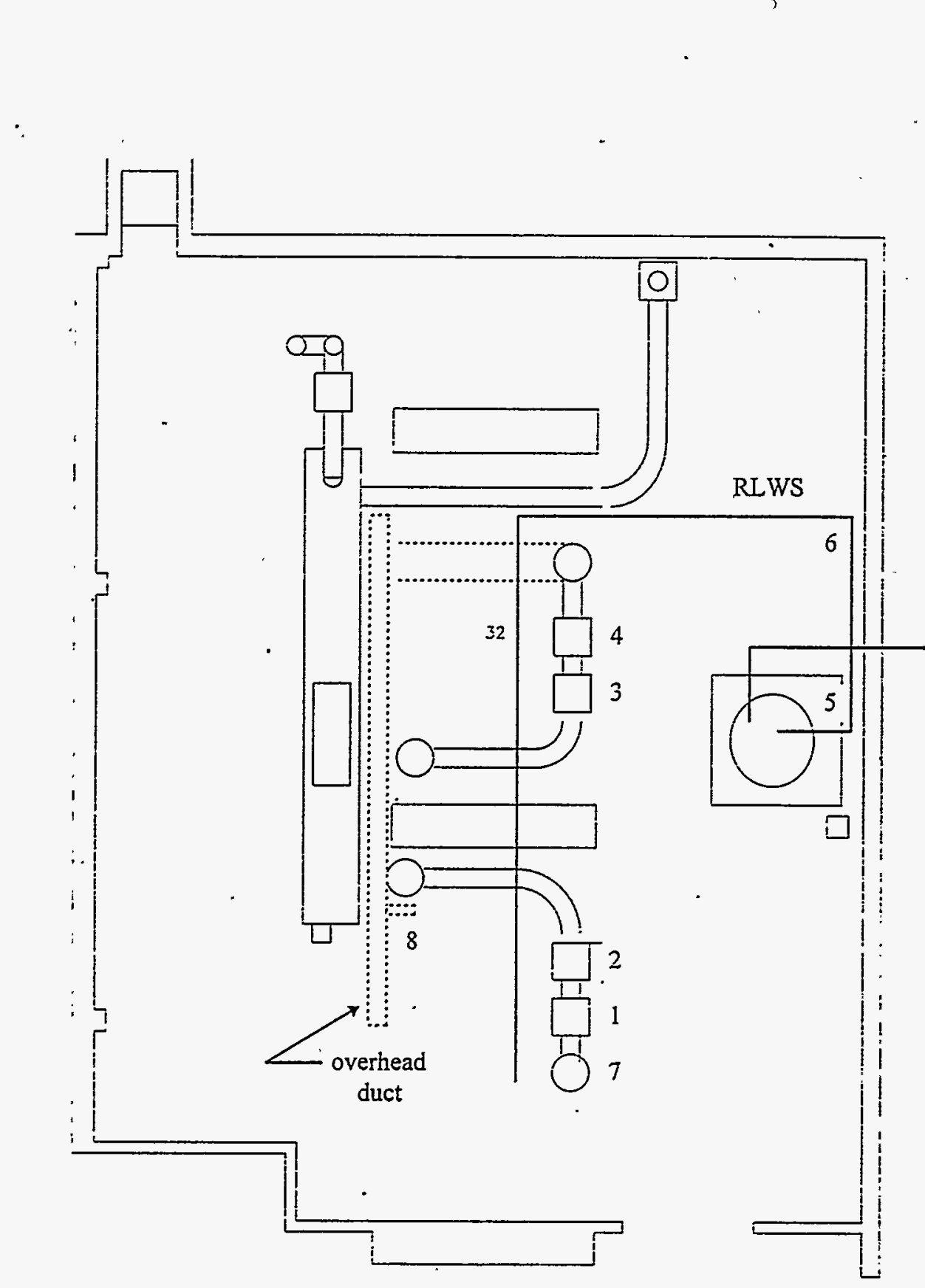

B. 1 


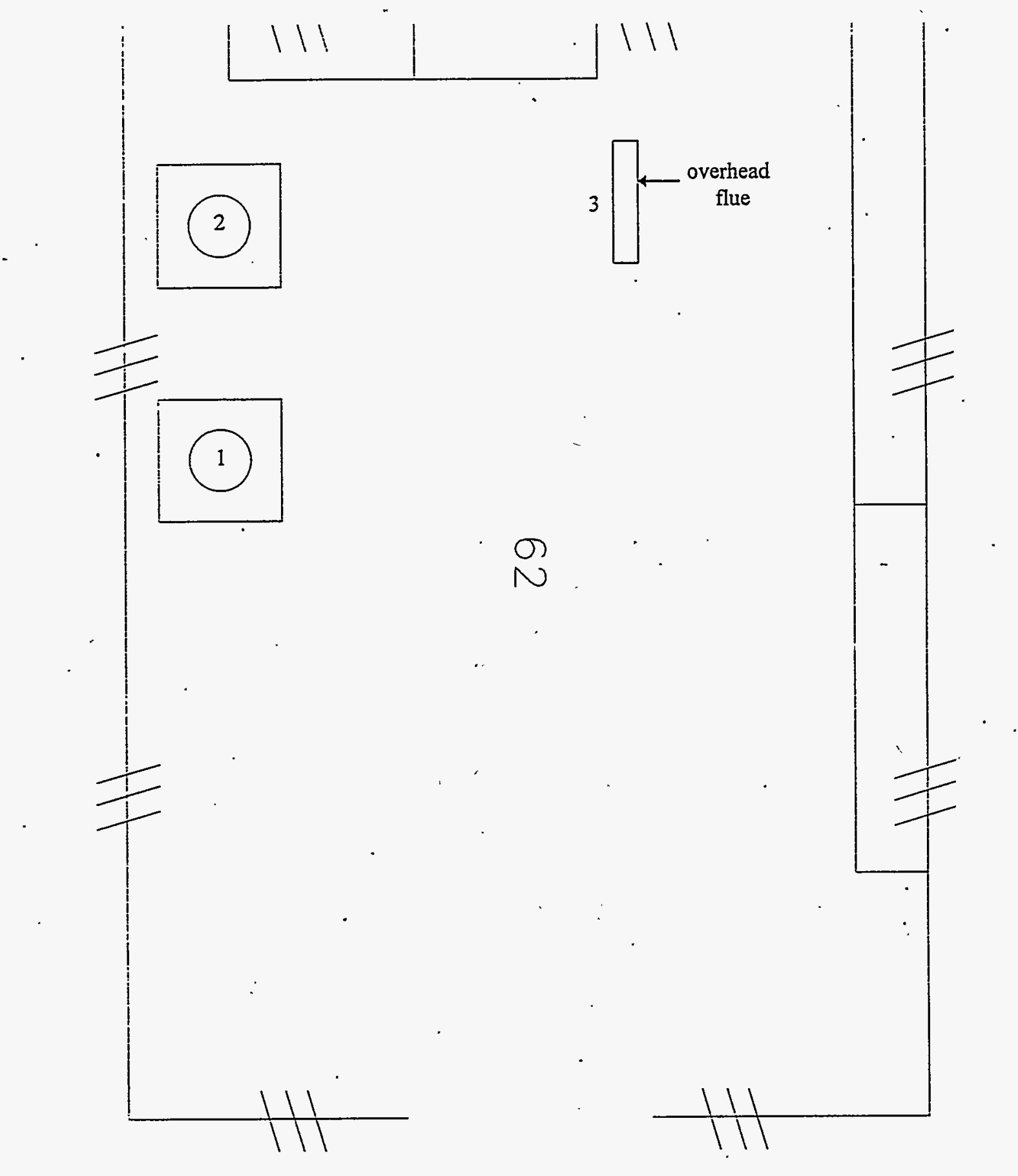

B. 2 


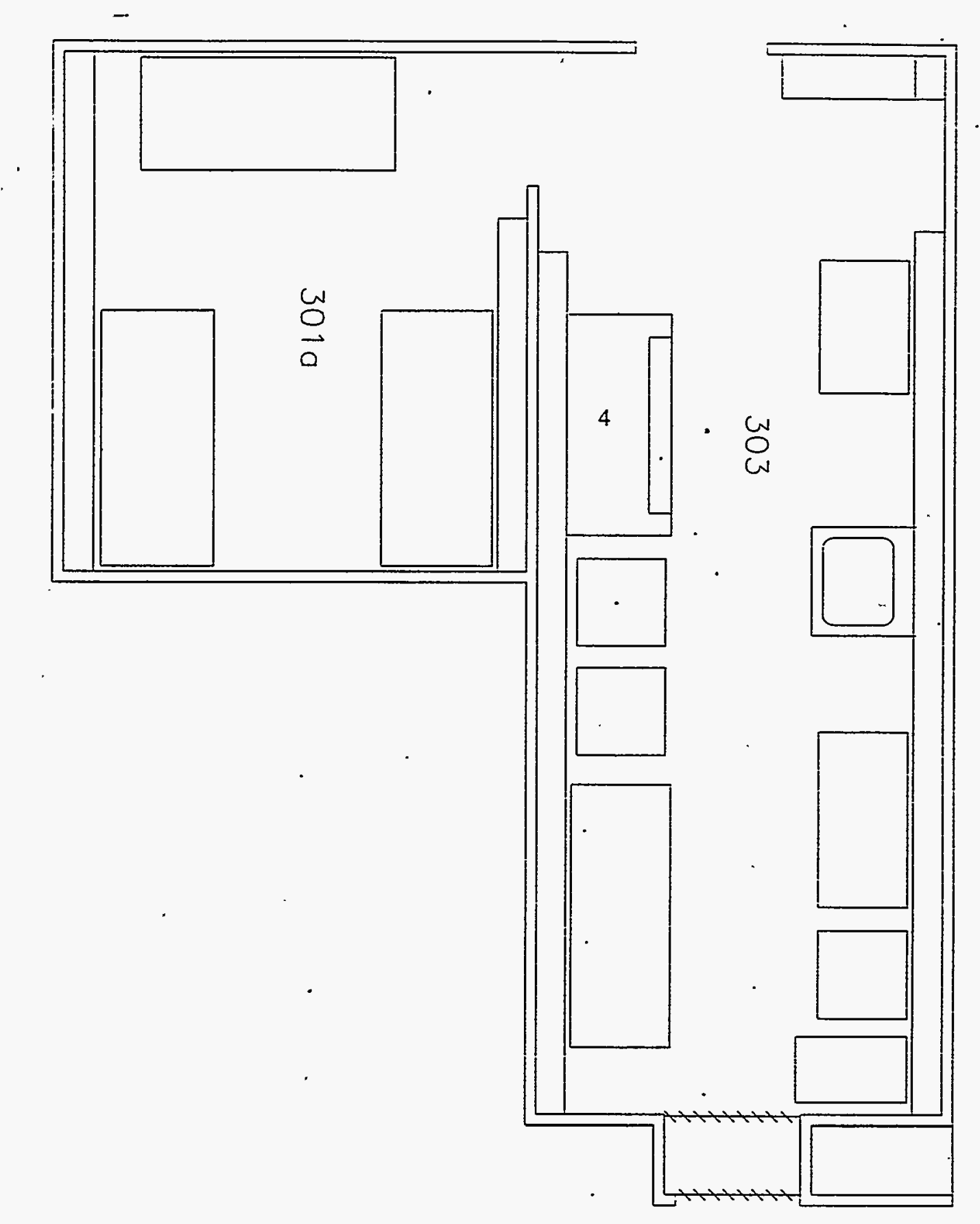




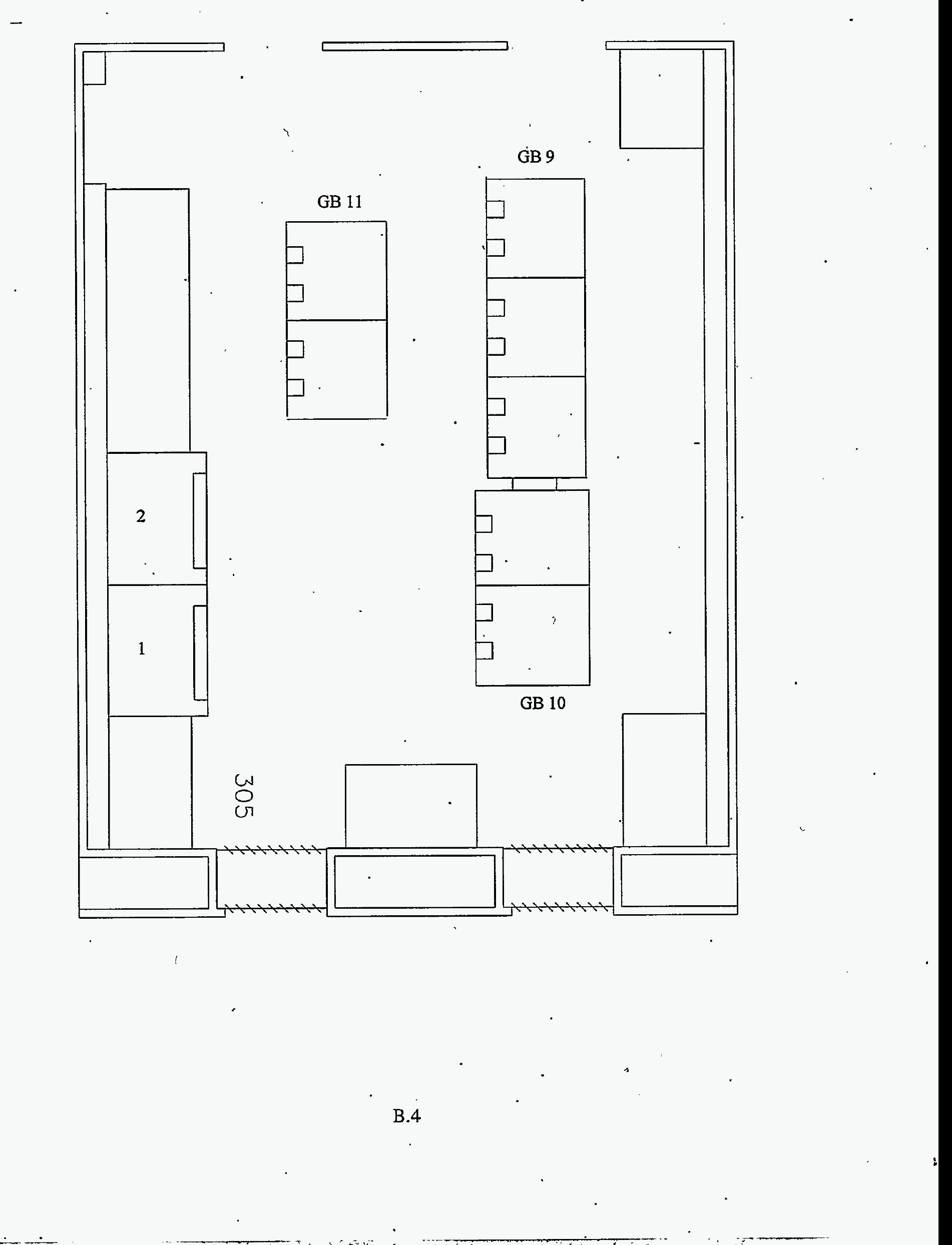




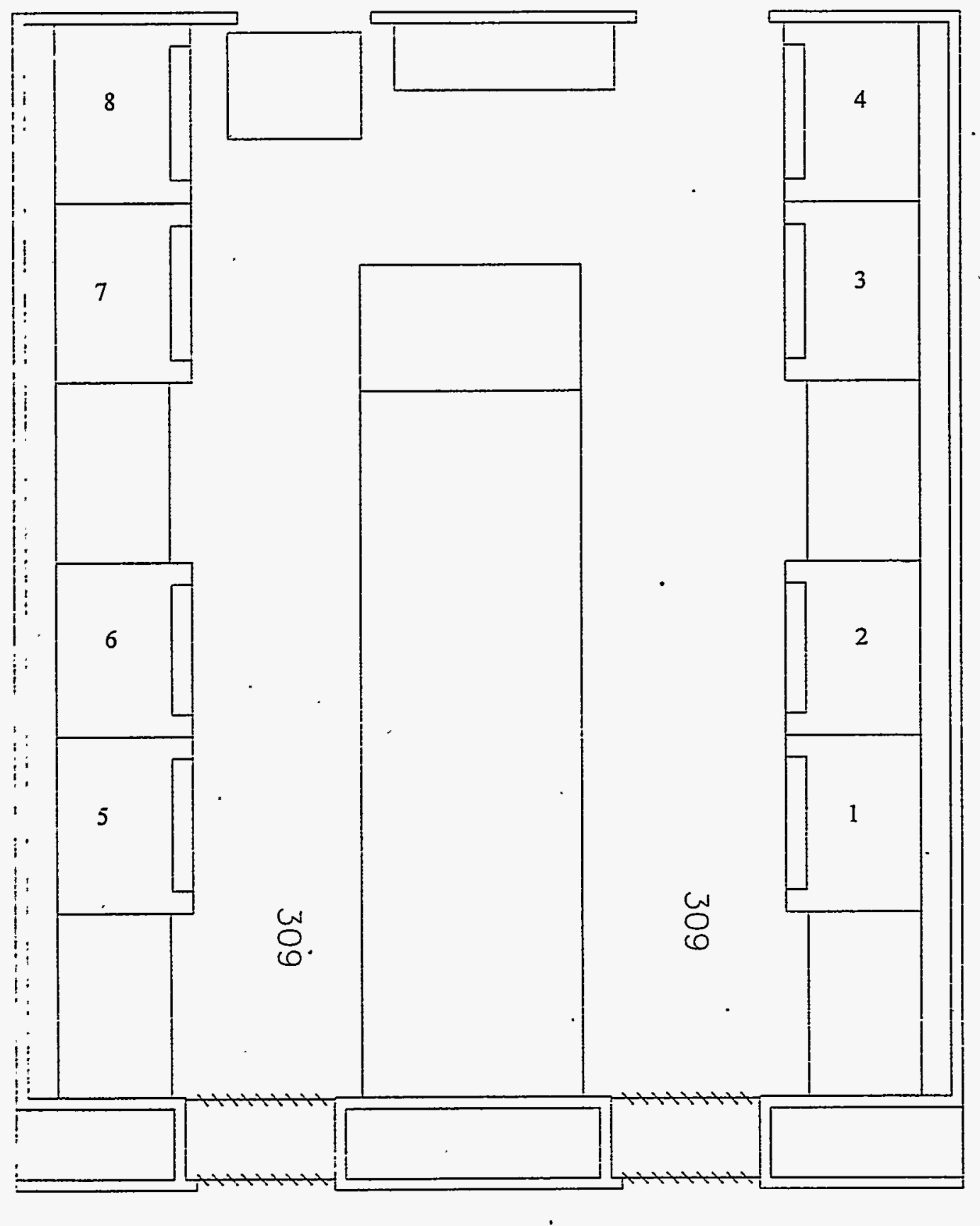

B. 5 


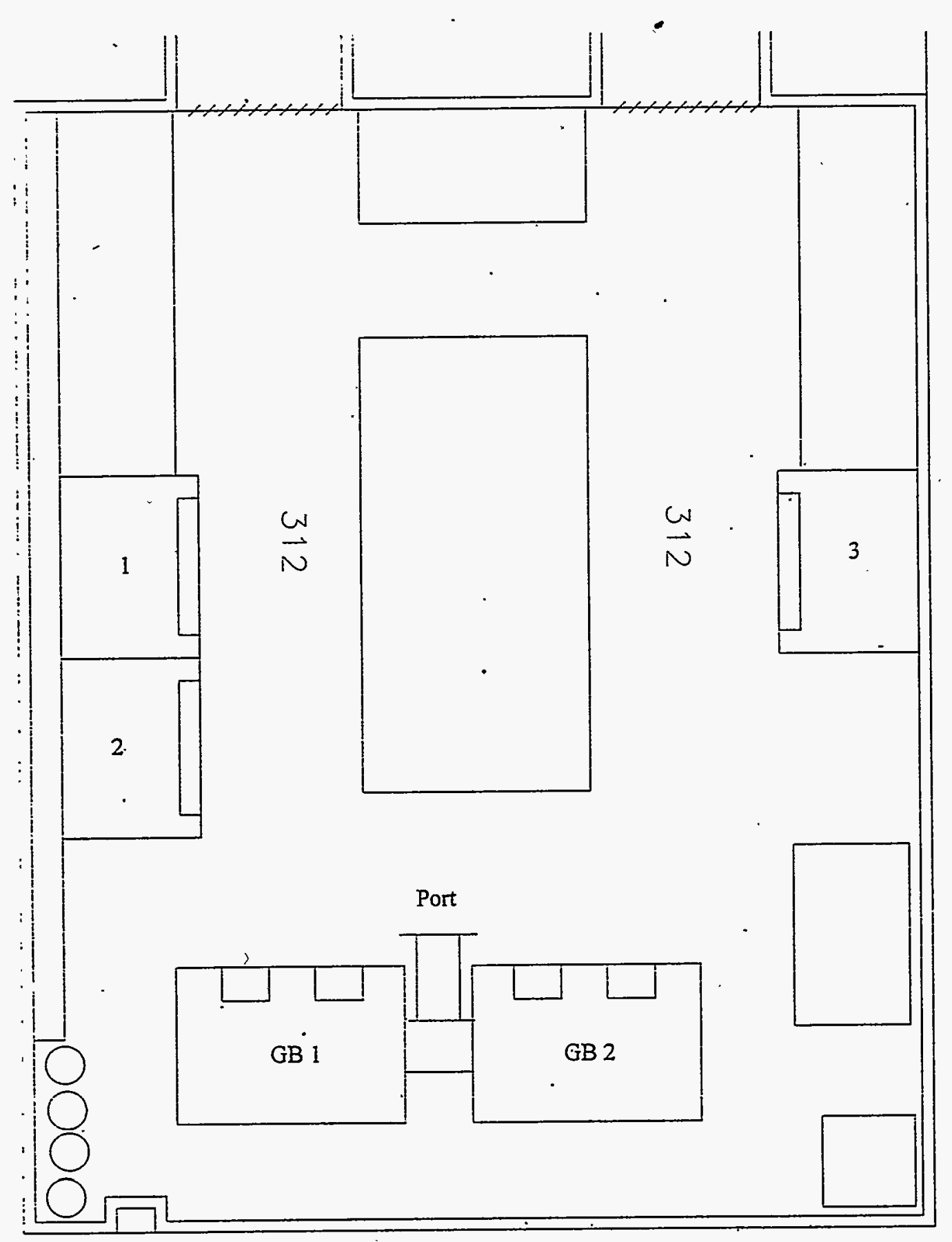

B. 6 - 


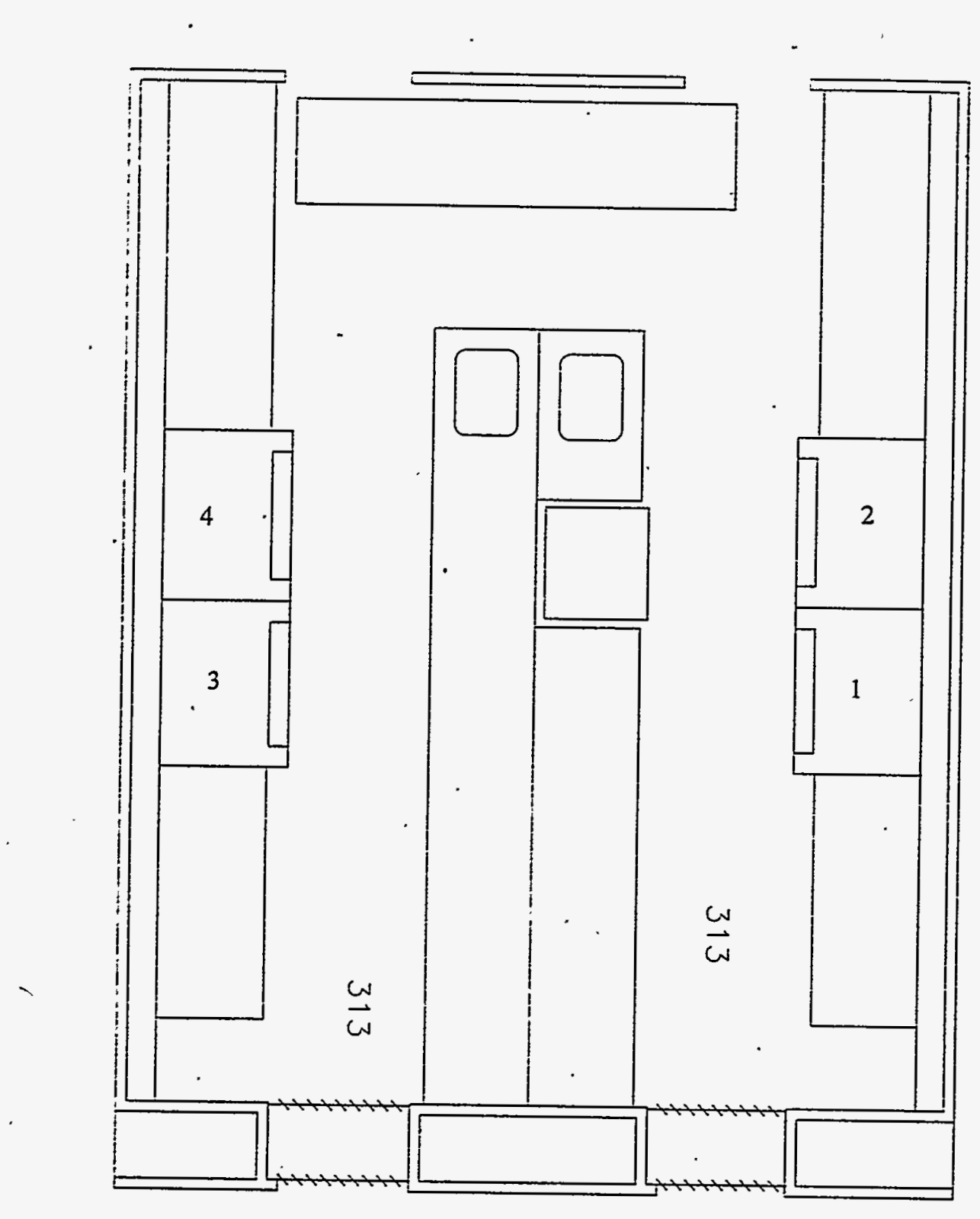

B. 7 


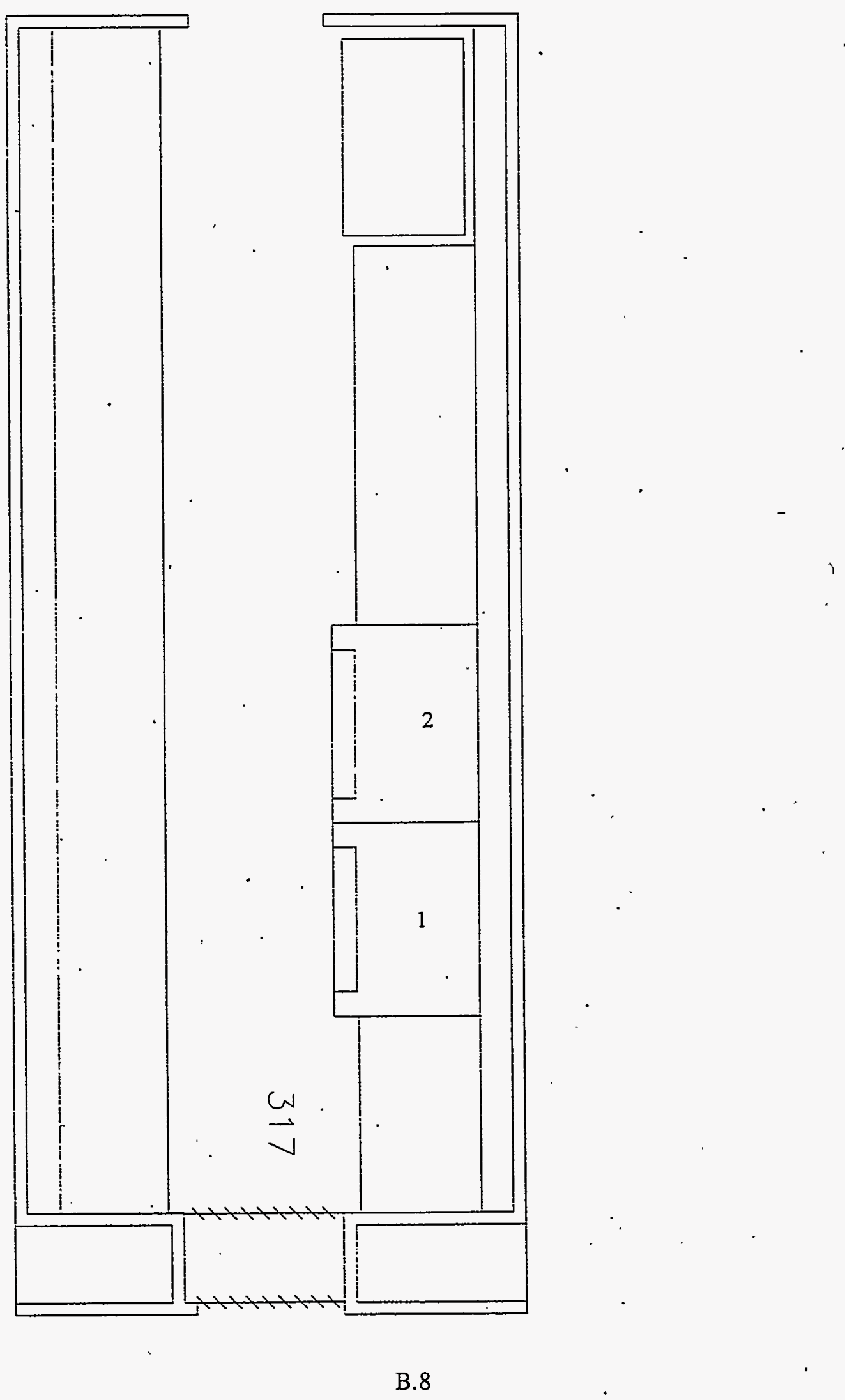



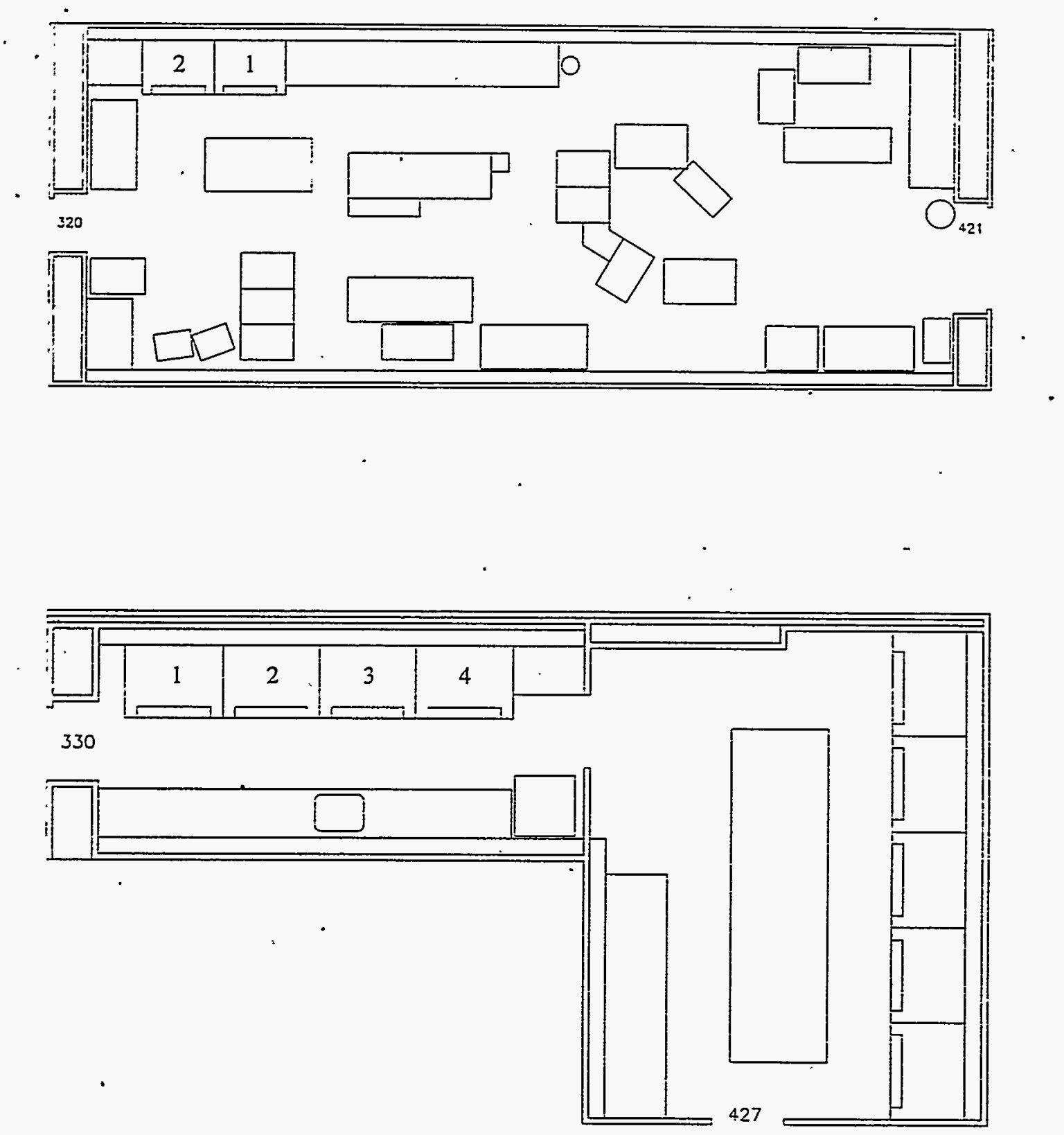

B. 9 


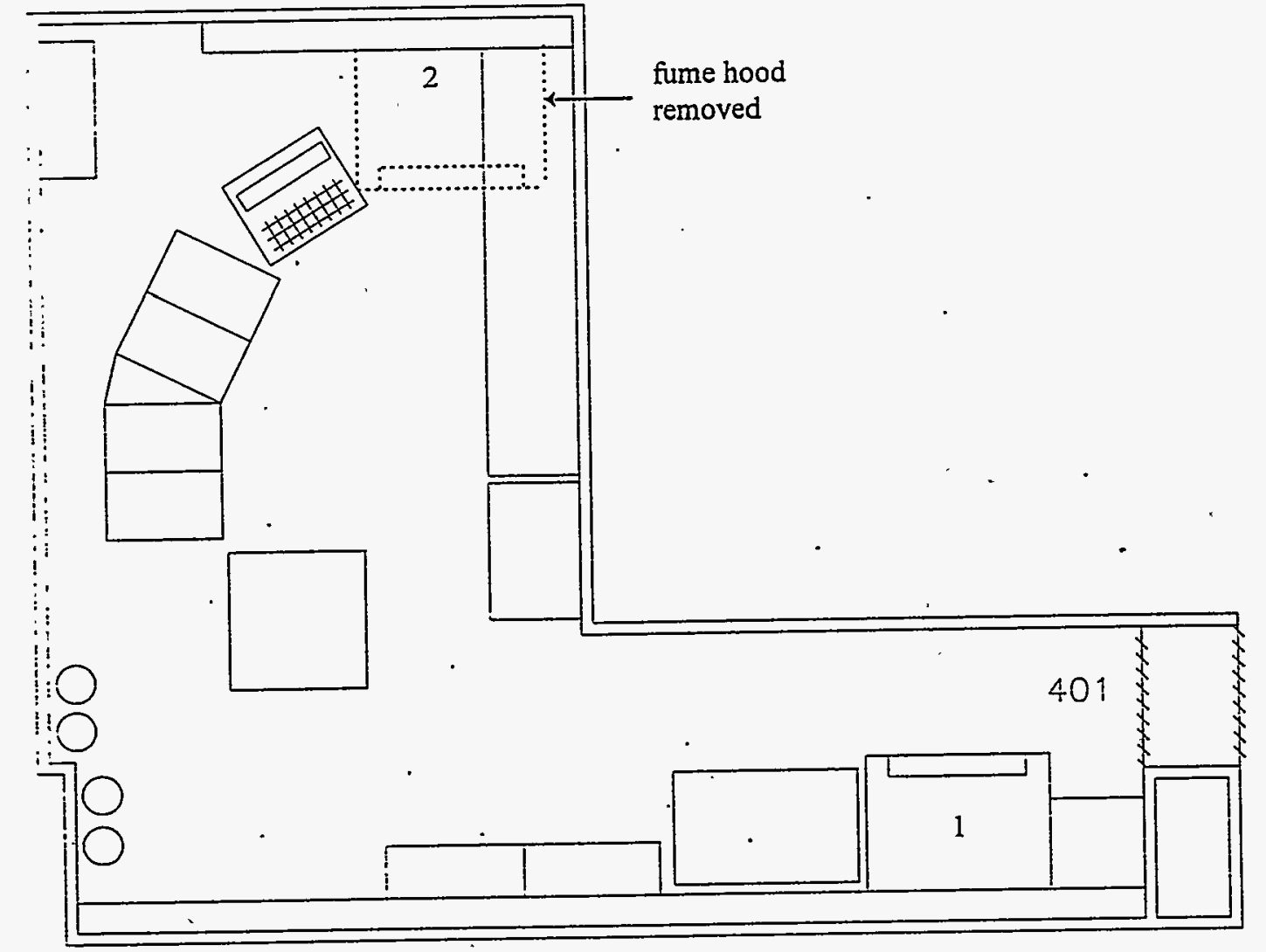

B. 10 


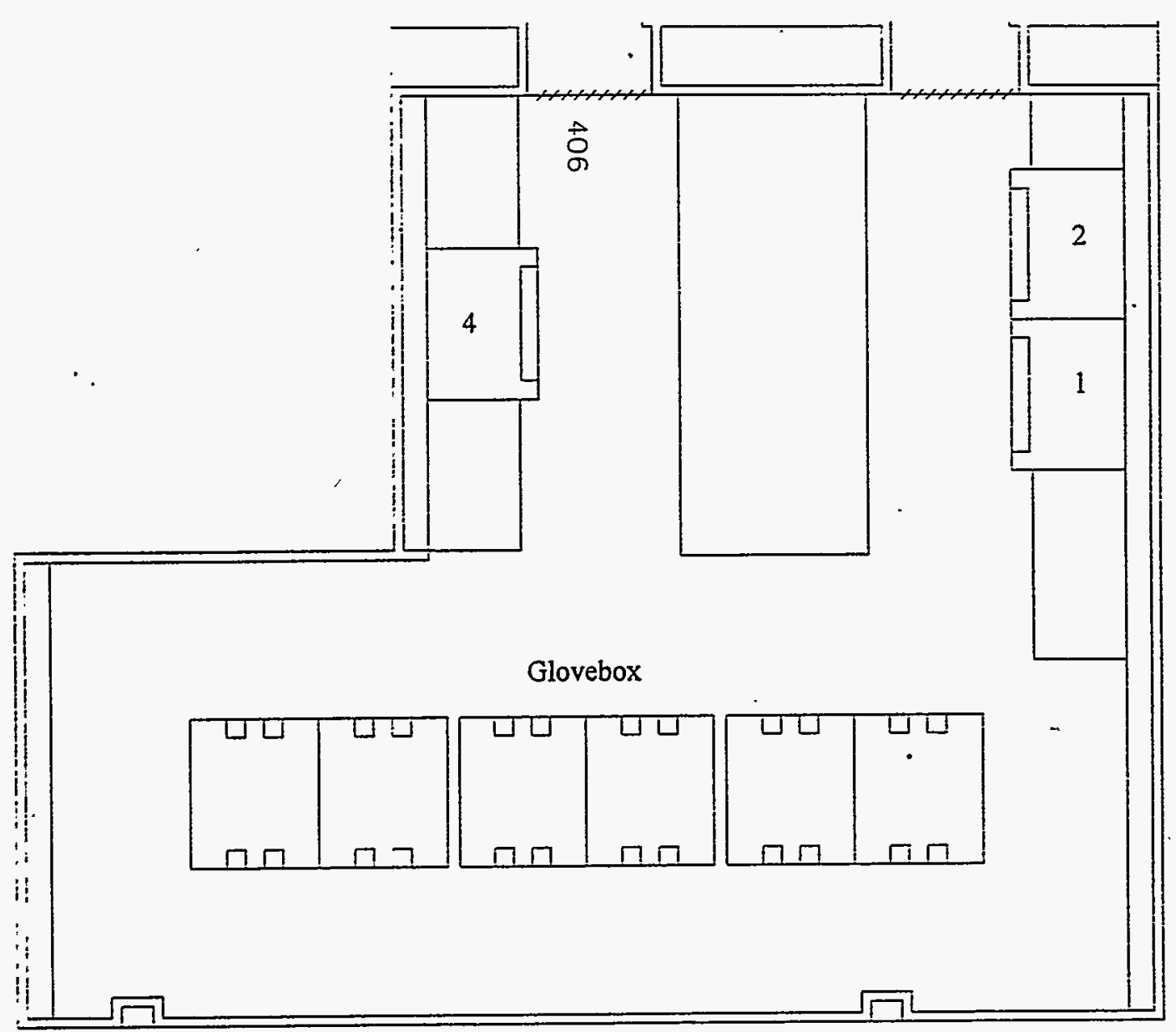




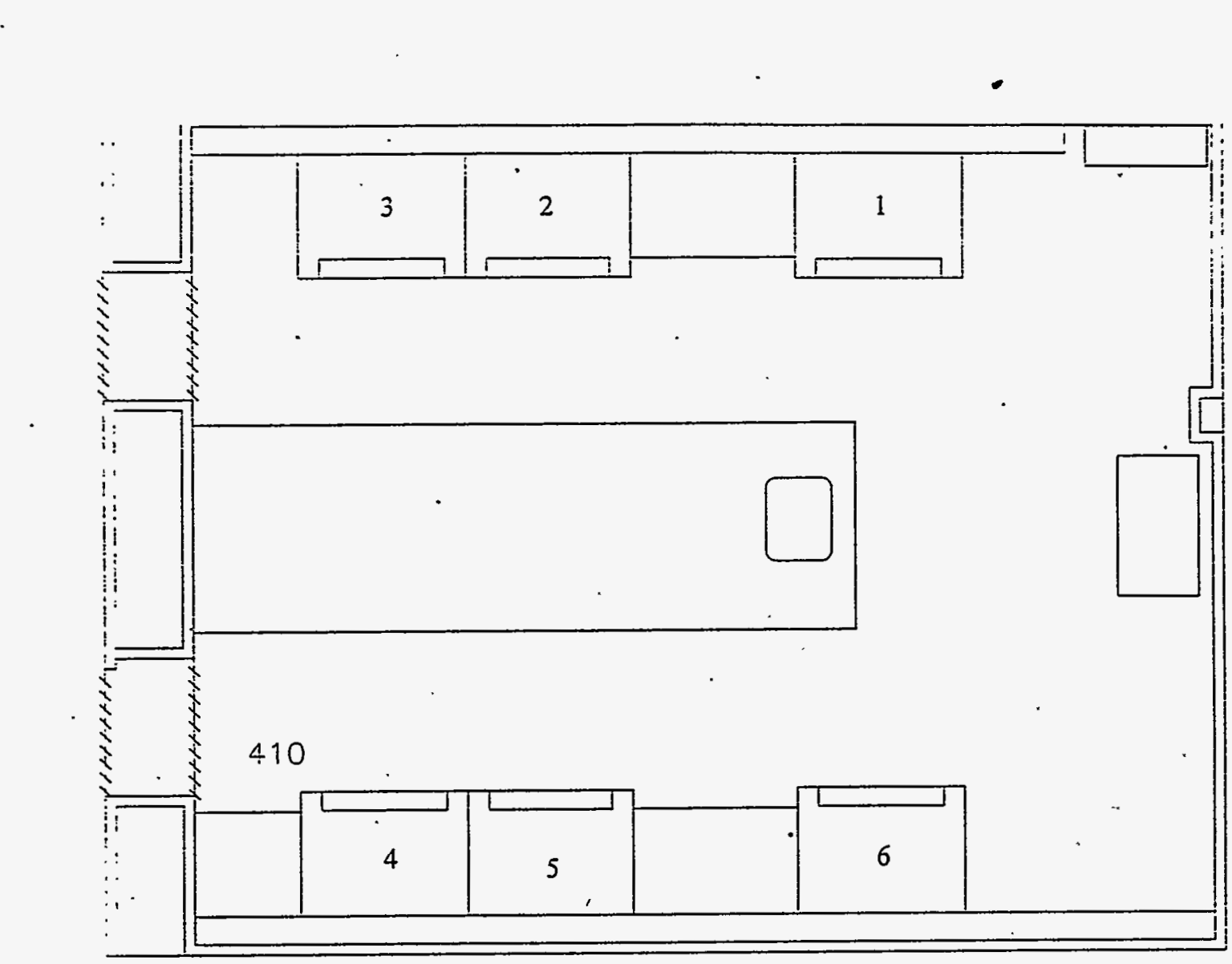

B. 12 


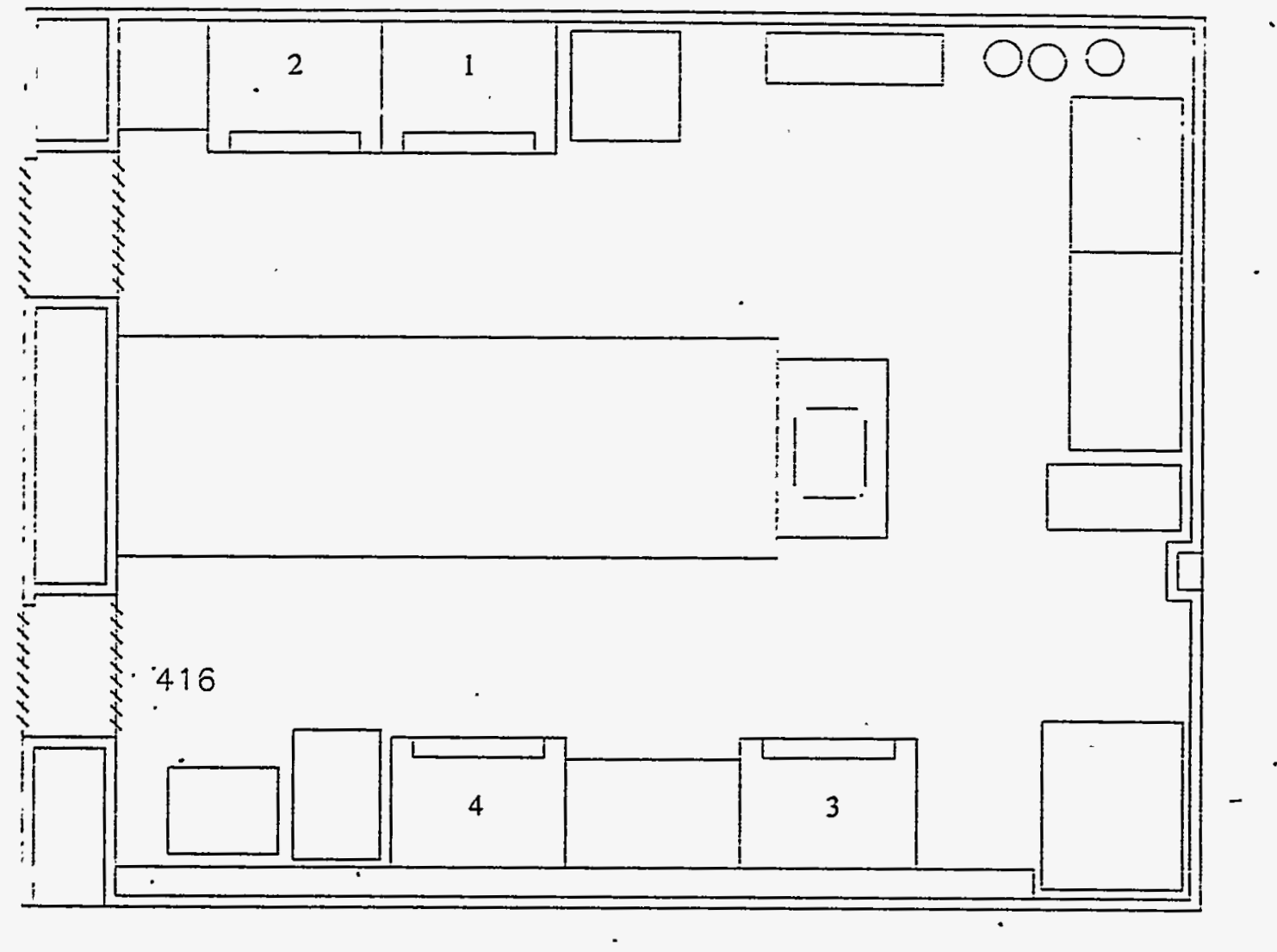

B. 13 


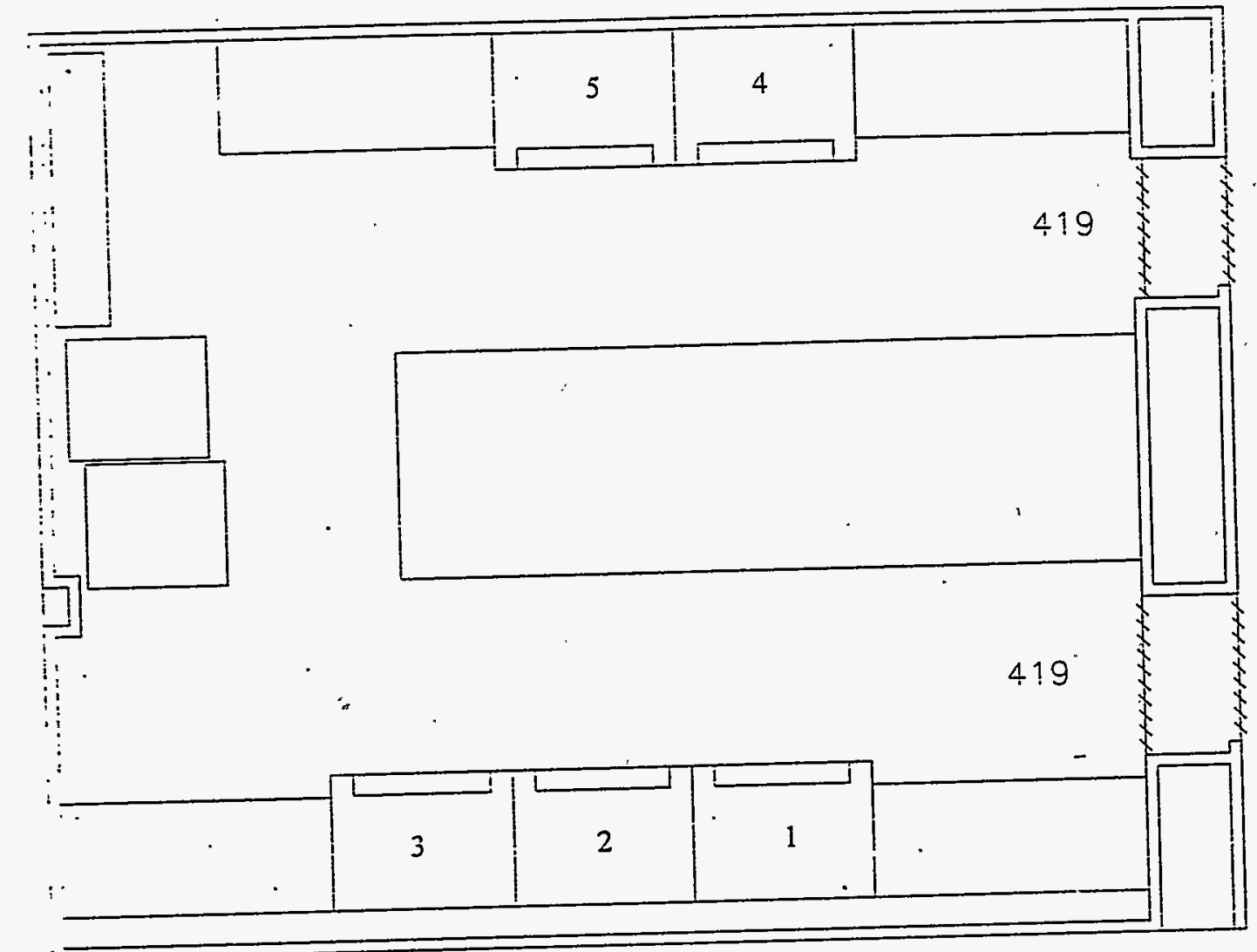

B. 14 


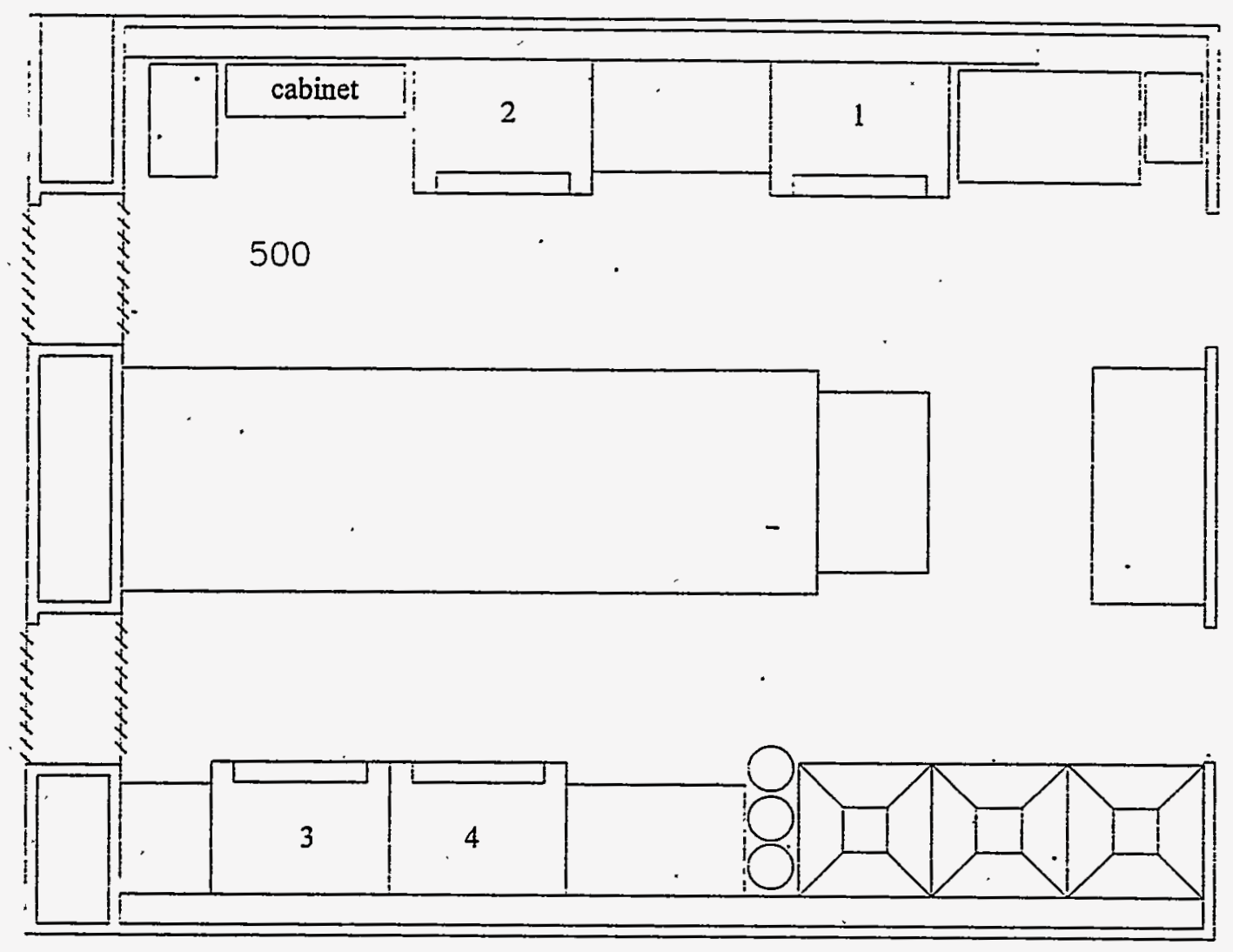

B. 15 


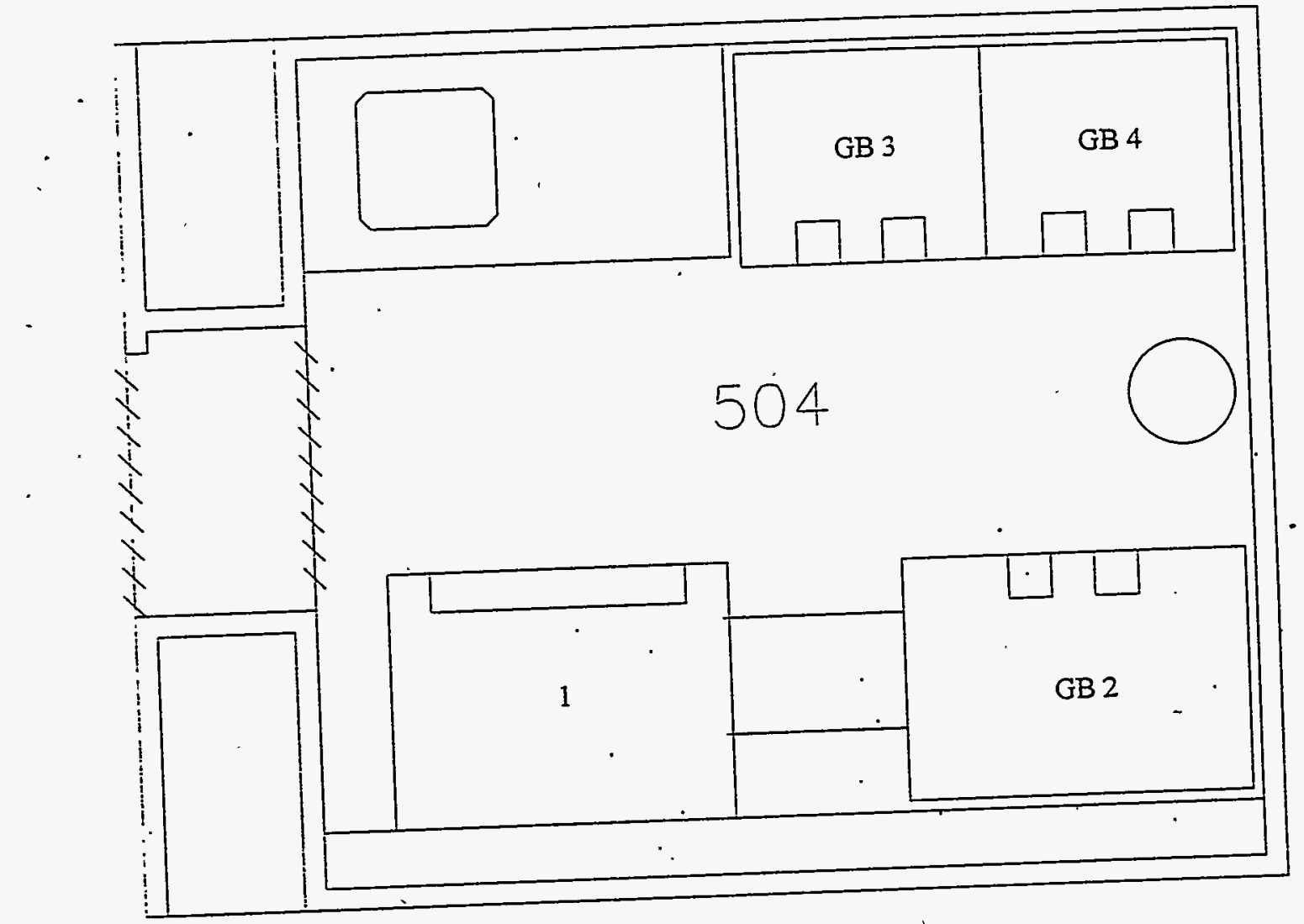

B. 16 


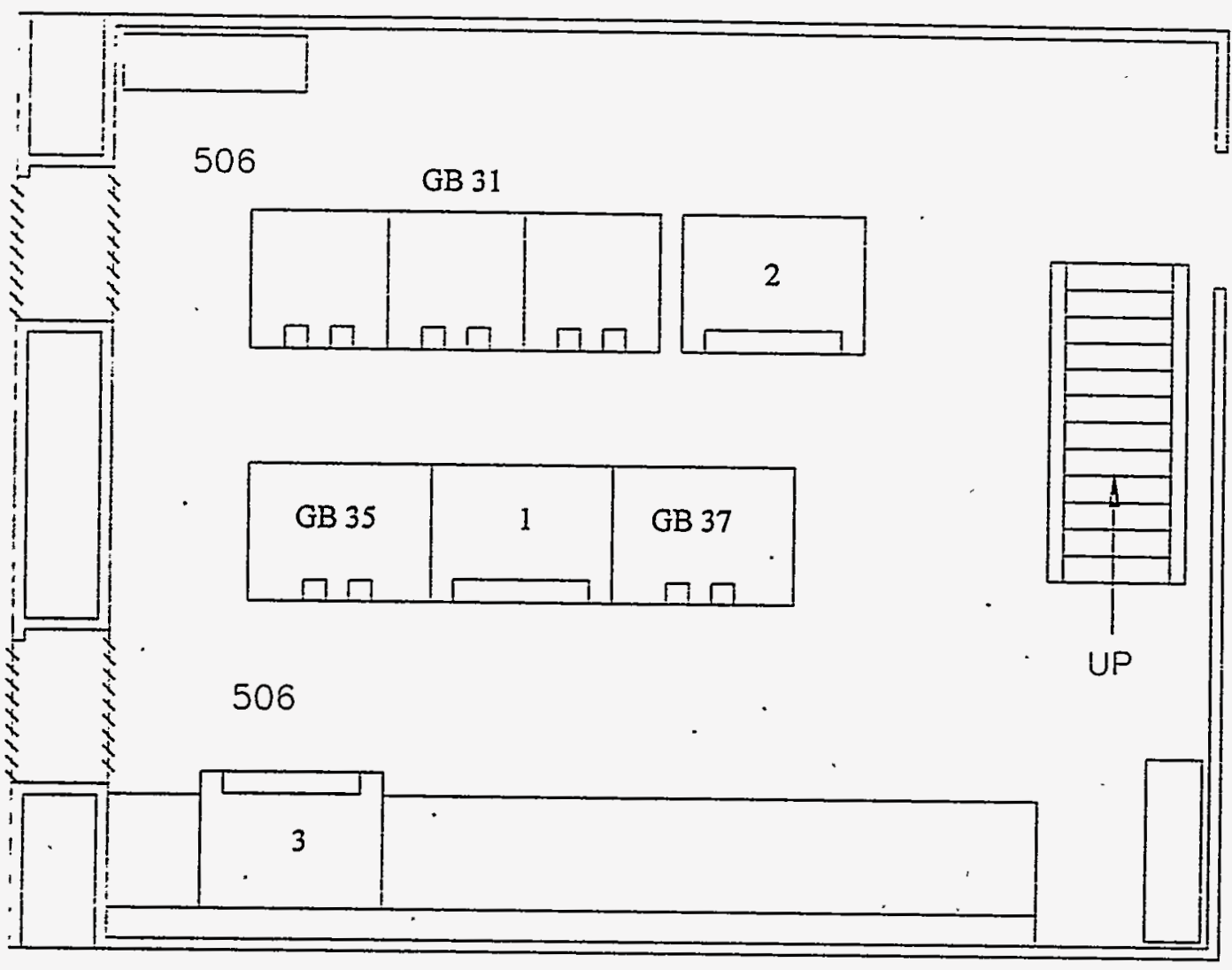

B. 17 


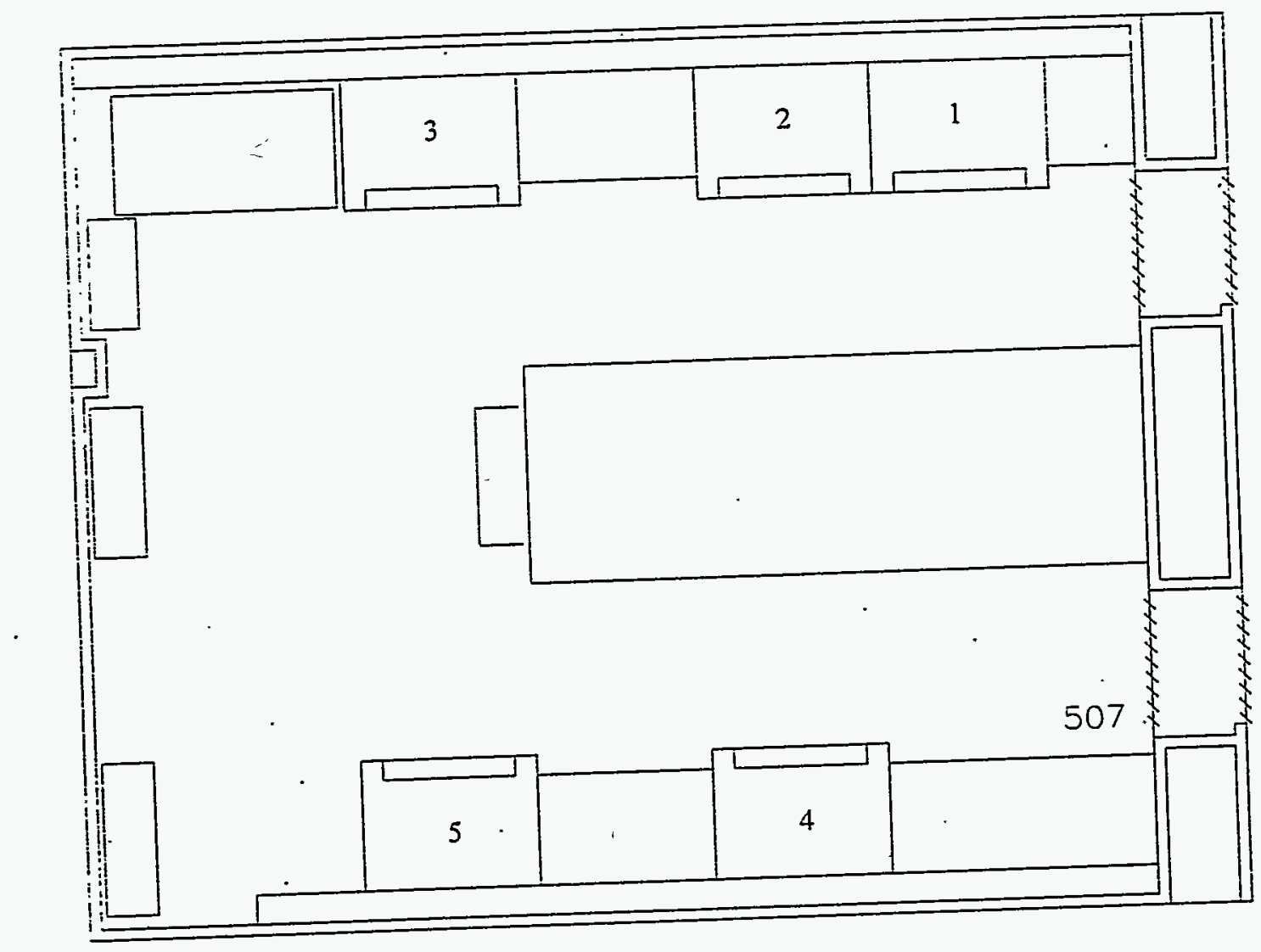

B. 18 
PNL Analytical Chemistry Laboratory

$10 / 11 / 95$

Radiochemistry Group, 325 Bldg.

Client: P. Gaither K41812 Analyst:

Reviewer:

Sample: Lab Vac Slab Tank ALO\# 96-00128

Small aliquots of the as received sample were mounted for total alpha, alpha energy analysis, total beta, and gamma energy analysis. Results appear to be reasonably consistent with previous analyses on this tank performed in March 1995. The alpha energy analysis (AEA) clearly indicates the presence of $239 \mathrm{Pu}$, although this technique cannot discriminate between 241 Am and 238Pu. However, the gamma energy analysis (GEA) confirms that the majority of the alpha activity is due to $241 \mathrm{Am}$.

- Activity ( $\mu \mathrm{Ci} / \mathrm{ml})$ - Reference Date: 10/11/95.

Total Alpha: $\quad 5.58 E-2 \pm 4 \%$

AEA: $241 \mathrm{Am} / 238 \mathrm{Pu} \quad 5.16 \mathrm{E}-2 \pm 6 \% \quad$ Note: GEA indicates mostly $241 \mathrm{Am}$

$239 \mathrm{Pu} \quad 4.24 \mathrm{E}-3 \pm 8 \%$

Total Beta : $\cdot \quad$ 1.13E-1 $\pm 4 \%$

GEA: $241 \mathrm{Am} \quad 4.52 E-2 \pm 3 \%$

137 Cs $\quad 5.17 E-3 \pm 3 \%$

154Eu $1.07 E-3+4 \%$

155EL $\quad 3.57 E-4 \pm 12 \%$

152Eu $\quad 5.35 E-4 \pm 8 \%$ 


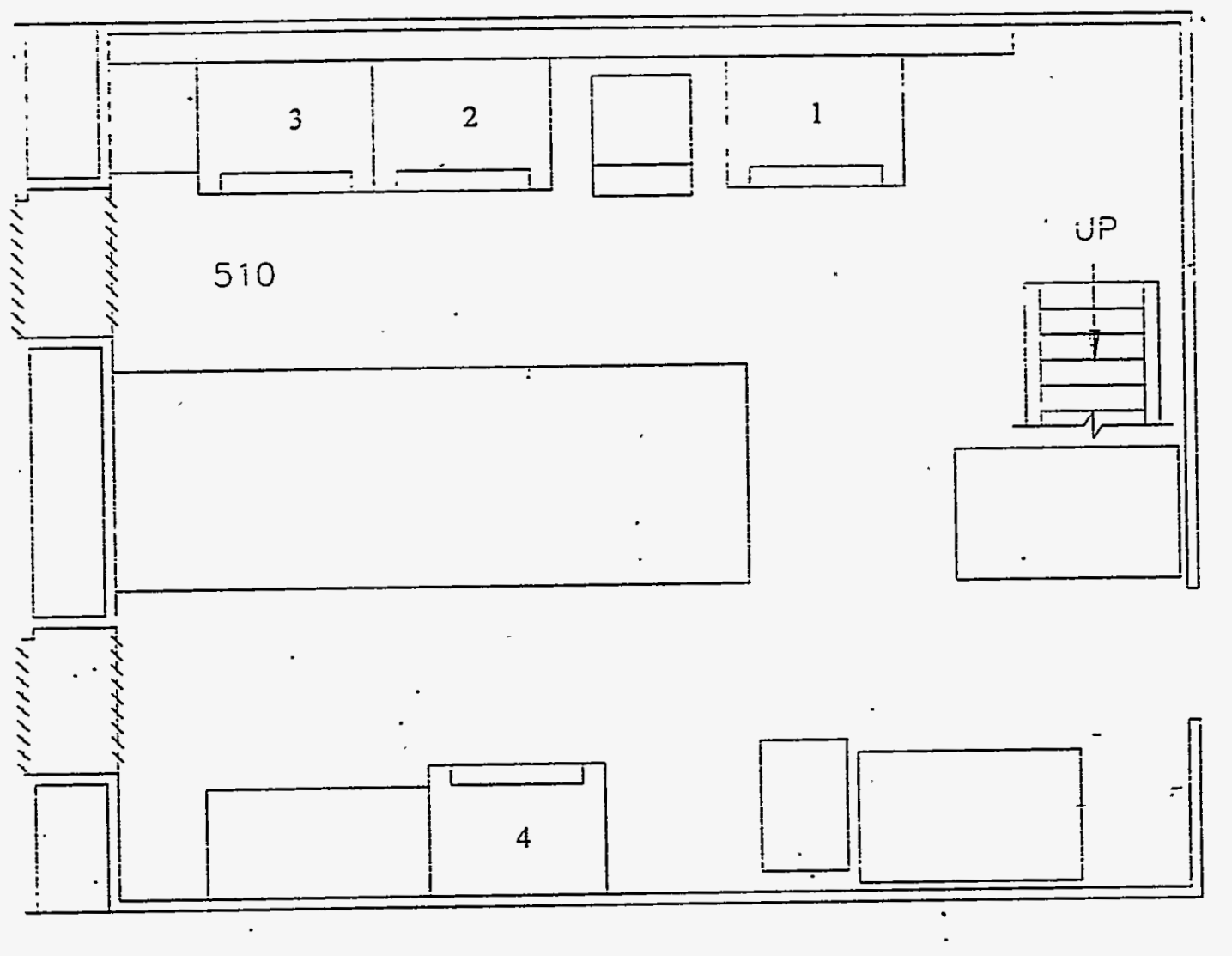

B. 20 


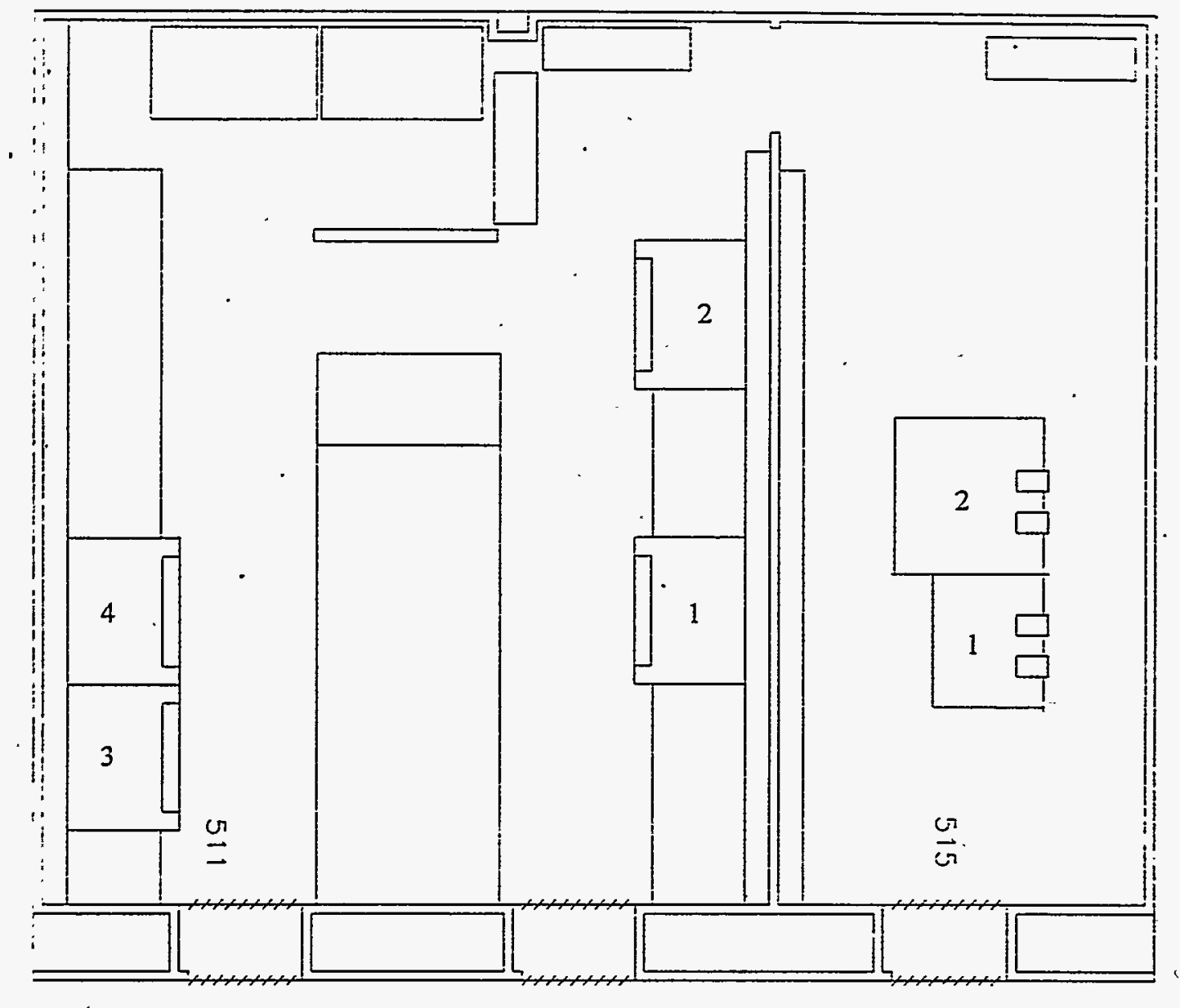

B. 21 


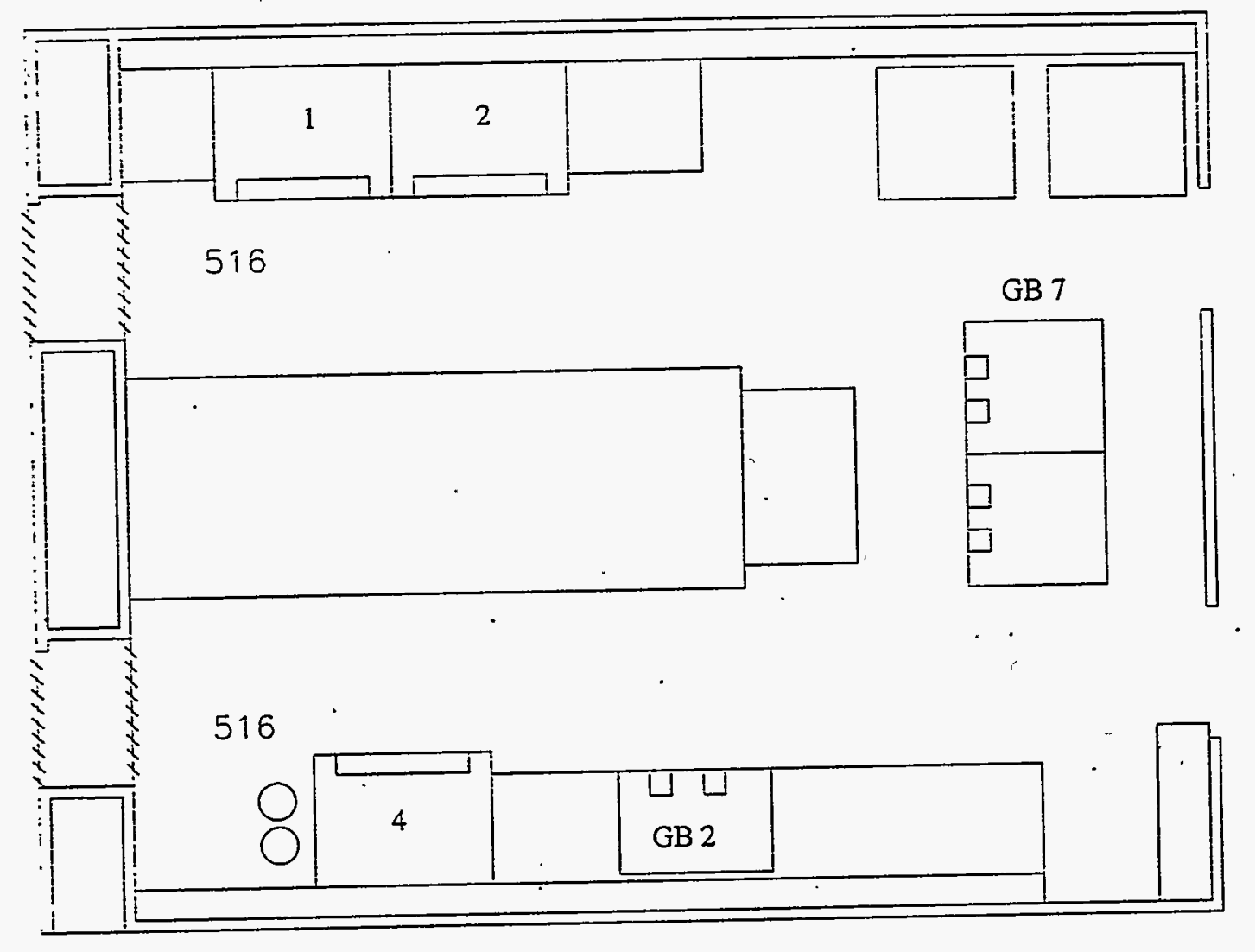




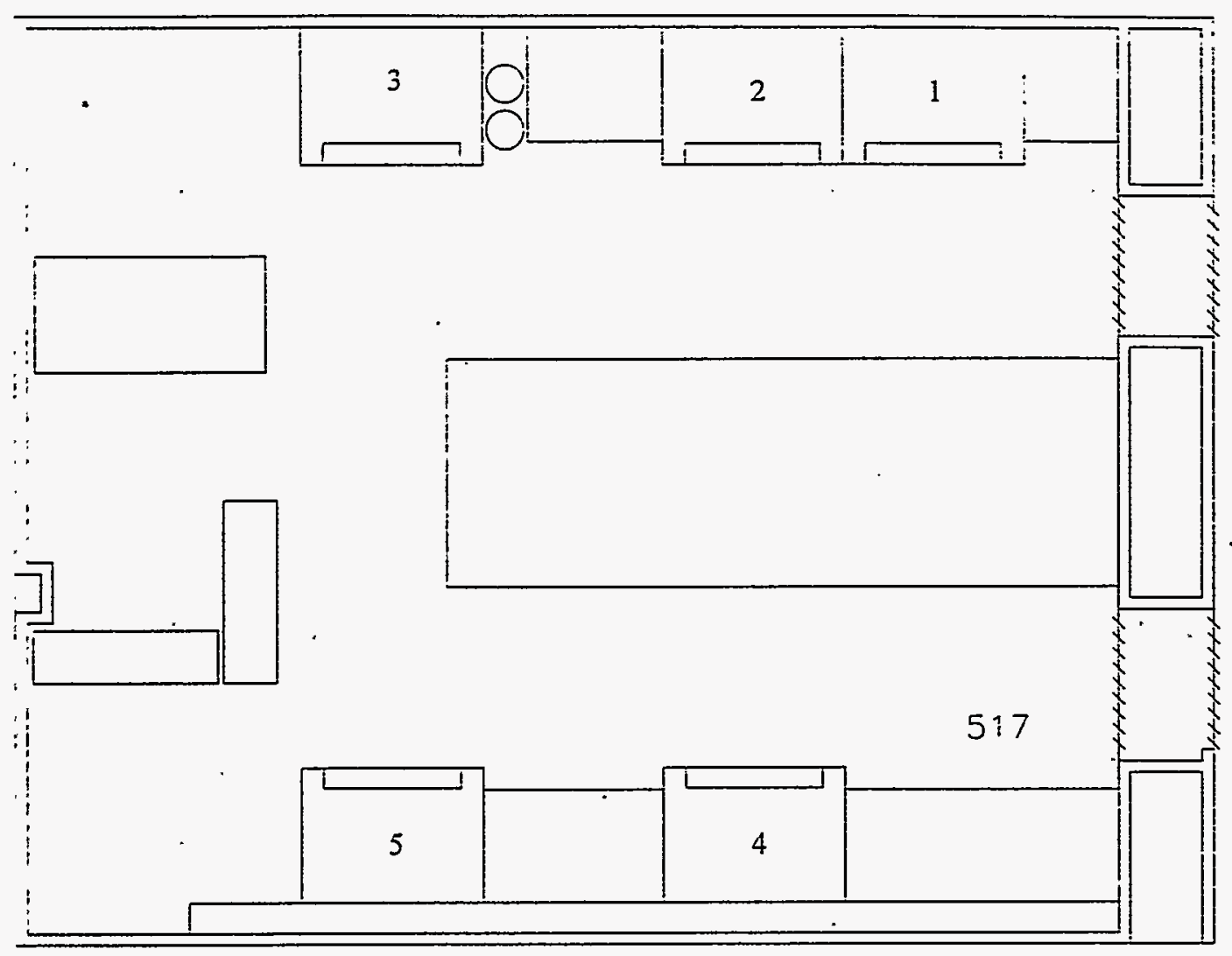

B. 23 


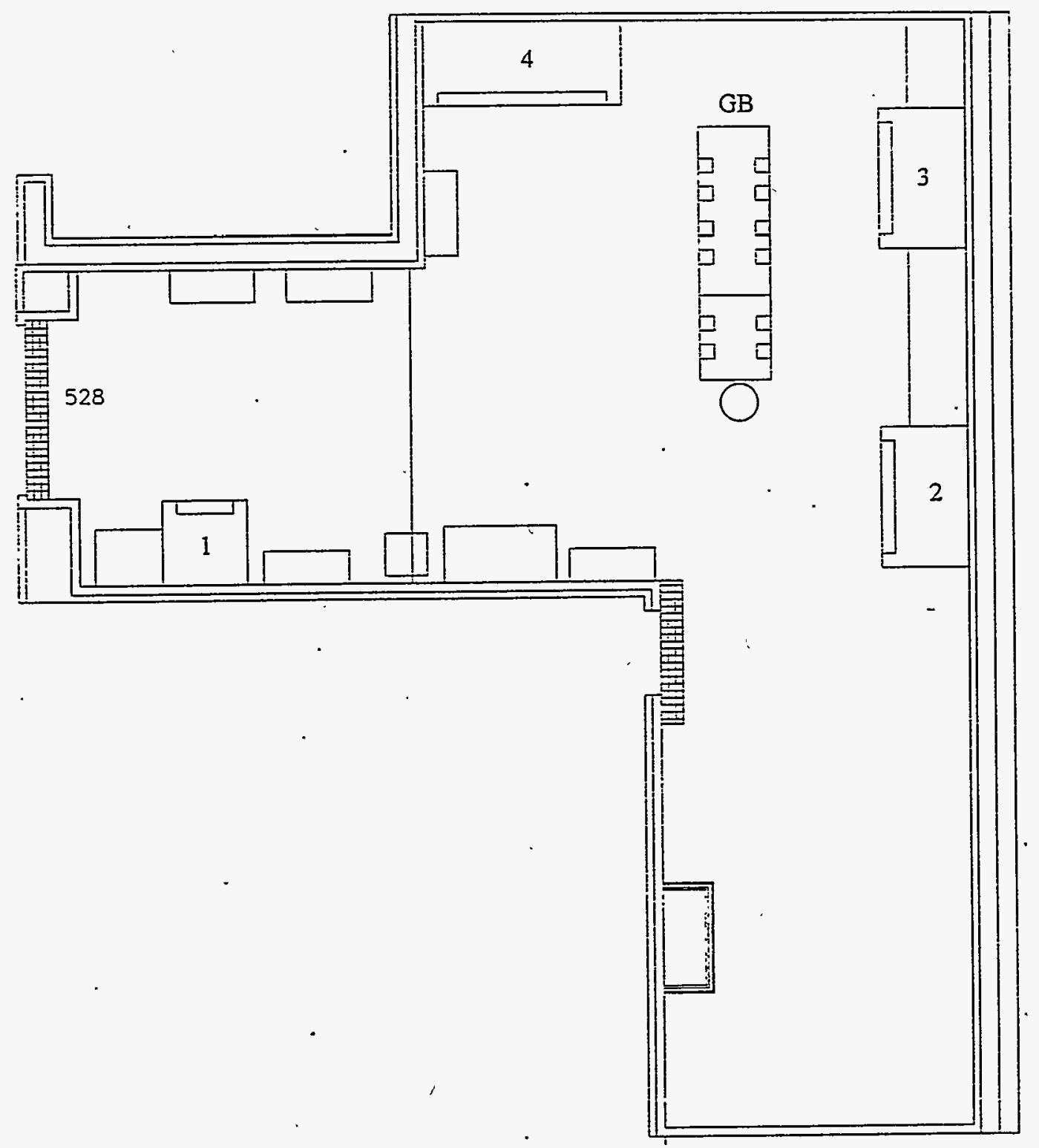




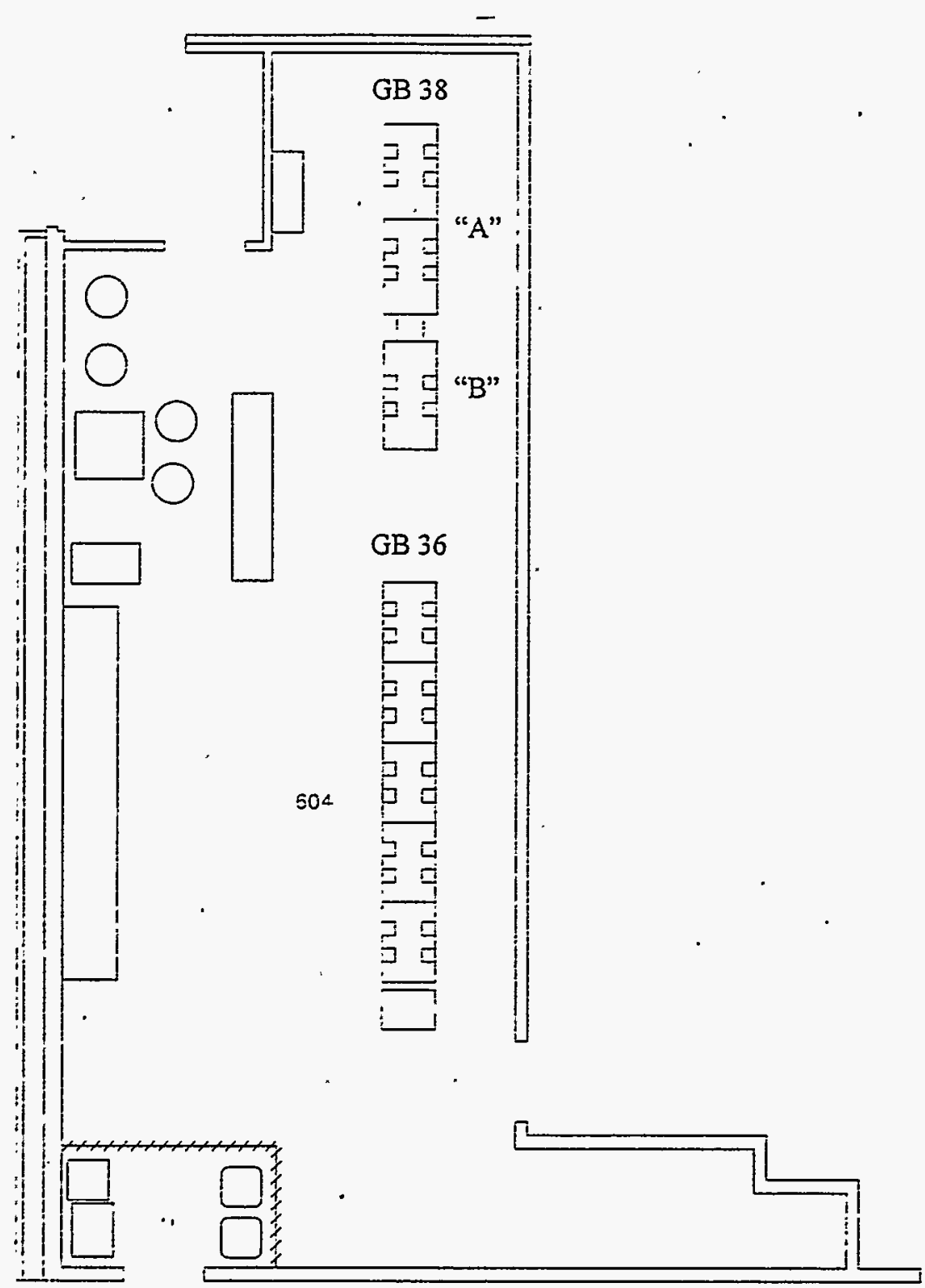




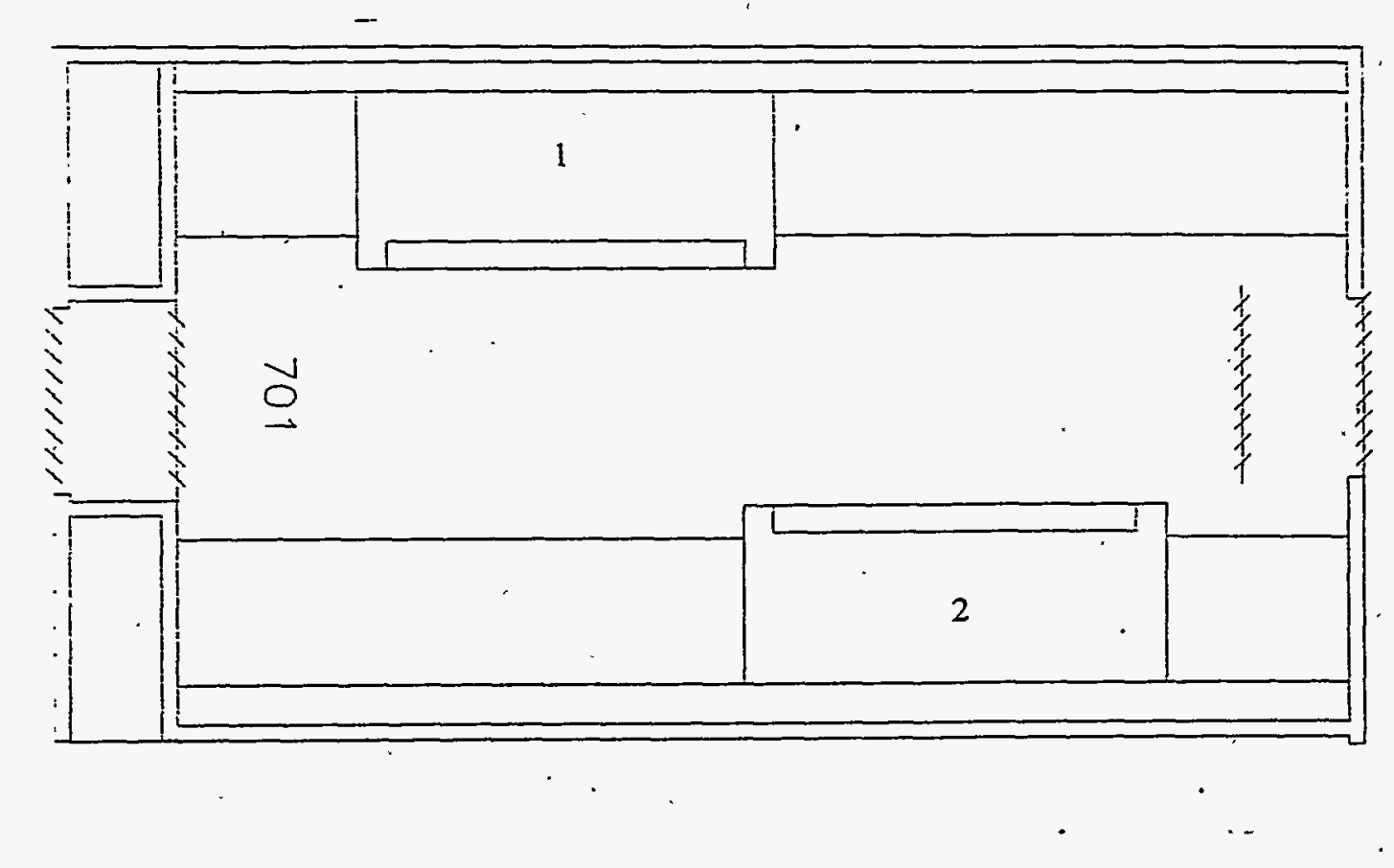

1 
Appendix C

Neutron Measurement Results 


\section{Appendix C}

\section{Neutron Measurement Results}

This appendix contains the spreadsheet analysis of the neutron counting data using the methods outlined in Section 3.5. Basically, the count rate is determined, then corrected for neutron background using the method explained in Section 3.5.2. Then, a correction is made to compensate for room scatter and distance from the source, using Equation 4.6. Finally, the background-corrected count rate is divided by the counts/second/gram of plutonium to derive the mass of plutonium. (based on weapons grade isotopics).

C.1 


\begin{tabular}{|c|c|c|c|c|c|c|c|c|c|c|c|c|c|c|}
\hline \multirow[b]{2}{*}{ ' } & \multicolumn{14}{|c|}{325 NEUTRON MEASUREMENTS } \\
\hline & & $\begin{array}{l}\text { NDA Log } \\
\text { Number }\end{array}$ & Location & $\begin{array}{l}\text { Detector } \\
\text { Height, in }\end{array}$ & $\begin{array}{l}\text { Detector } \\
\text { to Source } \\
\text { Distance }\end{array}$ & ROI Start & ROI Stop & $\begin{array}{l}\text { Integral } \\
\text { Counts }\end{array}$ & $\begin{array}{l}\text { Count } \\
\text { Time }\end{array}$ & $\begin{array}{l}\text { Count } \\
\text { Rale }\end{array}$ & $\begin{array}{l}\text { Bkgrnd } \\
\text { Corrected }\end{array}$ & $\begin{array}{c}\text { towards/ } \\
\text { away }\end{array}$ & $\begin{array}{c}\text { grams of } \\
\mathrm{Pu}\end{array}$ & Filename \\
\hline \multirow{30}{*}{ N } & & $2 / 2 / 96$ & & &. & & & & & & & & & \\
\hline & s & & $\mathrm{rm} 43 \mathrm{drm}$ & $16.5^{\prime \prime}$ & 12 & 87 & 2046 & 33,478 & 300 & 111.59 & & . & . & \\
\hline & $\mathbf{s}^{\circ}$ & . & $"$ & 16.5 & 12 & 87 & 2046 & 32,148 & 300 & 107.16 & & & & \\
\hline & s & & $"$ & 16.5 & 12 & 87 & 2046 & 33,091 & 300 & 110.30 & & & & \\
\hline & $\mathbf{s}$ & & $"$ & 16.5 & 12 & 87 & 2046 & 33,431 & 300 & 111.44 & & & & \\
\hline & s & & $"$ & 16.5 & 12 & 87 & 2046 & 33,235 & 300 & 110.78 & & & & \\
\hline & $b$ & & $\mathrm{rm} 43$ & 16.5 & 24 & 87 & 2046 & $8,602,566$ & 100,000 & 86.03 & . & & & long_ct \\
\hline & & $2 / 8 / 96$ & & & & & & & & & & , & & \\
\hline & $\mathbf{s}$ & & $\mathrm{rm} 42 \mathrm{dr}$ & 16.5 & 12 & 87 & 2046 & 740,409 & 300 & 2468.03 & & & & \\
\hline & $s$ & & $\mathrm{rm} 42 \mathrm{dr}$ & 16.5 & 12 & 87 & 2046 & 741,461 & 300 & 2471.54 & & & & \\
\hline & $\mathbf{s}$ & & $\mathrm{rm} 42 \mathrm{dr}$ & 16.5 & 12 & 87 & 2046 & 717,369 & 300 & 2391.23 & & & & \\
\hline & & $2 / 8 / 96$ & & & & & & & & $\cdot$ & & & & \\
\hline & $t$ & . & $45-$ & 67 & 24 & 87 & 2046 & 18,836 & 300 & 62.79 & 61.77 & 25.92 & 4.03 & h506h3t \\
\hline & $\mathbf{a}$ & & $45-$ & 67 & 24 & 87 & 2046 & 25,705 & 300 & 85.68 & 84.67 & & & h506h3a \\
\hline & $\mathbf{a}$ & & $45-$ & 67 & 24 & 87 & 2046 & 29,876 & 300 & 99.59 & 98.57 & & & h506h1a \\
\hline & $t$ & & $45-$ & 67 & 24 & 87 & 2046 & 21,322 & 300 & 71.07 & 70.06 & 27.70 & 4.31 & h506h1t \\
\hline & $a$ & & $45-$ & 67 & 24 & 87 & 2046 & 34,116 & 300 & 113.72 & 112.70 & & & h504gb1a \\
\hline & $t$ & & $45-$ & 67 & 24 & 87 & 2046 & 25,515 & 300 & 85.05 & 84.03 & 36.91 & 5.74 & h504gb1t \\
\hline & $a$ & & $45-$ & 67 & 24 & 87 & 2046 & 32,975 & 300 & 109.92 & 108.90 & & & h506gb1a \\
\hline & $t$ & & $45-$ & 67 & 24 & 87 & 2046 & 24,206 & 300 & 80.69 . & 79.67 & 33.63 & 5.23 & h506gb1t \\
\hline & & $2 / 9 / 96$ & & & & & & & & & & & & \\
\hline & $\mathbf{s}$ & & $\mathrm{rm} 43$ & 18.5 & 12 & 87 & 2046 & 32,405 & 300 & 108.02 & 107.00 & & & \\
\hline & $t$ & & $45-$ & 64.5 & 24 & .87 & 2046 & 29,638 & 300 & 98.79 & 97.78 & 72.63 & 11.29 & h4basext \\
\hline & $a$ & & $45-$ & 64.5 & 24 & 87 & 2046 & 26,287 & 300 & 87.62 & 86.61 & & . & h4basexa \\
\hline & $t$ & & 45 & 64.5 & 24 & 87 & 2046 & 22,701 & 300 & 75.67 & 74.65 & 56.09 & 8.72 & h511h3t \\
\hline & $a$ & & 45 & 64.5 & 24 & 87 & 2046 & 19,855 & 300 & 66.18 & 65.17 & & & h511h3a \\
\hline & $t$ & & $45-$ & 64.5 & 24 & 87 & 2046 & 17,098 & 300 & 56.99 & 55.98 & 41.64 & 6.47 & h511h4t \\
\hline & $a$ & & $45-$ & 64.5 & 24 & 87 & 2046 & 15,152 & 300 & 50.51 & 49.49 & & & h511h4a \\
\hline & & $2 / 14 / 96$ & & & & & & & & & & & & . \\
\hline & $s$ & & $\mathrm{rm} 42$ & 18.5 & 12 & 87 & .2046 & 525,332 & 300 & 1751.11 & 1750.33 & & & \\
\hline
\end{tabular}




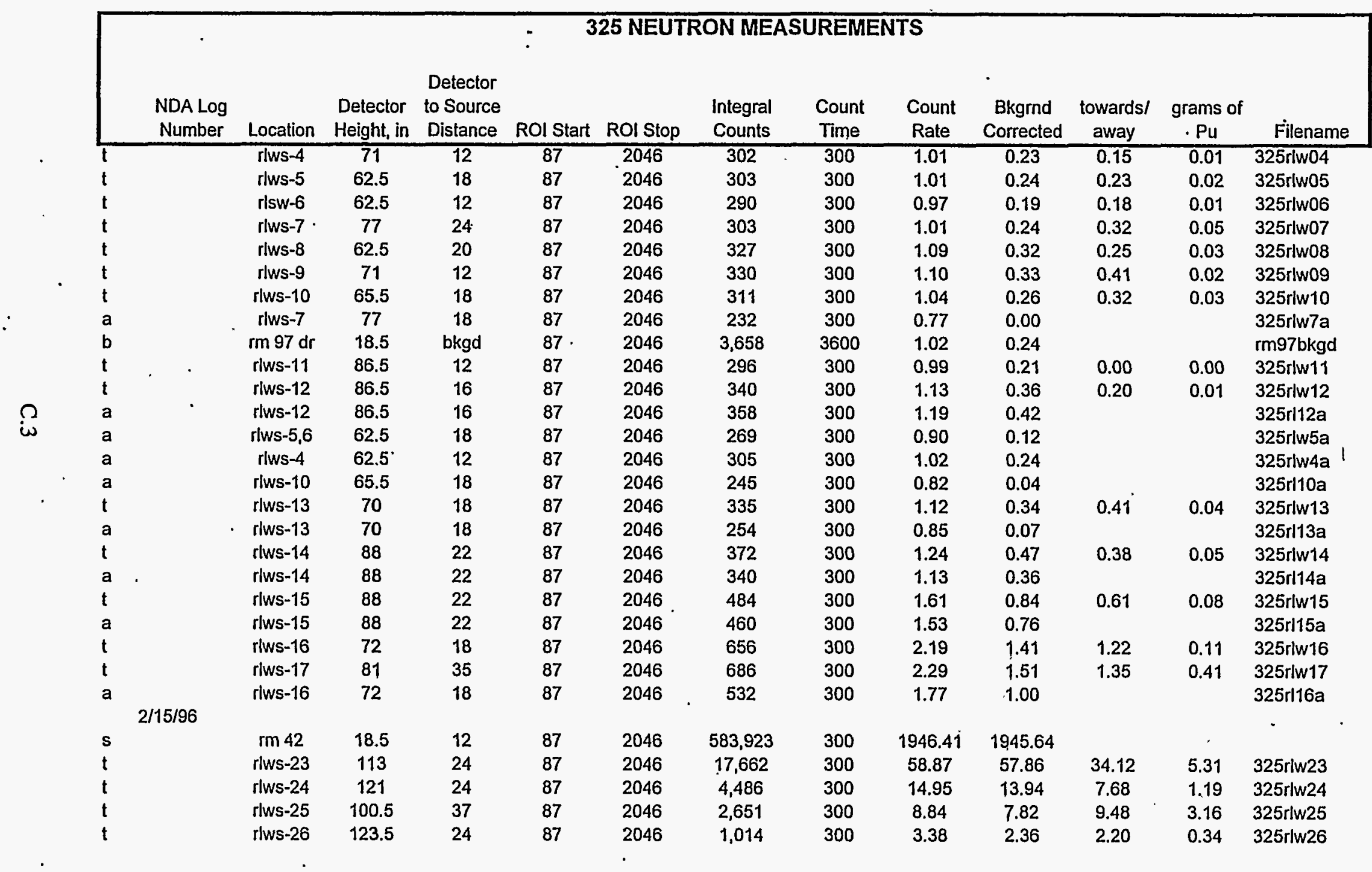




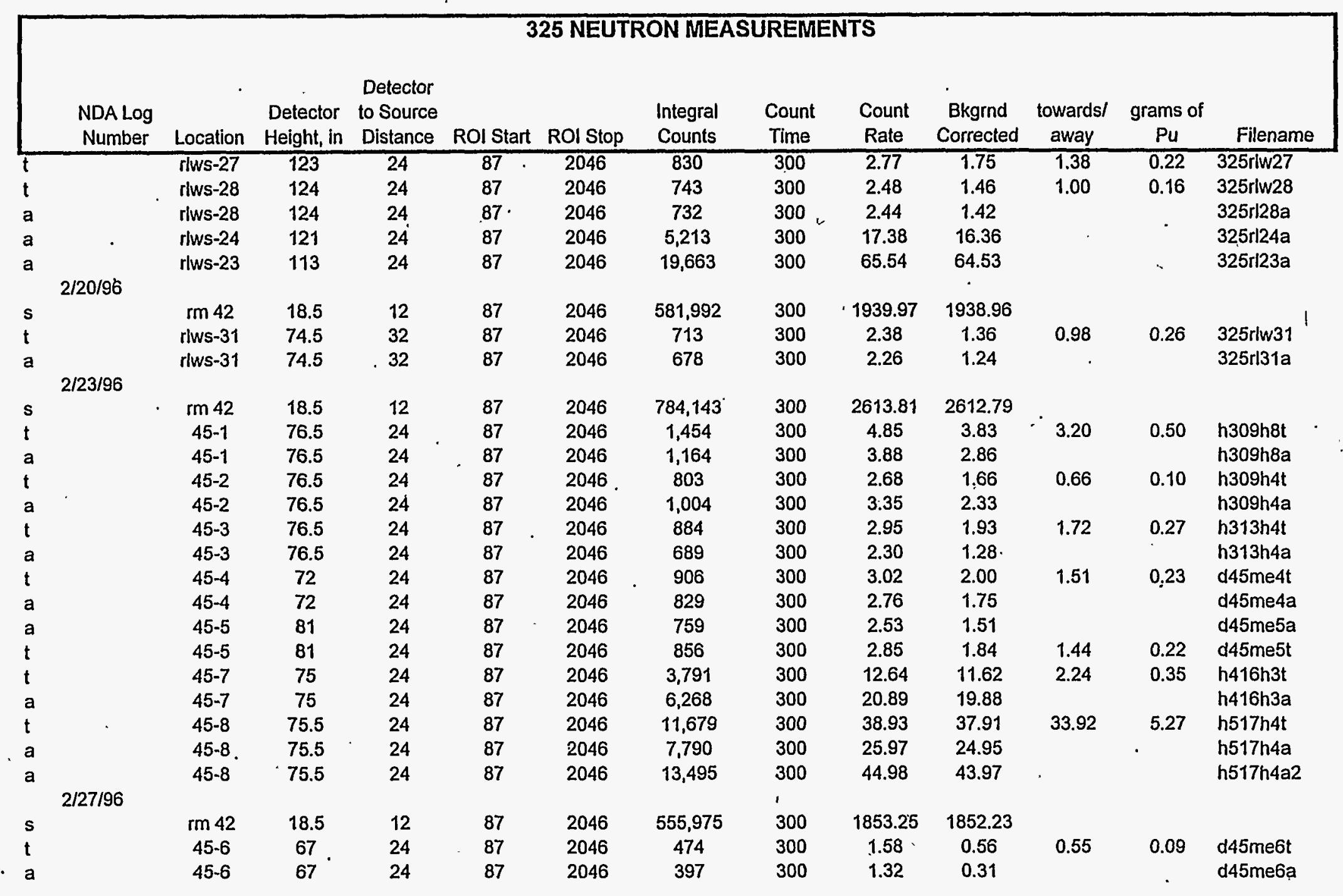




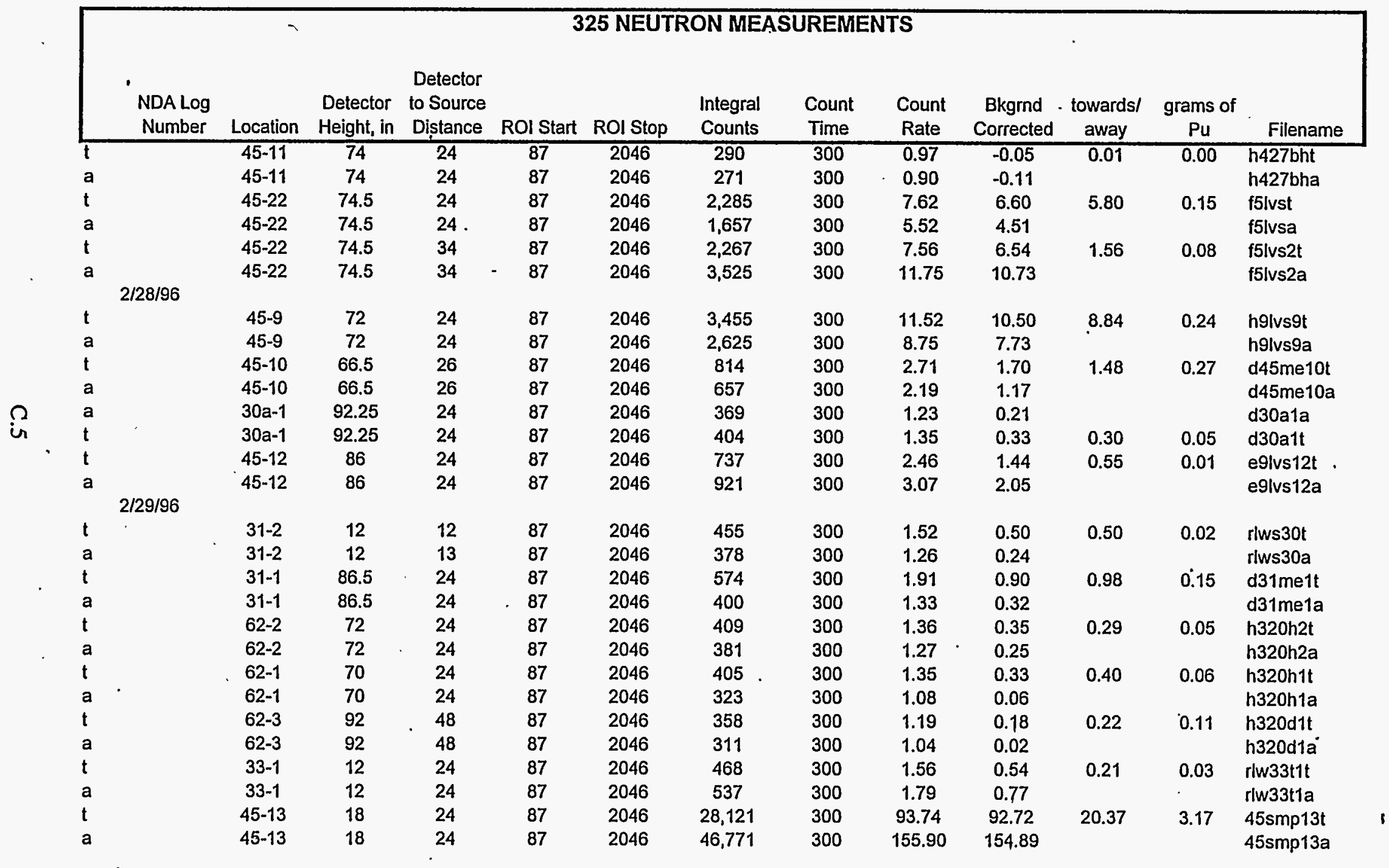




\section{NEUTRON MEASUREMENTS}

Detector

NDA Log Detector to Source

Number Location Height, in Distance ROI Start ROI Stop

Integral Count Count B Bkgrnd towards/ grams of Time

Rate Corrected away

$\mathrm{Pu}$

Filename

a

(

$t$

t

a

a

$? \quad a$

o

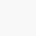

$3 / 6 / 96$

\begin{tabular}{ccc}
$45-14$ & 25 & 24 \\
$45-14$ & 25 & 24 \\
$45-15$ & 90 & 24 \\
$45-15$ & 96 & 18 \\
$45-16$ & 80 & 32 \\
$45-17$ & 85 & 24 \\
$45-18$ & 84 & 25 \\
$45-18$ & 82 & 27 \\
$45-17$ & 85 & 24 \\
$45-16$ & 78 & 26 \\
$45-15$ & 90 & 24 \\
$45-15$ & 96 & 18 \\
& & \\
rm 42 & 18.5 & 12 \\
$45-19$ & 85 & 24 \\
$45-19$ & 85 & 24 \\
$45-20$ & 93 & 40 \\
$45-20$ & 93 & 40 \\
$45-21$ & 93 & 40 \\
$45-21$ & 93 & 40 \\
$45-23$ & 86 & 27 \\
$45-23$ & 86 & 27 \\
\hline & & \\
rm 42 & 18.5 & 12 \\
lab 313 & 38.5 & 30 \\
lab 313 & 50.5 & 30 \\
lab 313 & 50.5 & 30 \\
lab 313 & 50.5 & 30 \\
lab 313 & 50.5 & .30
\end{tabular}

\begin{tabular}{ll}
87 & 2046 \\
87 & 2046 \\
87 & 2046 \\
87 & 2046 \\
87 & 2046 \\
87 & 2046 \\
87 & 2046 \\
87 & 2046 \\
87 & 2046 \\
87 & 2046 \\
87 & 2046 \\
87 & 2048 \\
& \\
87 & 2046 \\
87 & 2046 \\
87 & 2046 \\
87 & 2046 \\
87 & 2046 \\
87 & 2046 \\
87 & 2046 \\
87 & 2046 \\
87 & 2046 \\
- & \\
87 & 2046 \\
87 & 2046 \\
87 & 2046 \\
87 & 2046 \\
87 & 2046 \\
87 & 2046 \\
\hline
\end{tabular}

\begin{tabular}{l}
462 \\
$571 . \quad 300$ \\
\hline
\end{tabular}

$\begin{array}{cc}571 & 300 \\ 14,303 & 300\end{array}$

14,608

$28,729 \quad 300$

$27,594 \quad 300$

$5,954 \quad 300$

$4,871 \quad 300$

$29,027 \quad 300$

$30,533 \quad 300$

$\begin{array}{ll}11,397 & 300 \\ 11,323 & 300\end{array}$

300

673,912

2,114

$1,821 \quad 300$

1,821
603

764

659

659
509

718

718
697

745,346

745,346
640

848

686

686
977

1,142

1.54
1.90
47.68
48.69
95.76

$\begin{array}{lll}0.52 & .0 .11 \quad 0.00\end{array}$

45Ivs14t

45Ivs14a

$\begin{array}{llll}0.89 & & & 45 \mathrm{lvs} 14 \mathrm{a} \\ 46.66 & 37.56 & 1.00 & 45 \mathrm{lvs} 15 \mathrm{t}\end{array}$

$\begin{array}{llll}47.68 & 39.08 & 0.61 \quad 45 \mathrm{lvs} 15 \mathrm{u}\end{array}$

$\begin{array}{lllll}19.85 & 18.83 & 14.96 & 0.43 & 45 \text { lvs } 18 t\end{array}$

$16.24 \quad 15.22 \quad 45 \mathrm{Ivs} 18 \mathrm{a}$

$96.76 \quad 95.74 \quad 45 \mathrm{lvs} 17 \mathrm{a}$

$101.78 \quad 100.76 \quad 45 \mathrm{lvs} 16 \mathrm{a}$

$\begin{array}{lll}37.99 & 36.97 \quad \text {. } \quad 45 \mathrm{lvs} 15 \mathrm{a}\end{array}$

$37.74 \quad 36.73 \quad 45$ Ivs15b

$2246.37 \quad 2245.36$.

$\begin{array}{lllll}7.05 & 6.03 & 4.67 & 0.12 & 45 \text { Ivs19t }\end{array}$

$6.07 \quad 5.05$

$2.01 \quad 0.99$

$2.55 \quad 1.53$

2.20

1.70

1.18
0.68

$2.39-1.38$

2.32

1.31

$2484.49 \quad 2483.47$

$\begin{array}{ll}2.13 & 0.74 \\ 2.83 & 1.44\end{array}$

$2.29^{\circ}-0.90$

$\begin{array}{ll}3.26 & 1.87\end{array}$

$3.81 \quad 2.42$

45lvs19a

$45 \mathrm{lvs} 20 \mathrm{a}$

$1.38 \quad \cdot 0.09 \quad 45 \mathrm{Ivs} 20 \mathrm{t}$

$\begin{array}{lll}1,12 & 0.07 \quad 45 \text { Ivs21t }\end{array}$

45lvs2it

45 Ivs 23

$0.82 \quad 0.03 \quad 45$ lvs23t

$0.03 \quad 0.01 \quad 313 \mathrm{~h} 1 \mathrm{t}$

$0.05 \quad 313 \mathrm{~h} 1 \mathrm{a}$

$313 \mathrm{~h} 2 \mathrm{a}$ 


\section{NEUTRON MEASUREMENTS}

Detector

NDA Log Detector to Source * Integral Count :Count Bkgrnd towards/ grams of

Number Location Height, in Distance ROIStart ROIStop Counts Time Rate Corrected away Pu Filename

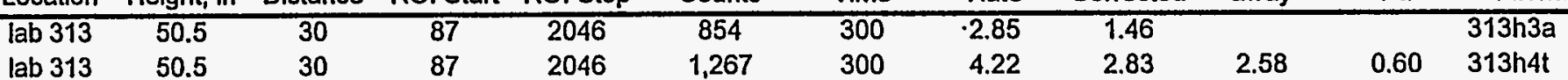

lab $313 \quad 50.5 \quad 30 \quad 37 \quad 2046 \quad 1,267$

$\begin{array}{llllllllll}\text { lab } 313 & 50.5 & 30 & 87 & 2046 & 956 & 300 & 3.19 & 1.80 & 313 \mathrm{~h} 4 \mathrm{a}\end{array}$

$\begin{array}{llllllllllll}\text { lab } 309 & 50.5 & 30 & 87 & 2046 & 1,279 & 300 & 4.26 & 2.87 & 0.90 & 0.21 & 309 \mathrm{~h} 1 \mathrm{t} .\end{array}$

$\begin{array}{llllllllll}\text { lab } 309 & 50.5 & 30 & 87 & 2046 & 1,736 & 300 & 5.79 & 4.40 & 309 \mathrm{~h} 1 \mathrm{a}\end{array}$

$\begin{array}{llllllllllll}\text { lab } 309 & 50.5 & 30 & 87 & 2046 & 1,395 & 300 & 4.65 & 3.26 & 0.78 & 0.18 & 309 \mathrm{~h} 2 \mathrm{t}\end{array}$

lab $309-50.5 \quad 30-87-30-2046$

lab $309 \quad 50.5$

lab $309 \quad 50.5$

lab $309 \quad 50.5$

lab $309 \quad 50.5$

lab $309 \quad 50.5$

lab $309 \quad 50.5$

lab $309 \quad 50.5$

lab $309 \quad 50.5$

lab $309 \quad 50.5$

lab $309 \quad 50.5$

lab $309 \quad 50.5$

$\mathrm{lab} 309 \quad 50.5$

2046

2,021

$300 \quad 6.74 \quad 5.35$

$\begin{array}{lllll} & 2046 & 1,910 & 300 & \end{array}$

$\begin{array}{llllll}87 & 2046 & 2,784 & 300 & 9.28 & 7.89\end{array}$

$\begin{array}{llllll}87 & 2046 & 2,158 & 300 & 7.19 & 5.80\end{array}$

2046

3,033

5.80
8.72

$12.00 \quad 10.61$

$7.35 \quad 5.96$

$19.25 \quad 17.86$

$10.25 \quad 8.86$

$22.30 \cdot 20.91$

$11.63 \quad 10.24$

$\begin{array}{lllllll}4,625 & 300 & 15.42 & 14.03 & 12.88 & 3.72 & 309 h 8 t \\ 3,037 & 300 & 10.12 & 8.73 & & & 309 h 8 \mathrm{a}\end{array}$

$\begin{array}{lllllll}4,625 & 300 & 15.42 & 14.03 & 12.88 & 3.72 & 309 \mathrm{~h} 8 \mathrm{t} \\ 3,037 & 300 & 10.12 & 8.73 & & & 309 \mathrm{~h} 8 \mathrm{a}\end{array}$

$309 \mathrm{~h} 3 \mathrm{a}$
30.32

$1.92 \quad 0.45 \quad 309 h 4 t$

$\begin{array}{lll}10.18 & 2.37 \quad 309 h 4 a\end{array}$

$\begin{array}{lll}17.90 & 4.16 & 309 \mathrm{~h} 5 \mathrm{a} \\ 309 \mathrm{~h} 6 \mathrm{t}\end{array}$

$309 \mathrm{~h} 6 \mathrm{a}$

$21.06 \quad 4.90 \quad 309 \mathrm{htt}$

$\begin{array}{lllllll}3,489 & 300 & 11.63 & 10.24 & & & 309 \mathrm{~h} 7 \mathrm{a} \\ 4,625 & 300 & 15.42 & 14.03 & 12.88 & 3.72 & 309 \mathrm{~h} 8 \mathrm{t} \\ 3,037 & 300 & 10.12 & 8.73 & & & 309 \mathrm{~h} 8 \mathrm{a}\end{array}$

$3 / 8 / 96$

lab $303 \quad 50.5 \quad 30 \quad 30 \quad 87 \quad 2046$

1,292

$\begin{array}{lll}300 & 4.31 \quad .92\end{array}$

lab 303

$\begin{array}{llll}50.5 & 30 & 87 & 2046\end{array}$

1,292
2,151

$7.17 \quad 5.78$

$0.04 \quad 0.01 \quad 303 h 4 t$

$4.34 \quad 2.95$

$\begin{array}{lllll}\text { lab } 303 & 50.5 & 29.5 & \cdot 87 & 2046\end{array}$

2,132

300

7.11

5.72

$0.13 \quad 0.03 \quad 303+3 t$

$3 / 11 / 96$

$\begin{array}{lllllll}\text { lab 303 } & 50.5 & 30 & 87 & 2046 & 1,100 & 300 \\ \text { lab 303 } & 50.5 & .30 & 87 & 2046 & 1,890 & 300 \\ \text { lab 312 } & 50.5 & 30 & 87 & 2046 & 677 & 300 \\ \text { lab 312 } & 50.5 & 30 & 87 & 2046 & 615 & 300 \\ \text { lab 312 } & 50.5 & 30 & 87 & 2046 & 633 & 300\end{array}$

$\begin{array}{ll}3.67 & 2.28 \\ 6.30 & 4.91 \\ 2.26 & 0.87 \\ 2.05 & 0.66 \\ 2.11 & 0.72\end{array}$

$\begin{array}{lll}-0.24 & -0.06 \quad 303 h 1 t\end{array}$

303h1a

$0.50 \quad 0.12 \quad 312 \mathrm{hla}$ 


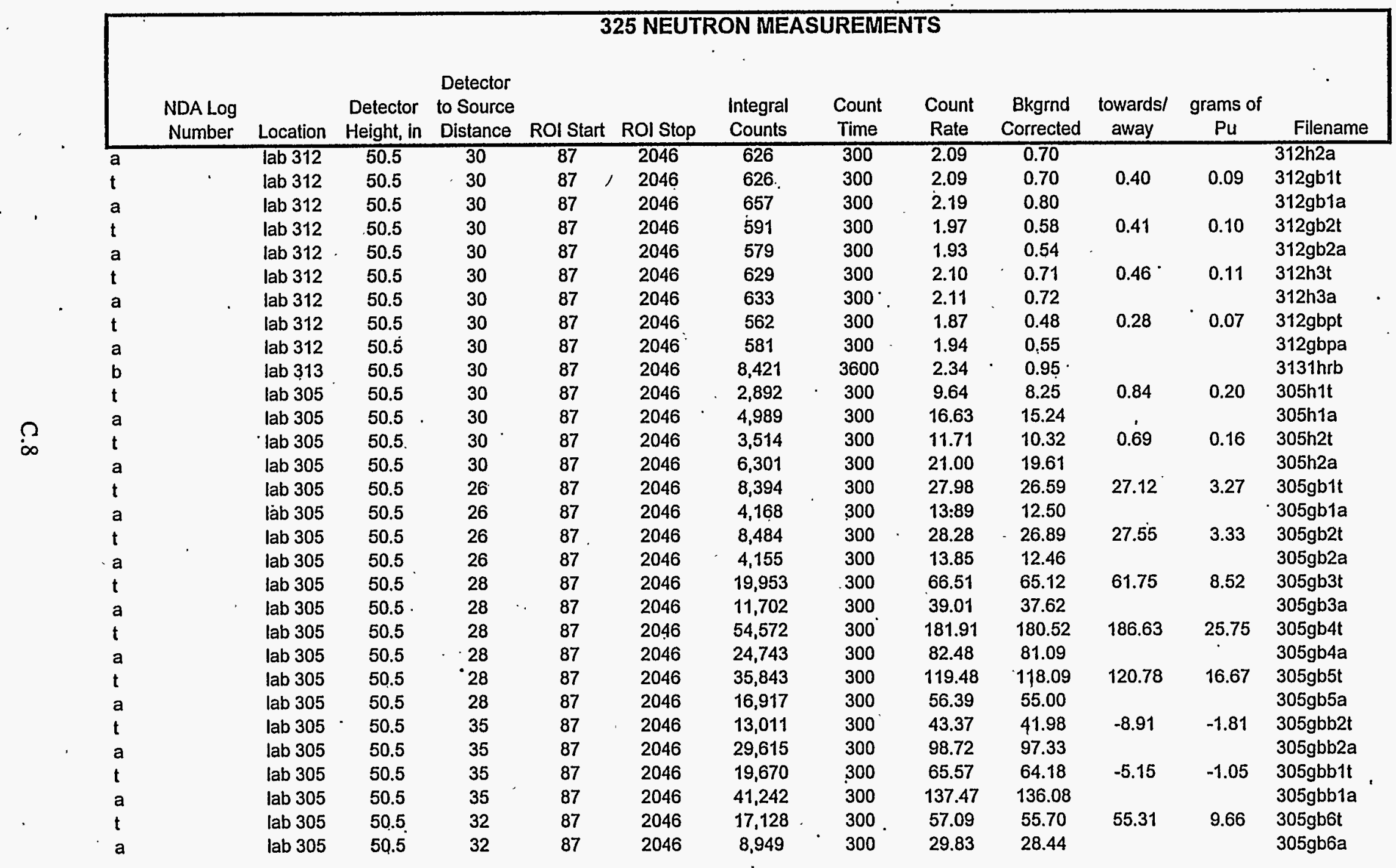




\begin{tabular}{|c|c|c|c|c|c|c|c|c|c|c|c|c|c|}
\hline & \multirow[b]{2}{*}{$\begin{array}{l}\text { NDA Log } \\
\text { Number }\end{array}$} & \multicolumn{11}{|c|}{325 NEUTRON MEASUREMENTS } & \multirow[b]{2}{*}{ Filename } \\
\hline & & Location & $\begin{array}{l}\text { Detector } \\
\text { Height, in }\end{array}$ & $\begin{array}{l}\text { Detector } \\
\text { to Source } \\
\text { Distance }\end{array}$ & ROI Start & ROI Stop & $\begin{array}{l}\text { Integral } \\
\text { Counts }\end{array}$ & $\begin{array}{l}\text { Count } \\
\text { Time }\end{array}$ & $\begin{array}{l}\text { Count } \\
\text { Rate }\end{array}$ & $\begin{array}{l}\text { Bkgrnd } \\
\text { Corrected }\end{array}$ & $\begin{array}{c}\text { towards/ } \\
\text { away }\end{array}$ & $\begin{array}{c}\text { grams of } \\
\mathrm{Pu}\end{array}$ & \\
\hline$t$ & & lab 305 & 50.5 & 32 & 87 & 2046 & 8,382 & 300 & 27.94 & 26.55 & 25.16 & 0.26 & 305gb7t \\
\hline a & $3 / 12 / 96$ & lab 305 & 50.5 & 32 & 87 & 2046 & 5,025 & 300 & 16.75 & 15.36 & & & $305 \mathrm{gb} 7 \mathrm{a}$ \\
\hline $\mathbf{t}$ & & lab 317 & 50.5 & 28 & 87 & 2046 & 521 & 300 & 1.74 & 0.35 & -0.21 & -0.04 & $317 \mathrm{~h} 1 \mathrm{t}$ \\
\hline a & & lab 317 & 50.5 & 28 & 87 & 2046 & 719 & 300 & 2.40 & 1.01 & & & 317h1a \\
\hline$t$ & & lab 317 & 50.5 & 28 & 87 & 2046 & 584 & 300 & 1.95 & 0.56 & 0.18 & 0.04 & $317 \mathrm{~h} 2 \mathrm{t}$ \\
\hline a & & lab 317 & 50.5 & 35 & 87 & 2046 & 669 & 300 & 2.23 & 0.84 & & & $317 \mathrm{~h} 2 \mathrm{a}$ \\
\hline$t$ & & lab 410 & 50.5 & 35 & 87 & 2046 & 1,935 & 300 & 6.45 & 4.75 & 2.31 & 0.70 & $410 \mathrm{~h} 1 \mathrm{t}$ \\
\hline a & & lab 410 & 50.5 & 35 & 87 & 2046 & 2,319 & 300 & 7.73 & 6.03 & & & $410 \mathrm{~h} 1 \mathrm{a}$ \\
\hline$t$ & & lab 410 & 50.5 & 35 & 87 & 2046 & 1,562 & 300 & 5.21 & 3.50 & $1.88^{\prime}$ & 0.57 & $410 \mathrm{~h} 2 \mathrm{t}$ \\
\hline a & & $\operatorname{lab} 410$ & 50.5 & 32 & 87 & 2046 & 1,767 & 300 & 5.89 & 4.19 & & & $\dot{4} 10 \mathrm{~h} 2 \mathrm{a}$ \\
\hline$t$ & & lab 410 & 50.5 & 32 & 87 & 2046 & 1,385 & 300 & 4.62 & 2.91 & 1.73 & 0.45 & $410 \mathrm{~h} 3 \mathrm{t}$ \\
\hline a & & $\operatorname{lab} 410$ & 50.5 & 32 & 87 & 2046 & 1,479 & 300 & 4.93 & 3.23 & & & $410 \mathrm{~h} 3 \mathrm{a}$ \\
\hline$t$ & & lab 410 & 50.5 & 32 & 87 & 2046 & 1,674 & 300 & 5.58 & 3.88 & 2.92 & 0.76 & $410 h 4 t$ \\
\hline $\mathbf{a}$ & & lab 410 & 50.5 & 32 & 87 & 2046 & 1,523 & 300 & 5.08 & 3.37 & & & $410 \mathrm{~h} 4 \mathrm{a}$ \\
\hline$t$ & & lab 410 & 50.5 & 31 & 87 & 2046 & 1,857 & 300 & 6.19 & 4.49 & 3.36 & 0.83 & $410 \mathrm{~h} 5 \mathrm{t}$ \\
\hline a & & $\operatorname{lab} 410$ & 50.5 & 31 & 87 & 2046 & 1,691 & 300 & 5.64 & 3.93 & & & 410h5a \\
\hline$t$ & & lab 410 & 50.5 & 31 & 87 & 2046 & 3,408 & 300 & 11.36 & 9.66 & 8.55 & 2.11 & $410 h 6 t$ \\
\hline a & - & lab 410 & 50.5 & 31 & 87 & 2046 & 2,456 & 300 & 8.19 & 6.48 & & & $410 h 6 a$ \\
\hline$t$ & & lab 401 & 50.5 & 31 & 87 & 2046 & 628 & 300 & 2.09 & 0.39 & 0.17 & 0.04 & $401 \mathrm{~h} 1 \mathrm{t}$ \\
\hline a & & lab 401 & 50.5 & 31 & 87 & 2046 & 667 & 300 & 2.22 & 0.52 & & & $401 \mathrm{~h} 1 \mathrm{a}$ \\
\hline$t$ & & lab 401 & 50.5 & 24 & 87 & 2046 & 722 & 300 & 2.41 & 0.70 & 0.59 & 0.09 & $401 \mathrm{~h} 2 \mathrm{t}$ \\
\hline$a$ & & lab 401 & 50.5 & 24 & 87 & 2046 & 667 & 300 & 2.22 & 0.52 & & & $401 \mathrm{~h} 2 \mathrm{a}$ \\
\hline & $3 / 13 / 96$ & & & & & & & & & & & - & \\
\hline$t$ & & $\operatorname{lab} 406$ & 50.5 & 31 & 87 & 2046 & 2,152 & 300 & 7.17 & 5.47 & 3.04 & 0.75 & $406 \mathrm{~h} 1 \mathrm{t}$ \\
\hline a & & lab 406 & 50.5 & 31 & 87 & 2046 & 2,424 & 300 & 8.08 & 6.38 & & & $406 h 1 a$ \\
\hline$t$ & & lab 406 & 50.5 & 31 & 87 & 2046 & 1,785 & .300 & 5.95 & 4.25 & 2.51 & 0.62 & $406 h 2 t$ \\
\hline $\mathbf{a}$ & & $\operatorname{lab} 406$ & 50.5 & 31 & $87^{\circ}$ & 2046 & 1,929 & 300 & 6.43 & 4.73 & & & $406 \mathrm{~h} 2 \mathrm{a}$ \\
\hline$t$ & & lab 406 & 50.5 & 31 & 87 & 2046 & 2,040 . & 300 & 6.80 & 5.10 & 3.07 & 0.76 & $406 h 4 t$ \\
\hline a & & $\operatorname{lab} 406$ & 50.5 & 31 & 87 & 2046 & 2,188 & 300. & 7.29 & 5.59 & & & 406h4a \\
\hline
\end{tabular}




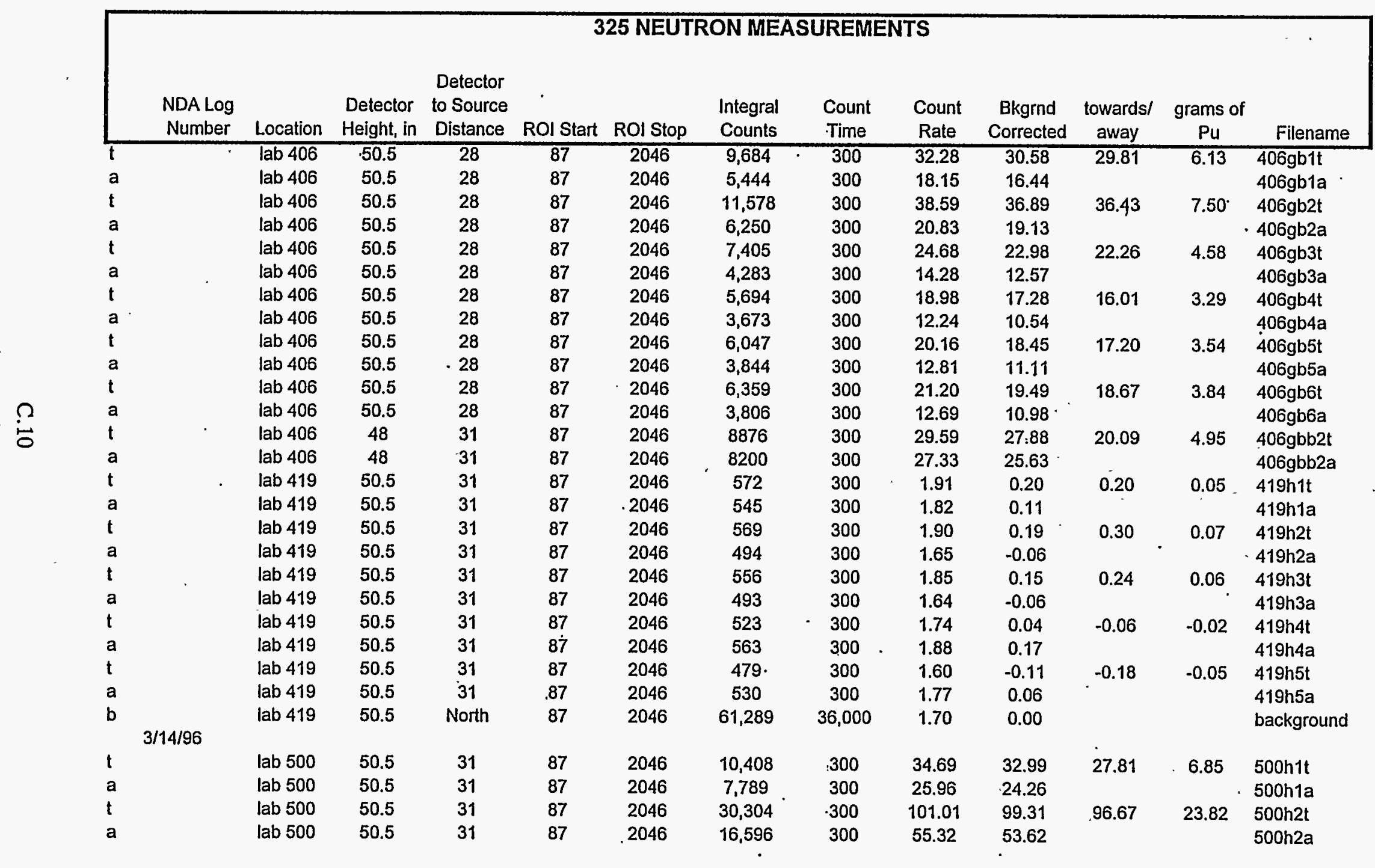




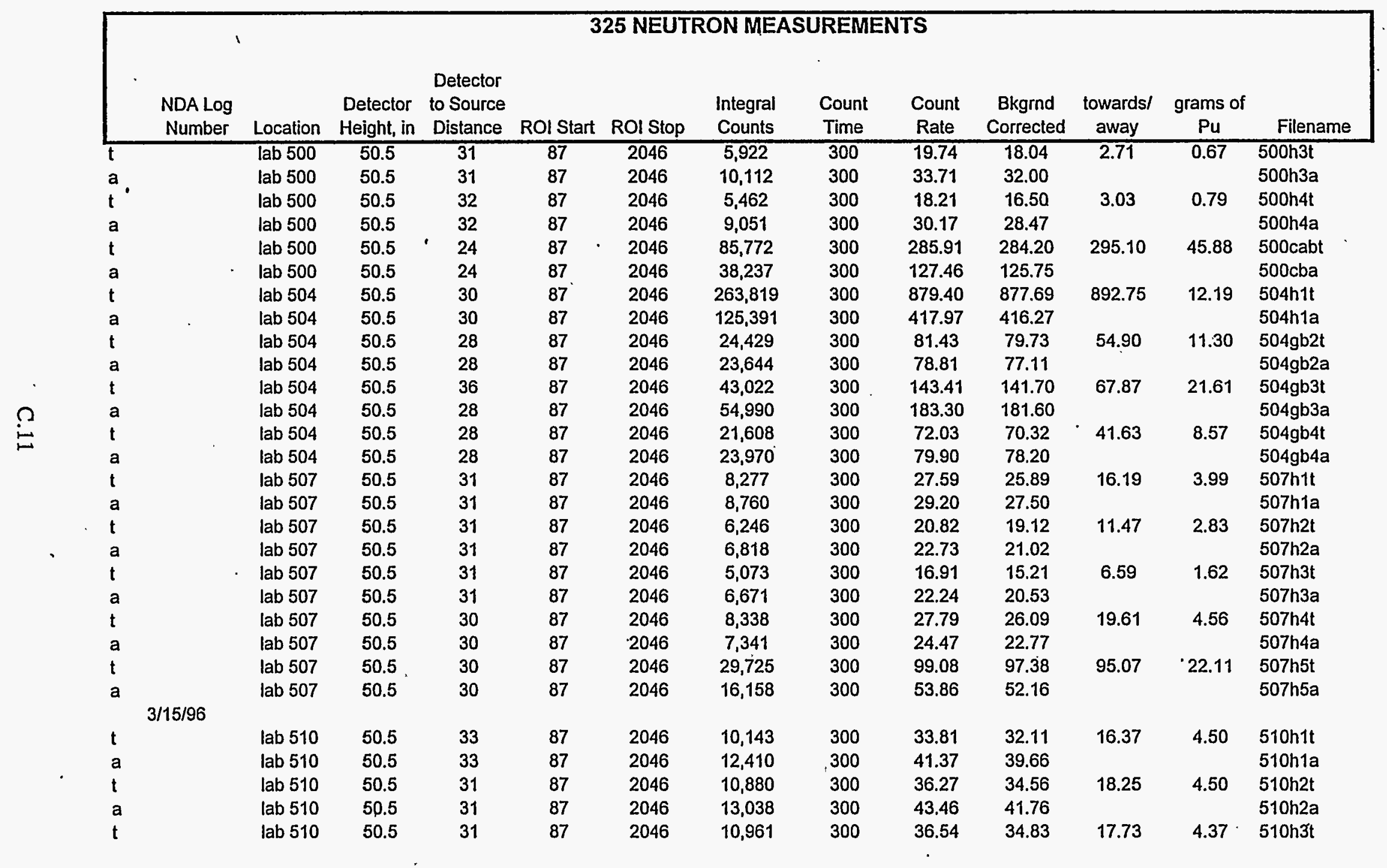




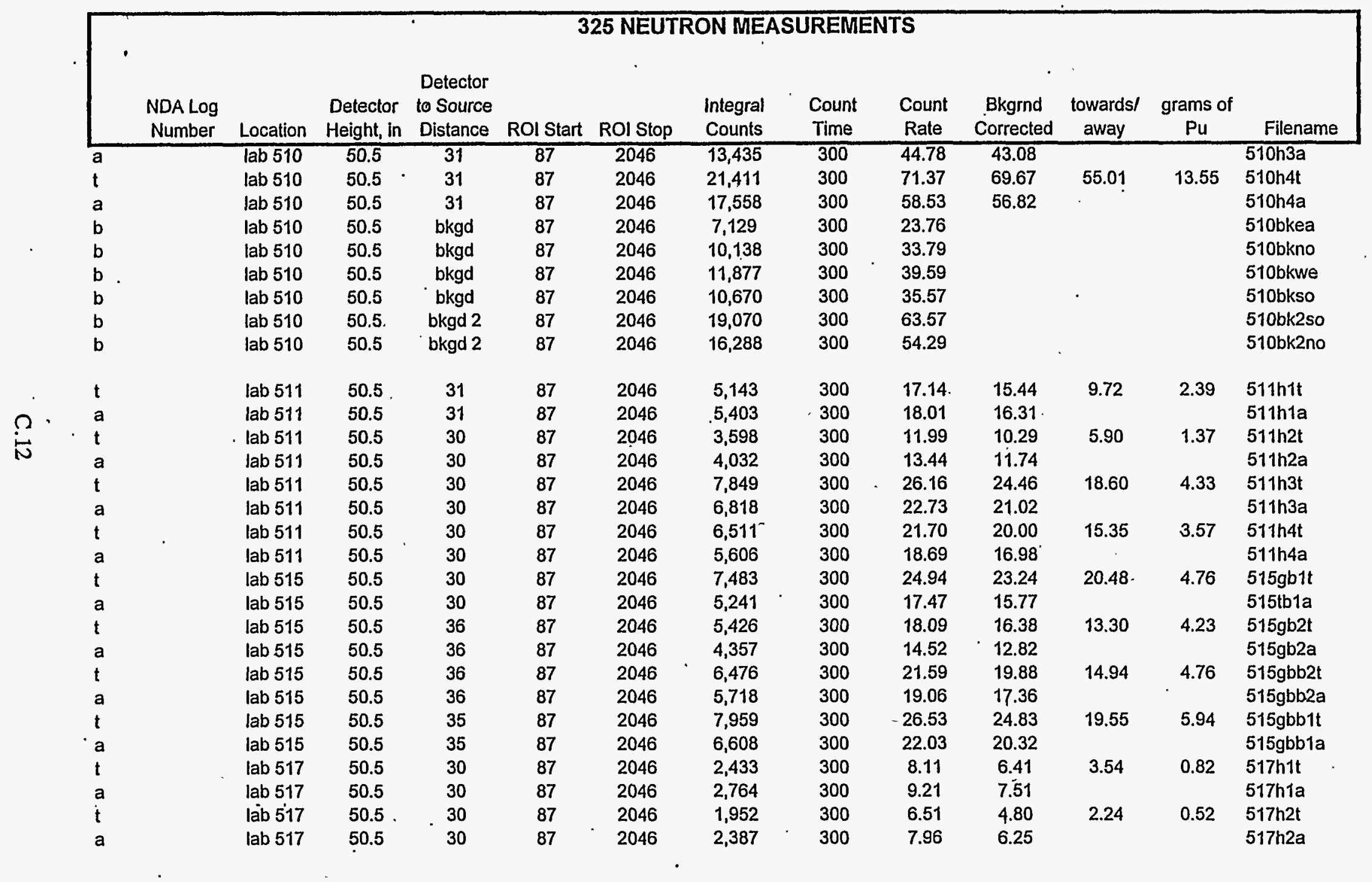




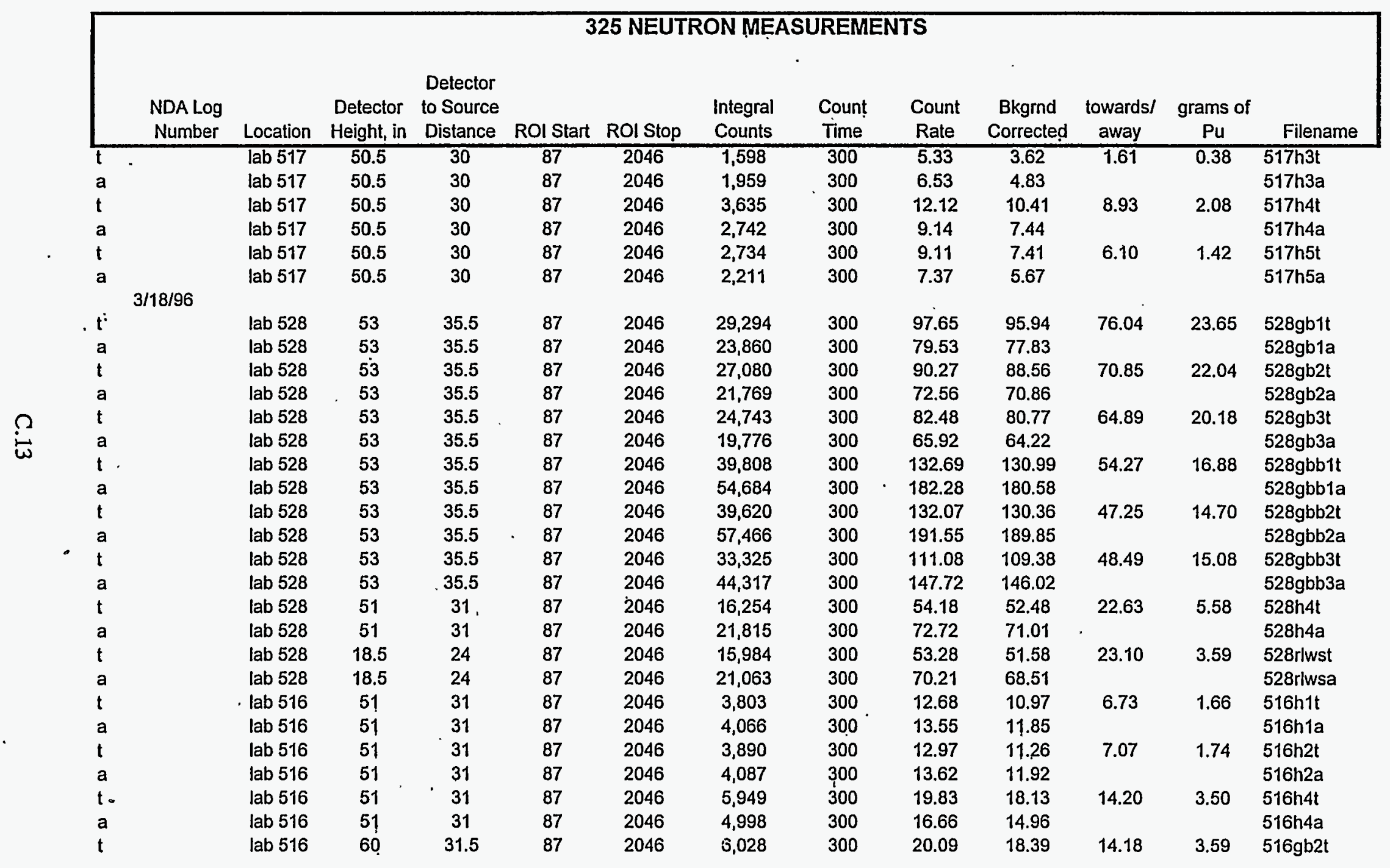




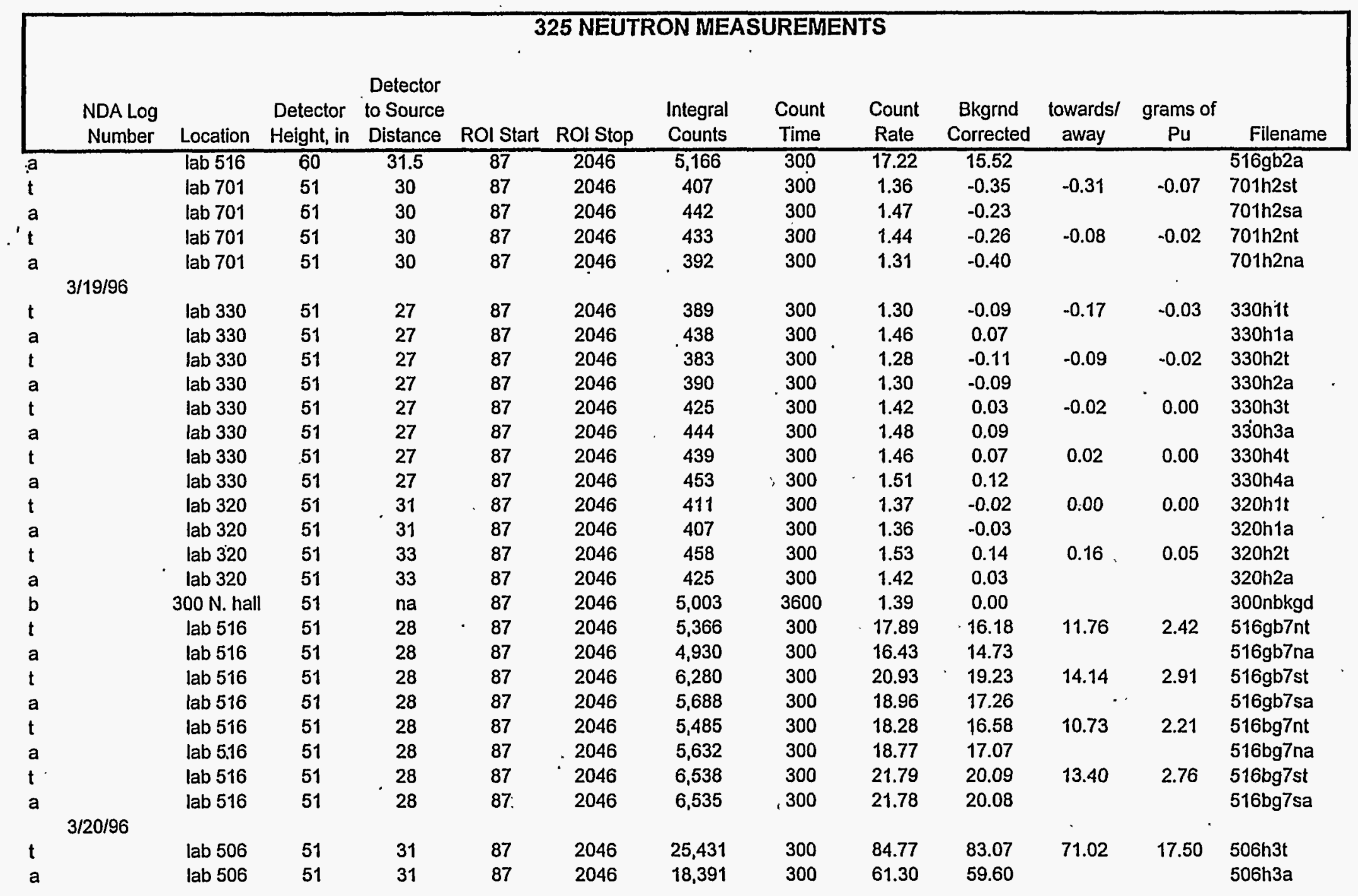




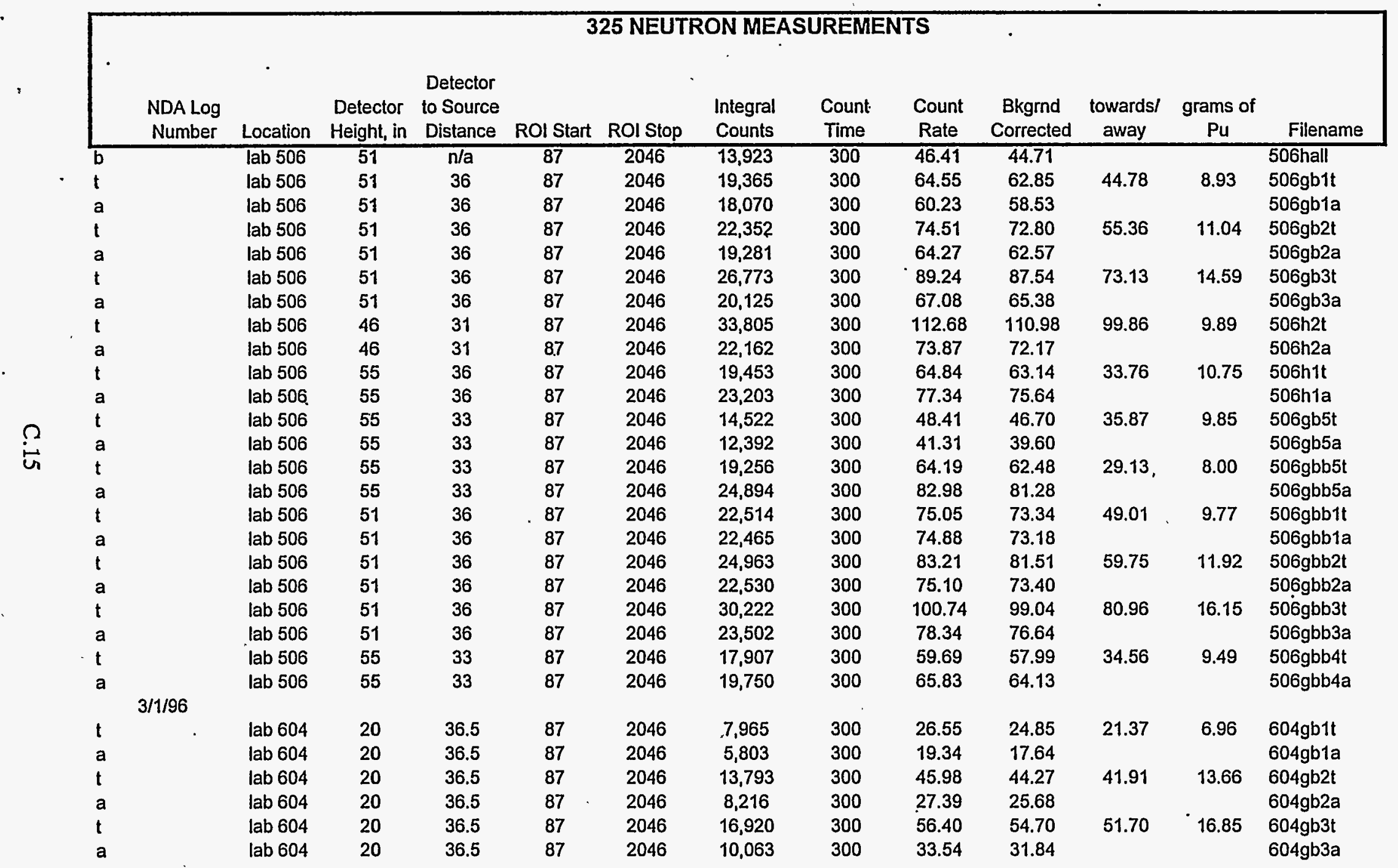




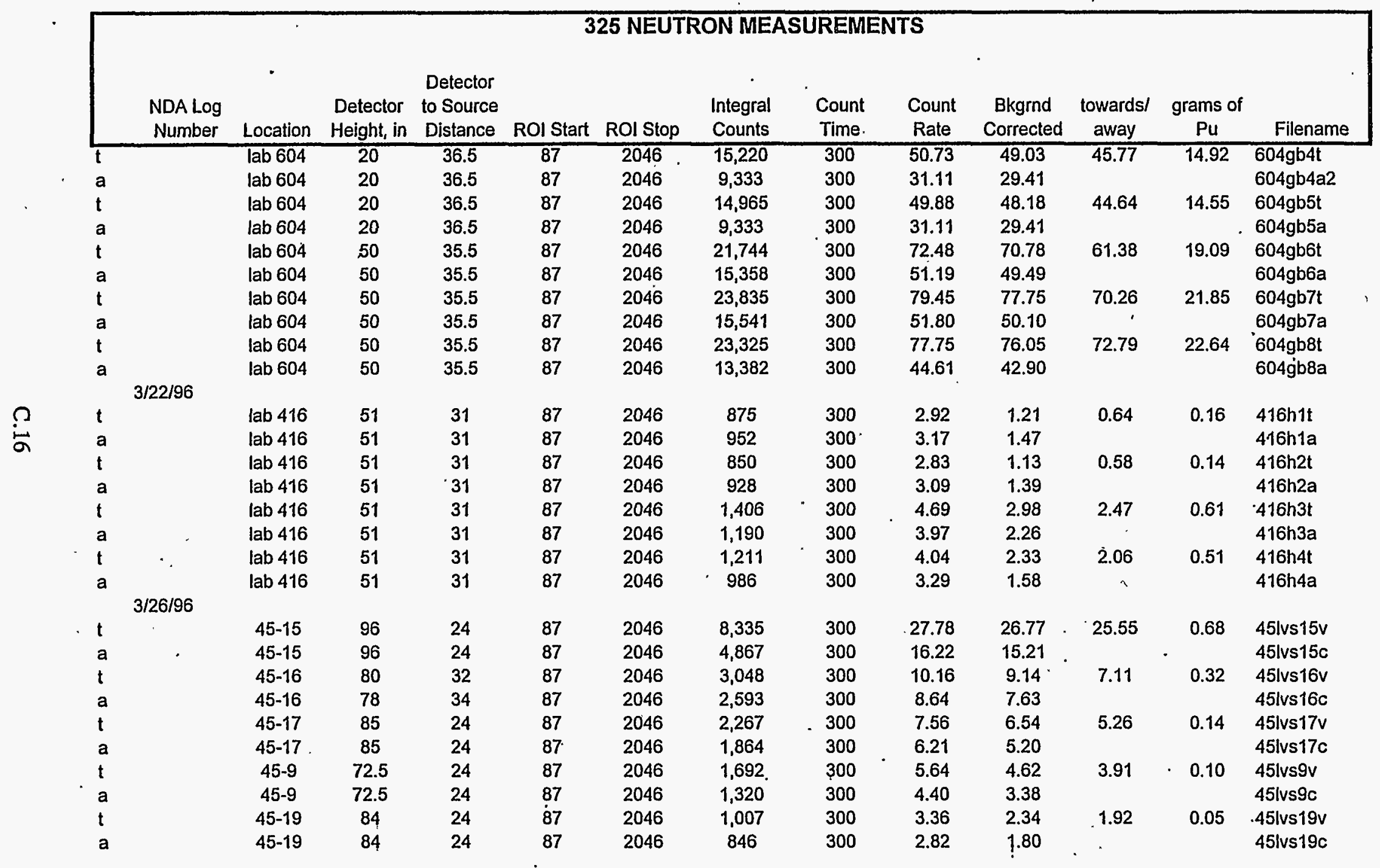




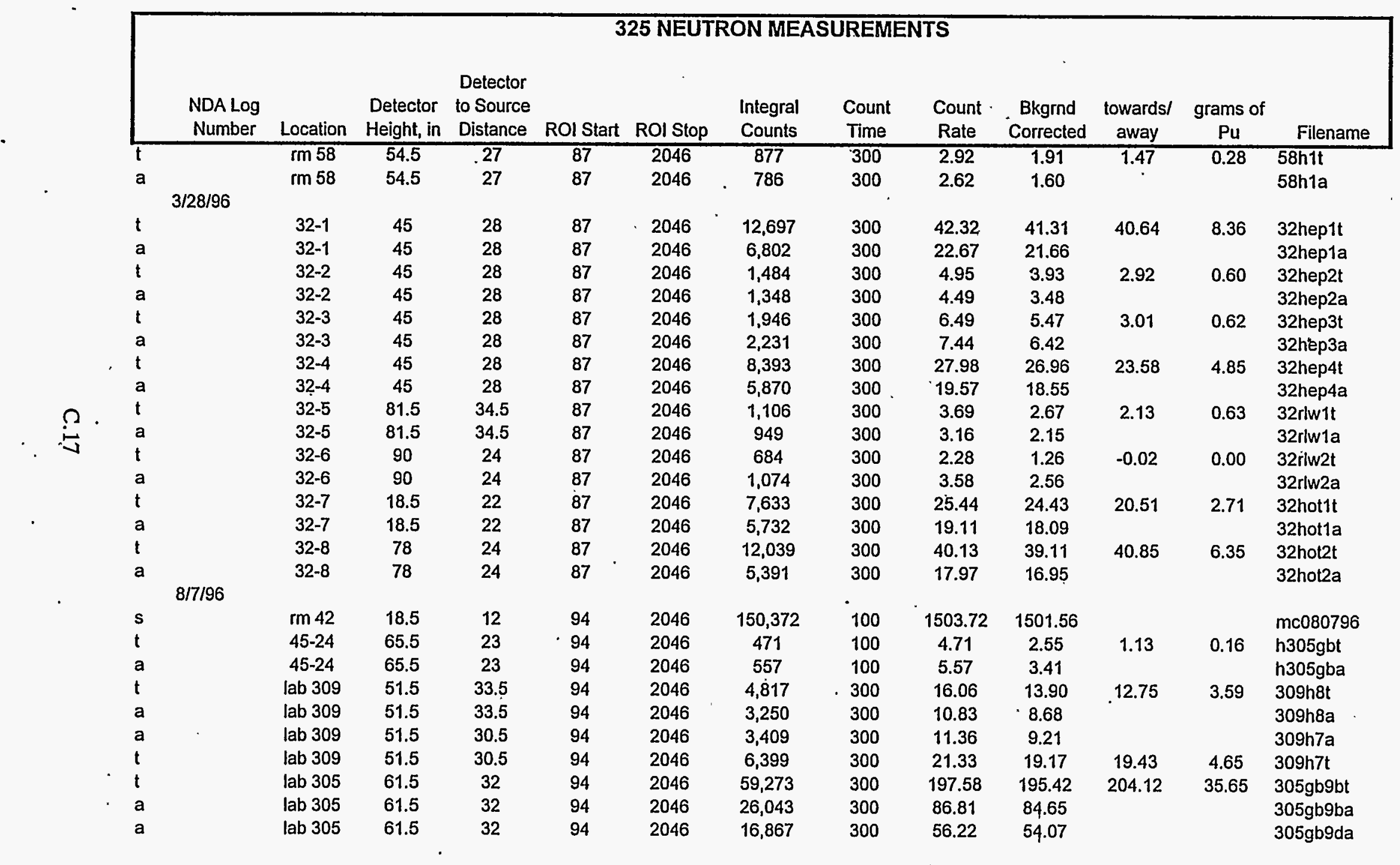




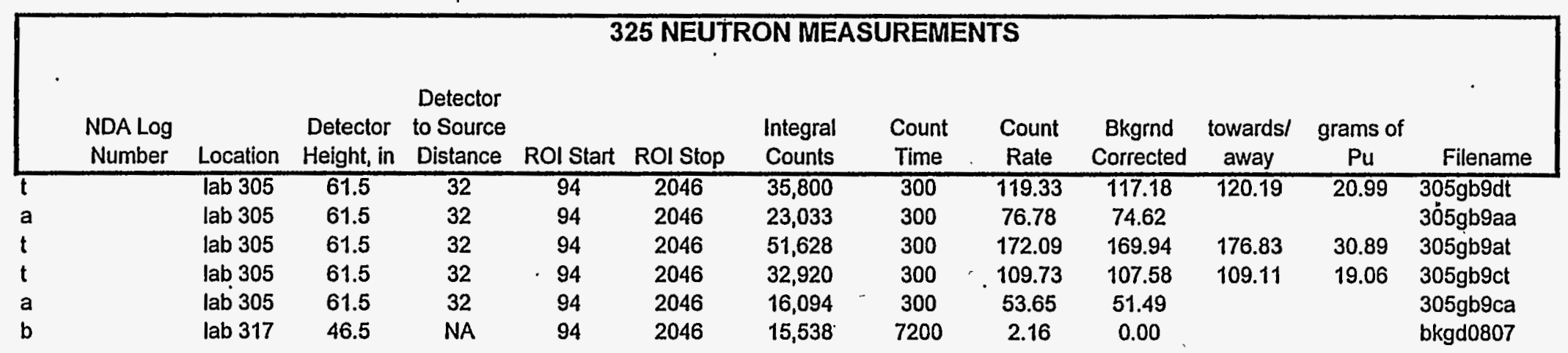

$\stackrel{?}{\infty}$ 


\section{Distribution}

No. of

Copies

ONSITE

DOE Richland Operations Office

'J. E. Trevino

P7-35

23 Pacific Northwest National Laboratory

W. J. Apley

M. J. Bagaglio

P7-75

G. D. Buckley

J. D. Bumgardner

M. Dec

D. L. Haggard (5)

P. J. Gaither
No. of

Copies

S. W. Gority

K6-44

T. M. Graham

P7-79

J. M. Lakovich

P7-27

W. B. Larson

P7-28

D. E. Lucas

P7-35

K. J. Kuhl-Klinger

P7-27

J. D. Rencken

R. D. Scheele

P7-28

P7-25

R. I. Scherpelz

P7-03

P7-22

P7-03

P7-25

J. M. Tingey

P7-03

P. L. Tomeraasen

H. H. Van Tuyl

P7-28

Information Release (7)

Distr.1 